Historic, Archive Document

Do not assume content reflects current scientific knowledge, policies, or practices. 



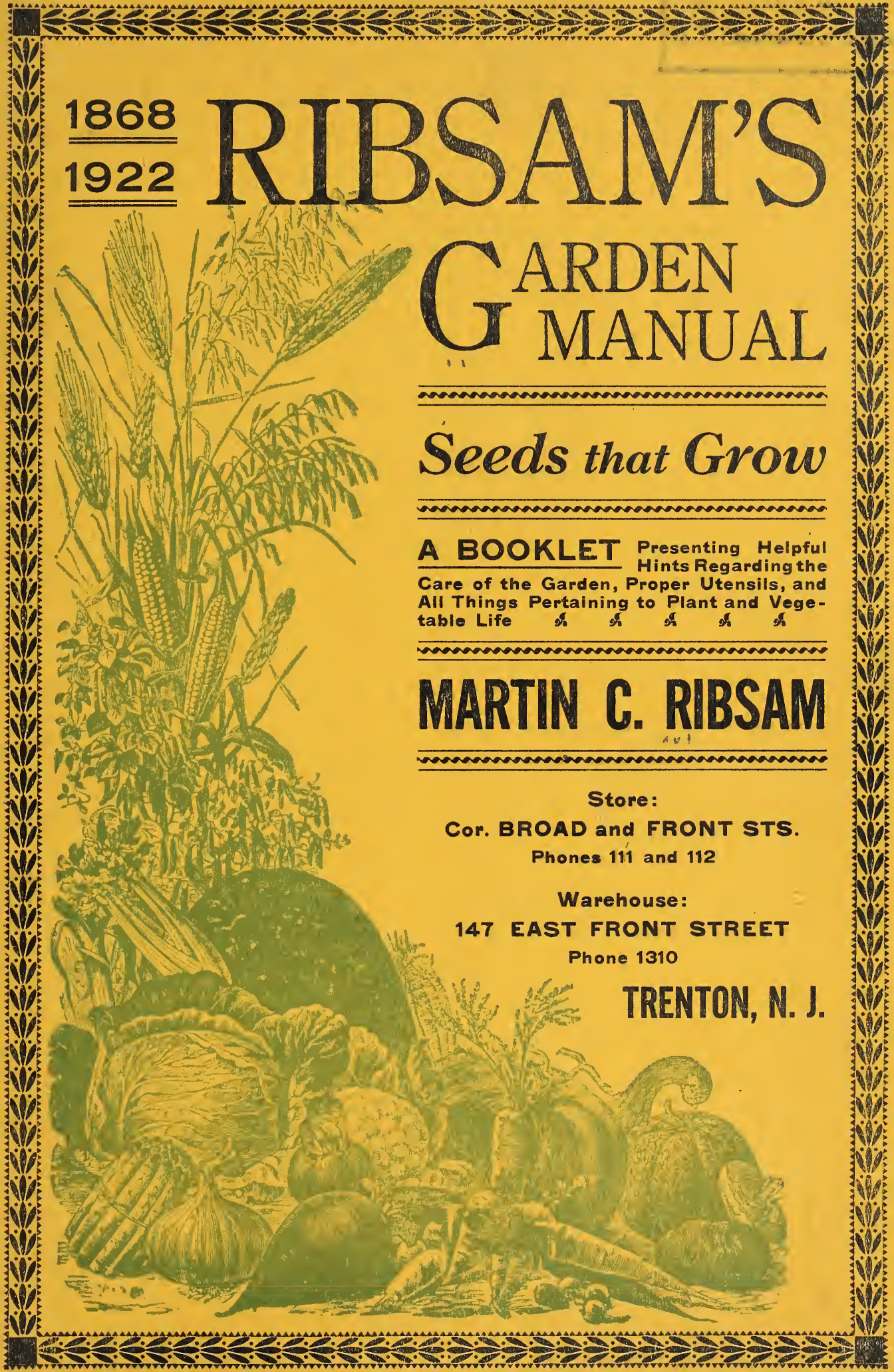




\section{RIBSAM'S MANUAL}

In offering this catalogue we cannot help but harking back over the past fifty-four years and recalling our wonderful growth, due to the confidence of our patrons, won by our constant Hard Work, Good Service, Satisfactory Dealing and Honest Goods. These are the factors which have made our business and kept it growing year by year. This marked advance is a thing we have been working for and aiming at from the beginning, and this success naturally elates one and spurs one on to greater efforts in behalf of his patrons.

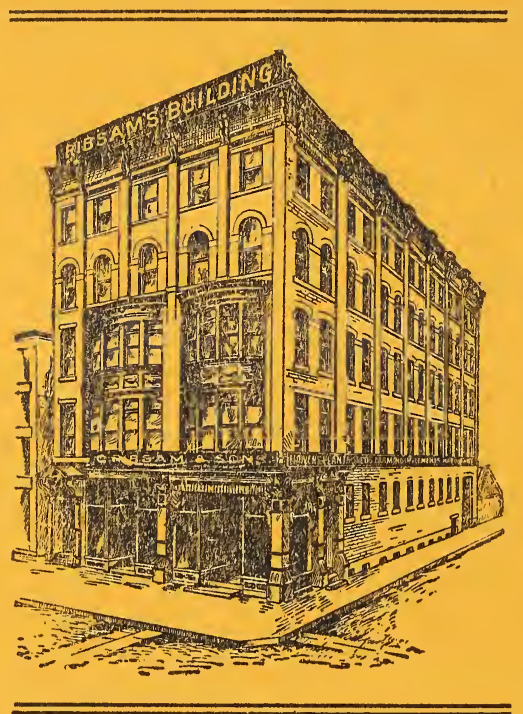

YOUR TRADE.

In soliciting your trade for 1922 I want to thank you for all former orders, and to say that if there is anything $I$ can do to make my service better than it is to-day the same will be done. I solicit your trado on the broad ground of merit and liberal treat. ment. I know this will be the greatest year in the history of my store, and stand ready to give the utmost value possible which will be appreciated by my customers.

\section{The Goods I Sell}

These are the very finest obtainable. When I have found the best seeds, I test them out in my greenhouse and prove them for myself. This makes your buylng so much the surer.

All Seeds are bought direct from the best growers.

All Flowers and Plants are the best Horticulture can produce.

All Trees and Shrubs are selected for their fitness in this climate.

All Implements for the farm and garden are bought from the best manufacturers, who have stood the test of years.

I know they are right before I buy them.

PLEASE NOTE.-While I do all that is possible to procure the best of seeds, I cannot hold myself responsible should any of them fail. I do not wish my customers to buy them under any other understanding. Should they do so, unknowingly, and afterwards wish to return the seeds, whatever money, was paid for them will be cheerfully refunded.

\section{When Ordering}

You will greatly help us by letting us know your wants early.

Add postage for all vegetable seeds of $1 / 4$-pound or more when It is desired to have them forwarded by mail, at the rate of $5 \mathrm{c}$. per $\mathrm{lb}$. and $1 \mathrm{c}$. per $\mathrm{lb}$. for every $\mathrm{lb}$. over for dlstance less than 150 mlles. 1 qt. seed averages 2 lbs.

All seeds by the package or ounce, as per catalogue, I mail wlthout extra charge.

Money may be sent at my risk, WHEN MAILED IN A REGISTERED LETTER, or by post-office order. I allow customers to deduct the cost of drafts or orders from the amount to be remitted when that amount exceeds one dollar. Small sums of one dollar or less may be sent at my risk without registering.

\section{MARTIN C. RIBSAM}

\section{STORE}

Cor. S. Broad and Front Sts.
WAREHOUSE

No. 147 East Front St. 


\title{
RIBSAM'S
}
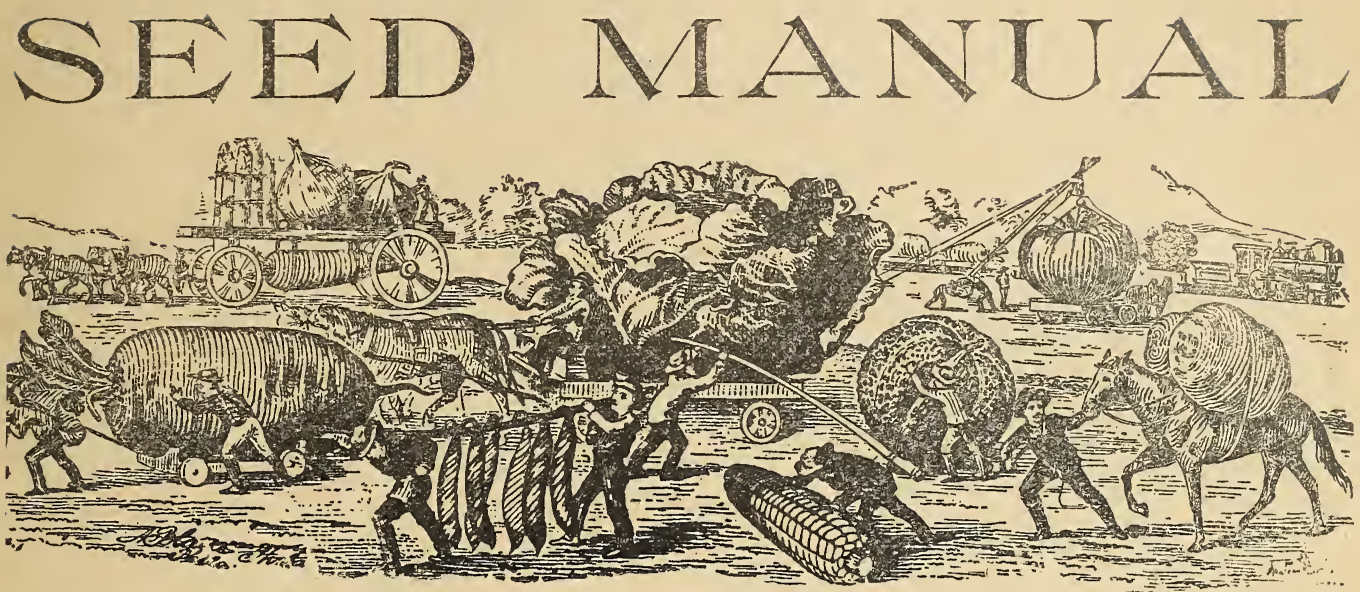

\section{Standard Varieties of Tested Vegetable Seeds FOR THE GARDEN AND FARM WITH DIRECTIONS FOR CULTIVATION}

\begin{abstract}
Wo offer no Novelties, as a large per cent. of those that are offered on the market are worthless. Some few are good old sorts re-named by dashy catalogue writers. We offer only good, tried varieties that are profitable to the Gardener, Trucker and Farmer, excellent in quality and profitable producers.

When ordering seed for Parcel Post delivery add 5c. for first lb. and 1c. for each pound thereafter for distances less than 150 miles.
\end{abstract}

\section{ARTICHOKE.}

One ounce of Artichoke will sow 100 feet of drill and produce about 500 plants.

Sow in April, in rich soil, and transplant the following Spring to permanent beds, in rows (or hills) three feet apart and two feet between the plants. The plantation the first season will only give a partial crop, but as it is a perennial after being once planted the beds will remain in bearing for years. It should be protected in Winter by a covering of leaves or coarse manure.

LARGE GREEN GLOBE, PARIS.-Best for general culture. roc. per pkt.; 50c. per oz.; $\$ 1.75$ per $1 / 4 \mathrm{lb}$. $\$ 6.00$ per $\mathrm{lb}$.

\section{ASPARAGUS.}

One ounce of seed will produce 200 roots and sow about 50 feet of drills. I 100 roots will set $a$ bed $12 \times 40$ feet, which will be large enough for ordinary family. For field culture, plant 5 to 6 feet by $1 \frac{1}{2}$ feet, according to soils.

Sow early in Spring, as soon as the ground will admit of working, in rows 3 feet apart. Keep carefully hoed and clear from weeds and the plants will be in condition to set out the succeeding Spring. The soil for the perma. nent beds should be thoroughly manured, and trenched to a depth of at least two feet. Plant in rows 5 to 6 feet apart, and one and a half feet between the plants in the rows. Spread the roots well out, and let the crown of the plant be covered about six or eight inches when estab. lished.

GIANT ARGENTEUIL or FRENCH.-Most popular variety on account of its large, thick stalks. Very tender, and excellent flavor. 5c. per pkt.; Ioc. per oz.; 20c. per $1 / 4 \mathrm{lb}$.; $65 \mathrm{c}$. per $1 \mathrm{~b}$.

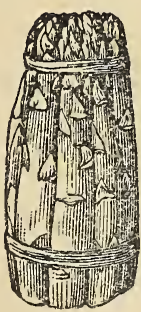

BARR'S MAM MOTH.

BARR'S MAMMOTH.-Has very large tender stalks, of a very light color. 5c. per pkt.; Ioc. per oz.; 20c. per $\mathrm{J} / 4$ lb.; 50c. per $1 \mathrm{~b}$.

COLOSSAL. - The best variety. Unrivaled in size, productiveness and quality. 5c. per pkt.; Ioc. per oz.; $20 \mathrm{C}$ per $\mathrm{r} / 4 \mathrm{lb}$, ; $45 \mathrm{c}$. per $1 \mathrm{~b}$.

COLUMBIA MAMMOTH WHITE.-Stalks large and color white. Very early. 5c. per pkt.; Ioc. per oz.; $20 \mathrm{c}$ per $1 / 4$ lb.; 75 c. per $1 \mathrm{~b}$.

PALMETTO.-This variety is much earlier than Conover's Colossal, a good yielder, and is more even and regular in growth Quality as good as Conover's Colos sal. 5c. per pkt.; Ioc. per oz.; 20c. per $1 / 4$ 1b.; 6oc. per

\section{ASPARAGUS ROOTS.}

GIANT ARGENTEUIL.-Two-year-old roots, \$I.25 per I00; \$10.00 per I,000. 
BARR'S MAMMOTH.-Two-year-old roots, per 100, \$I.25: I,000, \$10.00.

Ask for price on quantities of 5,000 or more roots.

\section{BEANS-English or Broad.}

One pound will plant 100 feet.

This class is very hardy, and should be planted as soon 29 the soil is in good state in the Spring. Plant four inches apart and two inches deep, in drills four feet apart. To insure well-filled pods, pinch off the tops as soon as the lower pods begin to set.

EARLY MAZAGAN.-(Long Pod). Matures in fifty days after germination. $15 \mathrm{c}$. $1 / 4$ lb.; $25 \mathrm{c}$. $1 / 2 \mathrm{lb}$; $45 \mathrm{C}$. Per 1 b. 1b.; 25c. $1 / 2$ 1b.; 45 c. per $1 \mathrm{~b}$.

\section{BEANS-Dwarf or Bush.}

"Sixty pounds to a bushel."

These prices are subject to change without notice.

One pound will plant 50 to 60 feet of drill.

Sixty pound's will seed an acre.

A succession of sowing can be made from the first week in May until the middle part of August. Plant in drills about two inches deep, and from eighteen inches to three feet apart, according to the richness of the soil; the poorer the soil the closer they can be planted. The plants should be about three inches apart.

\section{Green Pod Varieties.}

BOUNTIFUL.-An extra early flat-podded variety, stringless and of fine quality. 20c. per lb.; I $7 \mathrm{c}$. per Io lb. lots; I 5 c. per Ioo 1 b. lots.

FULL MEASURE.-Long, round pod, stringless, very prolific. Pods attractive green color; firm and tender. Plants erect, with dark green foliage, also blight proof. 20c. per $1 \mathrm{~b}$.; I $7 \mathrm{c}$. per Io $1 \mathrm{~b}$. lots; I $5 \mathrm{c}$. per $1 \mathrm{~b}$., Ioo $1 \mathrm{~b}$. lots. EARLY BLACK VALENTINE.-Very popular on account of its extreme hardiness and earliness. Pods long, smooth, round and bright green. They must be picked quick, as they toughen quickly. 20c. per 1b.; 10

EARLY BURPEE STRINGLESS GREEN POD.Very fine quality. Early and strong grower. One of the best round pod sorts. A good picking sort. 2oc. per 1b.; Io lb. lots, I $7 \mathrm{c}$. per lb.; I $5 \mathrm{c}$. per lb. in Ioo $1 \mathrm{~b}$. lots.

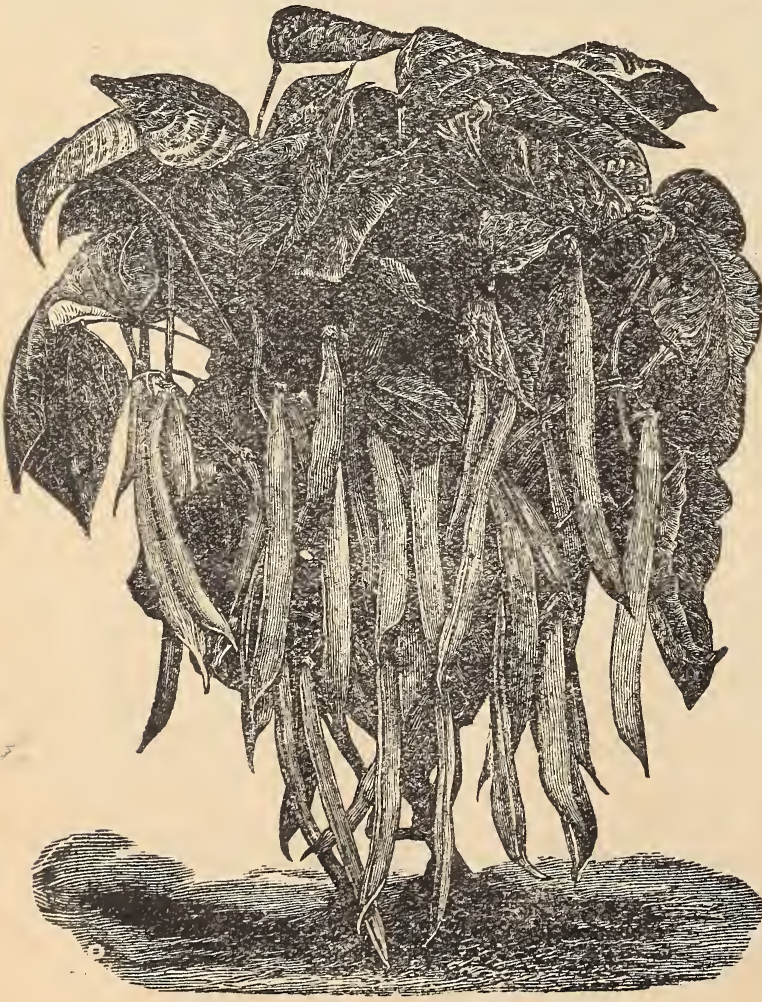

PENCIL, POD WAX.
THE GIANT PODDED STRINGLESS VALENTINE.-Distinctly superior to its parent the Early Red Valentine. The pods are borne in enormous quantities close to the center of the plant, and are not only longer but much thicker and more meaty than any of this string. less type. $20 \mathrm{c}$. per lb.; ro $1 \mathrm{~b}$. lots, I7c. per 1b.; I $5 \mathrm{c}$. per $1 \mathrm{~b}$. in $100 \mathrm{lb}$. lots.

EARIY IMPROVED RED VALENTINE,-Early, productive, tender, succulent and excellent fiavor. Continues longer in the green state than most of the varie. ties. 2oc. per lb.; Io lb. lots, I7c. per 1b.; I5c. per lb. in $100 \mathrm{lb}$. lots.

EARLY IMPROVED REFUGEE,-Same as the above, but earlier. 20c. per 1b.; Io lb. lots, I7c. per lb.; I5c.

EARLY LONG YELLOW SIX WEEKS.-Early and prolific. An excellent variety for general crop. 20c. per ib.; Io $1 \mathrm{~b}$. lots, I7c. per $1 \mathrm{~b}$.

LATE REFUGEE, I,000 to I.-Late; very productive, tender and large. Grown for main crop. Round pod. 20c. per 1b.; Io $1 \mathrm{~b}$. lots, I7c. per 1b.; I5c. per 1b. in 10. lots.

LARGE WHITE KIDNEY.-Excellent as a shell bean, green or ripe. $25 \mathrm{c}$. per $1 \mathrm{~b}$; io $1 \mathrm{~b}$. lots, I7c. per $1 \mathrm{~b}$.

IWHITE MARROWFAT.-Extensively grown for sale in the dry state; of average quality as a string bean, but excellent shelled, either green or dry. 20c. per lb.; Io $1 \mathrm{~b}$. lots, $17 \mathrm{c}$. per $1 \mathrm{~b}$.

WHITE NAVY.-Small round white winter bean. $20 \mathrm{c}$. per $1 \mathrm{~b}$; i 5 lb. lots, I $7 \mathrm{c}$. per $1 \mathrm{~b}$.

\section{BUSH LIMA.}

60 pounds to a bushel.

FORDHOOK BUSH LIMA.-Best market variety of the bush sort. The beans are thick, of large size, and fine quality. Very prolific. Ioc. $1 / 4$ lb.; 30c. er $1 \mathrm{~b}$.; Io $1 \mathrm{~b}$. lots, 23c. per lb.; I0o lb. lots, 22c. per lb.

BURPEE'S BUSH LIMA.-The true bush form of the Large Lima Pole Bean. Beans nearly the size of Pole Limas. Ioc. $1 / 4$ lb.; 3oc. per lb.; 10 1b. lots, $23 \mathrm{c}$.

DREER'S BUSH IIMA.-The best variety of the Bush Lima sort for home garden. Pods well filled and quality of bean unexcelled. Ioc. $1 / 4 \mathrm{lb}$; 30c. per $1 \mathrm{~b}$; Io 1b. lots, 25c. per 1b.

HENDERSON'S BUSH LIMA.-Produces enormous crops of delicious small LIMA BEANS, which can be a easily gatliered as the common garden Bush Bean. It is at least two weeks earlier than any of the climbing Limas. Ioc. $1 / 4$ lb.; $25 \mathrm{c}$. per $1 \mathrm{~b}$; ; Io $1 \mathrm{~b}$. lots, 30c. per $1 \mathrm{~b}$.

IMPROVED BURPEE'S BUSH LIMA.-Larger is size of pods. Bean thicker; green in color, and quality good. Improvement on Burpee Bush Limas. I oc. $1 / 4 \mathrm{lb}$; 3oc. per lb.; Io $1 \mathrm{~b}$. lots, 23c. per lb.; I0o lb. lots, 22c. per

\section{WAX OR YELLOW-Podded Varletles.}

60 pounds to a bushel.

BURPEE KIDNEY WAX.-Plants erect, grows 18 to 20 inches, free from blight and rust. Pods lemon yellow, semi-round, stringless, 6 to 7 inches long and bear twice as many as Wardwell's and yields at the same time. Shows up beautifully in basket. $25 \mathrm{c}$. per $1 \mathrm{~b}$; ; $10 \mathrm{lb}$. lots, 2oc. per 1b.; I8c. in I0o lb. lots.

BLACK WAX OR BUTTER.-The pods, when ripe, are of a waxy yellow, transparent, very tender and delicious. An excellent variety. 25c. per lb.; Io lb. lots, 20c. per 1b.; I6c. in I0o $1 \mathrm{~b}$. lots.

CURRIE'S RUST-PROOF BLACK WAX.-Pods long flat and straight, of a beautiful golden color. Quality not surpassed, and for productiveness, unequalled. $25 \mathrm{c}$, per 1b.; Io $1 \mathrm{~b}$. lots, I8c. per $1 \mathrm{~b}$; I6c. per $1 \mathrm{~b}$, in $100 \mathrm{w}$. lots.

HODSON WAX.-An abundant bearer of bright yellow round pods. The plants make a strong growth, are healthy and rust-proof. ${ }^{25} \mathrm{c}$. per $1 \mathrm{~b}$.; ro lb. lots, 2øc. per lb.; I8c. in Ioo $\mathrm{lb}$. lots.

DAVIS KIDNEY WAX.-A white seeded Wax Bean; long oval pods. One of the best for private use. $25 \mathrm{c}$. per $1 \mathrm{~b}$.; Io $1 \mathrm{~b}$. lots, 18c. per $1 \mathrm{~b}$.

GOLDEN-EYED WAX.-Very hardy and prolific, with fat, yellow pods. Very early and exceptionally free from rust. A very desirable and popular sort. $25 \mathrm{c}$. per $1 \mathrm{~b}$.; ro $1 \mathrm{~b}$. lots, 2oc. per $1 \mathrm{~b}$.

IMPROVED GOLDEN WAX.-A flat-podded sort, but probably the best known of the yellow wax pod varieties, having become everywhere popular because of its long, showy pods, which are nearly twice the length of the old Black-Seeded Wax. 25c. per 1b.; 10 1b. lots, 20c. per 1b.; I8c. I0o lb. lots. 
KEENEY'S RUSTLESS ROUND POD WAX.-One of the best Early Round Pod varieties. 25c. per lb.; Io lb. lots, 20c. per lb.; I8c. Ioo lb. lots.

PENCIL POD WAX.-Pods are long, straight, round like a pencil; fleshy, of a bright yellow color, tender, brittle and absolutely stringless; very productive. $25 \mathrm{c}$. per $1 \mathrm{~b}$.; Io lb. lots, 20c. per lb; ; I c. per lb. Ioo lb. lots.

REFUGEE WAX.-This is a valuable sort for early and late sowing. It withstands drought better than any other wax bean. Pods round, very tender, of a waxy, yellow color, very productive. 25c. per lb.; ro lb. lots, 20c. per lb.; I $6 \mathrm{c}$. pér $1 \mathrm{~b}$. I $00 \mathrm{lb}$. lots.

WARDWELI'S RUST-PROOF KIDNEY WAX.This bean is remarkably free of rust. Pods long, broad

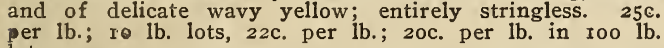
lots.

ROUND POD KIDNEY WAX.-A vigorous grower, pods fleshy, stringless and rust-proof. 25c. per lb.; Io lb. lots, 20c. per lb.; I8c. per lb. I0o lb. lots.

\section{BEANS-Pole or Running.}

60 pounds to a bushel.

One pound will plant about so hills.

These are more tender and require rather more care in the culture than the bush beans, and should be sown two weeks later than those; they succeed best in sandy loam, which should be iiberally enriched with short ma. nure in the hills, which are formed, according to the vari. ety, from three to four feet apart; from five to six seeds are planted in each hill, about two inches deep.

OLD HOMESTEAD or KENTUCKY WONDER.Very early and enormously productive, long green pods, hanging in clusters on the poles, are stringless and cook tender. Ioc. $1 / 4$ lb.; $25 \mathrm{c}$. per lb.

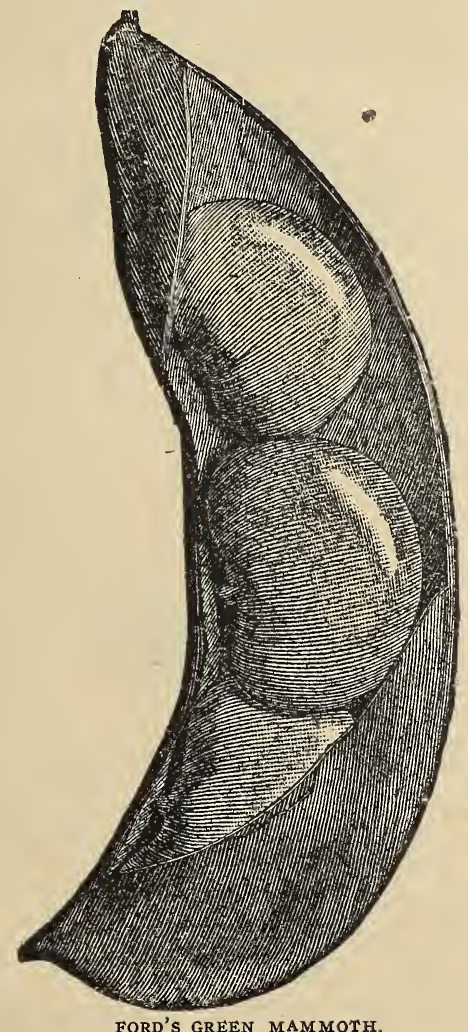

EARLY GOLDEN CLUSTER POLE WAX.-The Early Golden Cluster begins to bear early in July and continues until frost. The pods are from six to eight inches long, and are borne in clusters of from three to inches long, and are borne in clusters of from three to six, and are most freely produced. The pods are of a licious. This variety can be used either shelled or as a string bean. Ioc. $1 / 4 \mathrm{lb}$; $30 \mathrm{c}$. per $1 \mathrm{~b}$.
DUTCH CASE KNIFE.-A very productive variety, and one of the earliest; sometimes used as "snap," but generally shelled. roc. $1 / 4 \mathrm{lb}$; $35 \mathrm{c}$. per $\mathrm{lb}$.

LAZY WIFE'S POLE BEAN.-The pod grows from six to eight inches long, entirely stringless and of a rich buttery flavor when cooked. Ioc. $1 / 4 \mathrm{lb}$; ; 3oc. per $\mathrm{lb}$.

WHITE CREASBACK.-Long green pod, snap short: very tender; pods attractive and prolific; grow five to six inches in length. IOc. $1 / 4 \mathrm{lb}$; 3 oc. per $1 \mathrm{~b}$.

SCARLET RUNNER.-A great favorite in European gardens, both as an ornamental plant and a useful vegetable. It grows to the height of ten feet, producing dazzling scarlet flowers. Ioc. $1 / 4 \mathrm{lb}$; ; 30c. per $1 \mathrm{~b}$.

\section{BEANS, POLE LIMA.}

60 pounds to a bushel.

DREER'S IMPROVED POTATO OR CHALLENGER. - Earlier and more prolific than large lima. Bean smali and of extra quality, thick. Produces almost all season. Ioc. per $1 / 4 \mathrm{lb}$; 30c. per lb.; Io lb. lots, 22c. per lb.; I $00 \mathrm{lb}$. lots, 20c. per $\mathrm{lb}$.

FORD'S GREEN MAMMOTH.-This is undoubtedly the best of all the climbing Limas, the individual beans being of enormous size, containing from five to eight Green Beans to a pod. Ioc. $1 / 4$ lb.; 30c. per lb.; Io $1 \mathrm{~b}$. lots, 25c. per lb.; roo lb. lots, 20c. per lb.

LEVIATHAN EARL, Y.-An exceedingly early and an enormous cropper from the start; quality fine. Ioc. $1 / 4$ lb.; 3oc. per lb.; 10 lb. lots, 22c. per lb.; I0o lb. lots, 20c. per lb.

CARPINTERIA.-A variety that retains its green color at all times, even after drying. It has a very fine flavor and size and is very prolific. It is a good early variety. The seed is broad and thick. Ioc. $1 / 4 \mathrm{lb}$; $30 \mathrm{oc}$ per lb.; 1o lb. lots, 22c. per lb.; roo lb. lots, $20 \mathrm{c}$. per lb.

KING OF THE GARDEN.-Large in pod, and bean very productive. Ioc. $1 / 4 \mathrm{lb}$; 30c. per lb.; Io lb. lots, 22c. per lb.

SIEBERT'S EARLY.-An improvement on the large lima bean, the pods being peculiarly thin and flexible so that they are more easily opened and shelled than other beans. When in condition for use they are larger than any other variety and very handsome in shape and color. It is the earliest of the large limas. Vines are hardy and very productive; a trial will be well rewarded. I oc. $1 / 4 \mathrm{lb}$; 30c. per lb.; Io $\mathrm{lb}$. lots, $22 \mathrm{c}$. per lb.

\section{BEET.}

One ounce of garden varieties will sow 75 feet of drill 5 to 6 pounds to the acre.

The soil which is best suited for the culture of the Beet is that which is rather light than otherwise, always pro. vided that it is thoroughly enriched with manure. For in early supply sow in Spring, as soon as the ground becomes fit to work, in drills about one foot apart and two inches deep. For main crop sow the frret week in May, and for Winter use sow in June. When the plants have attained three or four leaves, thin out, so that they may stand eight or nine inches apart. Keep free from weeds by hand-weeding and hoeing. In October the roots may be taken up and stored, care being taken that they are not bruised or injured in the process.

NUTTINGS EARLY GEM.-For early beet this is one of the best. Will grow well under sash. It is smooth and dark in color with small tops. An excellent all season variety. 5c. per pkt.; Ioc, per oz.; 35c. per 1/4 lb.; $\$ 1.00$ per $\mathrm{lb}$.

EARLY EGYPTIAN TURNIP, CROSBY IMP. AMERICAN STRAIN.-Earliest beet in cultivation. Color, deep crimson. Of excellent quality. 5c. per plkt; Ioc. per oz.; $25 \mathrm{c}$. per $1 / 4 \mathrm{lb}$; $75 \mathrm{c}$. per $1 \mathrm{~b}$.

EARLY EGYPTIAN DARK RED.-The old standard sort. 5c. per pkt.; roc. per oz.; 25 c. per $1 / 4$ lb.; $75 \mathrm{c}$. per lb. ECLIPSE-While it is just about as early as the Egyptian, it is better, because it is larger and of much finer quality. It makes a small top, and produces smoothgrowing, perfectly round Beets, the skin and flesh of which are of dark crimson color. 5c. per pkt.; roc. per oz.; $25 \mathrm{c}$. per $1 / 4 \mathrm{lb}$; $65 \mathrm{c}$. per lb.

CRIMSON GLOBE.-Handsome second early main crop market sort. 5c. per pkt.; Ioc. per oz.; $25 \mathrm{c}$. per $1 / 4$ lb.; $65 \mathrm{c}$. per $\mathrm{lb}$.

EARLY LENTZ'S BLOOD TURNIP. - It has a very small top, and will produce a crop in six weeks from the time of planting the seed. It is very productive and perfect keeper. $5 \mathrm{c}$. per pkt.; roc. per oz.; $25 \mathrm{c}$. per $3 / 4$ lb.; 75 c. per $1 \mathrm{~b}$. 


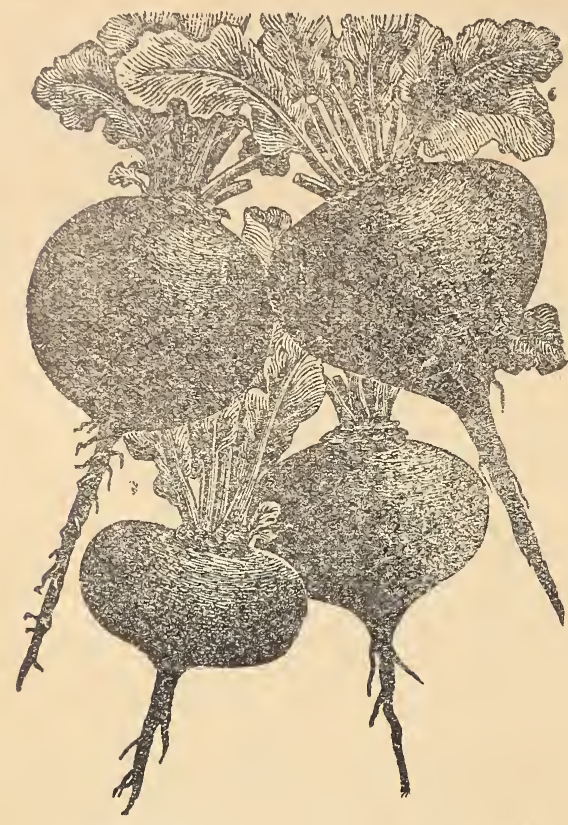

CRIMSON GLOBE.

BASTIAN BLOOD TURNIP.
EARLY LENTZ. CROSBY'S EGYPTIAN.

BASTIAN'S BLOOD TURNIP.-After the Egyptian Turnip, probably the earliest variety of Beet. Is of blood-red color, when boiled. 5c. per pkt.; I oc. per oz.; 25c. per $1 / 4 \mathrm{lb}$; $75 \mathrm{c}$. per $1 \mathrm{~b}$.

EARLY BLOOD TURNIP.-The standard early sort. An excellent variety. 5c. per pkt.; Ioc. per oz.; $25 \mathrm{c}$. per $1 / 4 \mathrm{lb}$; $75 \mathrm{c}$. per $1 \mathrm{~b}$.

LONG SMOOTH BLOOD-RED.-An excellent late variety. A great improvement on the common Long Blood. 5c. per pkt.; 10c. per oz.; $25 \mathrm{c}$. per $1 / 4 \mathrm{lb}$; $65 \mathrm{c}$. per lb.

DETROIT DARK RED-One of the best market gardener's variety. It is early, fine grained; remains tender longer than any other variety. 5c. per pkt.; roc. per oz.; 25c. per $1 / 41 \mathrm{lb}$; $75 \mathrm{c}$. per $1 \mathrm{~b}$.

SWISS CHARD, SILVER OR SEA KALE-Thi variety is cultivated solely for its leaves. The mid-rib is stewed and served as asparagus, the other portions of the leaf being used as spinach. If often cut, new and more tender leaves will be reproduced. 5c. per pkt.; roc. per oz.; $25 \mathrm{c}$. per $1 / 4 \mathrm{lb}$; ; $75 \mathrm{c}$. per $1 \mathrm{~b}$.

GIANT LUCULLIAS.-Curled. 5c. per pkt.; roc. per oz.; $25 \mathrm{c}$. per $1 / 4 \mathrm{lb}$; $75 \mathrm{c}$. per lb.

HALF LONG.-The principail points of excellence in the Half Long as distinguished from the round varietiea are the vividly rich colors which characterize almost every long variety, and their peculiar adaptation for slicing, while its extreme tenderness and freedom from a rooty fibre will make it one of the leading late Winter sorts. 5c. per pkt.; Ioc, per oz.; 25c. per $1 / 4$ lb.; $7.5 \mathrm{c}$. per $1 \mathrm{~b}$.

WHITE SUGAR.-Good for late table and stock feed. ing; very sweet. roc. per 0z.; 20c. per $1 / 4 \mathrm{lb}$; $50 \mathrm{cc}$ per lb.

\section{MANGEL WURZEL AND SUGAR BEET.}

The following varieties are grown for feeding cattle and stock. Sow in April or May. Six to eight pounds per acre, in rows three feet apart, thin out to six inches in the row. During rainy weather the plants can be trans. planted.

MAMMOTH LONG RED.-This is the finest stock of Long Red Mangel in cultivation. Ioc. per oz.; 20c. per $1 / 4 \mathrm{lb}$; $45 \mathrm{c}$. per $1 \mathrm{~b}$

GOLDEN TANKARD.-This variety is an exceedingly popular variety in Great Britain, where it is considered particularly valuable on account of its nutritious and milk-producing qualities. Sheep have preference for this sort over other mangels. It is said that they will pict

out every piece of Golden Tankard before touching others. It yields, under the best cultivation, 75 tons per acre Ioc. per oz.; $20 \mathrm{c}$. per $1 / 4 \mathrm{lb}$; $45 \mathrm{c}$. per $1 \mathrm{~b}$.

RED GLOBE.-A variety similar to the Yellow Globe in shape and size, and differing only in color. Ioc. per oz.; 20c. per $1 / 4$ lb.; 45 c. per lb.

YELLOW GLOBE.-Roots of large size and globular form. Very productive. Keeps better than the Long Red, and is better adapted for growing in shallow soil. roc. per oz,; 20c. per $1 / 4$ lb.; 45 c. per $1 \mathrm{~b}$.

\section{BROCCOLI.}

One ounce will sow 75 feet of drill, and produce about 2,000 plants.

Nearly allied to the Caulifiower, but more hardy; the seed should be sown in this district in the early part of May and transplanted in June; farther south the sowing should be delayed until June or July, and the transplanting accordingly, from August to October. In parts of the country where the thermometer does not fall below 20 to 25 degrees, Broccoli may be had in perfection from November until March. It succeeds best in a moist and rather cool atmosphere.

WHITE CAPE.-Heads medium size, close, compact, and of a creamy white color. One of the most certain to head. Ioc. per pkt.; 75 c. per oz.; $\$ 3.00$ per $1 / 4 \mathrm{lb}$.; $\$ 10.00$ per lb.

PURPLE CAPE.-Differs only in color. roc. per pkt. 65 c. per oz.; $\$ 2.00$ per $1 / 4 \mathrm{lb}$.; $\$ 6.00$ per $1 \mathrm{~b}$.

\section{BRUSSELS SPROUTS.}

One ounce will sow 75 feet of drill, and produce about 2,000 plants.

This is one of the best vegetables for Winter use, producing from the axils of the leaves an abundance of sprouts, resembling small cabbages, of excellent, mild flavor. It has never come into general use in this country, probably owing to its being too tender to stand

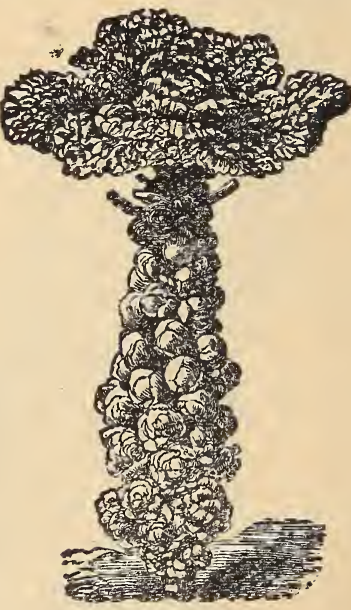

TALL FRENCH.

the Winters of the Northern States; still, by sowing in April or May, and planting out in July, it may be had in fine condition until December, and in the Southern States may be had in use from November to March.

DWARF IMPROVED.-A variety producting compact sprouts. Ioc. per pkt.; 2oc. per oz.; 65c. per $3 / 4$ lb.; $\$ 2.00$ per $1 \mathrm{~b}$.

TALL FRENCH.-Very fine. roc. per pkt.; $25 \mathrm{c}$. per oz.; 75c. per $1 / 4 \mathrm{lb}$; $\$ 2.50$ per lb.

\section{CABBAGE.}

One ounce will sow 75 feet of drill, and produce about 2,000 plants.

The early varieties of Cabbage are cuitivated more extensively than any other vegetable. In latitudes where the thermometer never indicates 20 degrees below the the thermometer never indicates 20 degrees below the
freezing point, seed may be sown in the open border in October, and planted out on the first opening of Spring, but in our Northern States they must either be sown in hot-beds in February, or, what is still better, wintered over in cold-frames. For this purpose the seed is sown 
from the roth to the 2oth of September. Attention to date is important; if too soon, the plants might run to seed, and if too late, they will be too small. In four or five weeks from the time of sowing they will be fit to transplant into cold frames. In planting it is very important with Cabbage or Cauliflower that the plant is set down to the first leaf so that the stem is all under ground, for if exposed, it will be split by the action of the ground, for if exposed, and will be injured in consequence. The plants are usually set out from the midule of March to the middle of April, in row's about two feet apart, and eighteen inches between the plants in rows. The late varieties are usually sown in the early part of May, and the plants are set out in July, at a distance of three feet between the rows and two feet between the plants.

CHINESE OR PTE-SAI.-It is called cut cabbage in China, and is appearing extensively in our markets. It grows erect, not forming a head, and resembles Cos Lettuce. Its flavor is mild, and is used either as a salad or cooked. Set plants three feet apart and two feet in the row. Ioc. per pkt.; $25 \mathrm{c}$. per oz.; $75 \mathrm{c}$. per $1 / 4 \mathrm{lb}$.; $\$ 2.75$ per $1 \mathrm{~b}$.

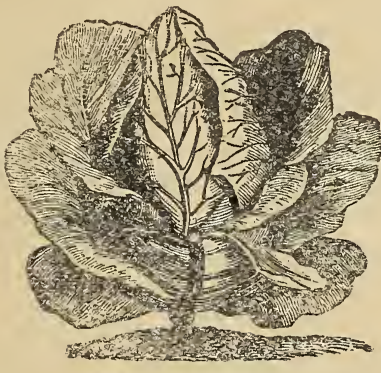

JERSEY WAKEFIELD.

EARLY JERSEY WAKEFIELD.-Extensively grown in all parts of the country as the best and most profitable early variety in cultivation; an extra fine stock. Ioc. per pkt.; 25 c. per oz.; 75 c. per $1 / 4 \mathrm{lb}$.; $\$ 2.75$ per $1 \mathrm{~b}$.

EARLY SPRING.-This variety is of early Summer type, but about one-fifth smaller. It can be planted as close as twenty-one inches apart, owing to its few short outer leaves. Its great value lies in the fact that it is the first early flat cabbage. Ioc. per 1,kt.; $25 \mathrm{c}$. per oz.; 75G per $1 / 4 \mathrm{lb}$.; $\$ 2.75$ per $1 \mathrm{~b}$.

COPENHAGEN EARLY MARKET.-An excellent early variety. Matures at about the time of Charleston Wakefield. Heads very large and round. Leaves light green, head very heavy and it is a very uniform cropper. Ioc. per pkt.; $25 \mathrm{c}$. per oz.; $75 \mathrm{c}$. per $1 / 4 \mathrm{lb}$; $\$ 2.75$ per $1 \mathrm{~b}$.

EARLY CHARLESTON, OR LARGE TYPE OF WAKEFIELD. - The Largest and Best First-Early Cab. bage. This stock was selected from one of the best stocks of Wakefield, a selected from one of the best in its character that we can offer it with confidence to in its character that we can offer it with confidence to
those desiring a Cabbage of this kind. I oc. per pkt.; $25 \mathrm{c}$. per oz.; 75 c. per $1 / 4$ lb.; $\$ 2.75$ per lb.

EARLY SUMMER.-It is about ten days later than the Wakefield, but being of fully double the size it may be classed as the best large early Cabbage. Ioc. per pkt.; $25 \mathrm{c}$. per oz.; 75c. per $1 / 4 \mathrm{lb}$; $\$ 2.75$ per lb.

EARLY FLAT DUTCH.-A valuable early variety; largely grown in the vicinity of New York. Ioc. per pkt.; $25 \mathrm{c}$. per 0z.; $75 \mathrm{c}$. per $1 / 4 \mathrm{lb}$; $\$ 2.75$ per $1 \mathrm{~b}$.

ALL SEASON.-Suitable to plant any time, early or late. A sure leader. Ioc. per pkt.; $25 \mathrm{c}$. per oz.; $75 \mathrm{c}$. per $1 / 4 \mathrm{Ib}$; $\$ 2.75$ per $1 \mathrm{~b}$.

SUCCESSION.-The Succession we regard as the most valuable variety that has been introduced since the Early Summer. It is the best Cabbage for either early or late use ever offered. The Succession is about one week later than the Early Summer, but it is double the size, and is 30 finely bred that in a field of ten acres every head was a magnificent, nerfect specimen, fit for exhibition purposes. roc. per pkt.; 25c. per oz.; $75 \mathrm{c}$. per $1 / 4 \mathrm{lb}$.; $\$ 2.75$ per $1 \mathrm{~b}$.

AUTUMN KING or WORLD BEATER.-A distinct strain of late Cabbage, which is highly spoken of by all market gardeners who have thus far tested it. The heads are of enormous size and very solid. Ioc. per pkt.; 25c. are of enormous size and very solid.
per oz.; $75 \mathrm{c}$. per $1 / 4$ lb.; $\$ 2.75$ ner $1 \mathrm{~b}$.

DANISH BALL HEAD.-A very handsome and extremely hardy imported Cabbage, which is growing in popularity in America, having proven one of our best Winter sorts; it thrives well on thin soils and in highly exposed situations. Heads not quite as large as the $L_{\text {ate }}$ Flat Dutch, but very hard, round, fine grained, and will weigh one-fourth more than other varieties of equal size. Ioc. per pkt.; $25 \mathrm{c}$. per oz.; 75c. per $1 / 4$ lb.; $\$ 2.75$ per $1 \mathrm{~b}$.

SUREHEAD. - A good all-around late Cabbage. roc. per pkt.; 25c. per oz.; $75 \mathrm{c}$. per $1 / 4 \mathrm{lb}$; $\$ 2.75$ per lb.

SELECTED PREMIUM LATE FLAT DUTCH.-TO this we have only to add that the seed offered has been grown from heads uniform in size, large and solid. Those who buy it for the first time will find it to be one of the most satisfactory strains of late Cabbage they have ever used. Ioc. per pkt.; $25 \mathrm{c}$. per oz.; 75c. per 1/4 lb.; $\$ 2.50$ per lb.

ENKHUIZEN GIORY.-Very excellent round headed variety. Matures with Wakefield. Will remain a long time after heading without bursting. Ioc. per pkt.; $25 \mathrm{c}$. per oz.; 75c. per $1 / 4 \mathrm{lb}$; $\$ 2.75$ per lb.

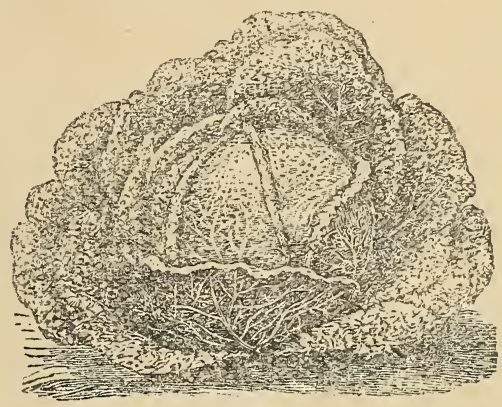

DRUMHEAD SAVOY

DRUMHEAD SAVOY OR PERFECTION.-The larg est heading sort; of excellent flavor. I oc. per pkt.; $25 \mathrm{C}$ per oz.; 75c. per $1 / 4 \mathrm{lb}$.; $\$ 2.75$ per $1 \mathrm{~b}$.

LARGE LATE DRUMHEAD.-Grows to a large size, with round, compact heads. Ioc. per pkt.; $25 \mathrm{c}$. per oz.; $75 \mathrm{c}$. per $1 / 4 \mathrm{lb}$; $\$ 2.75$ per $\mathrm{lb}$.

RED DUTCH.-Used almost exclusively for pickling. Ioc. per pkt.; 25c. per oz.; 75c. per $1 / 4$ 1b.; $\$ 2.75$ per lb.

MAMMOTH ROCK RED.-This is by far the best, largest and surest heading red Cabbage ever introduced. the plant is large, with numerous spreading leaves. The head is large, round, very solid and of deep color inside, as well as outside. Ninety-eight per cent. of the plants will form extra fine heads. The best of the red Cabbages. Ioc. per pkt.; $25 \mathrm{c}$. per oz.; $75 \mathrm{c}$. per $1 / 4 \mathrm{lb}$; $\$ 2.75$ per

\section{CABBAGE PLANTS.}

\section{Price Subject to Fluctuation.}

FOLLOWING EARLY SORTS.

EARLY WAKEFIELD AND EARLY SUMMER.Ioc. per doz.; $75 \mathrm{c}$. per I00; $\$ 5.00$ per 1,000 out of seed bed.

Transplanted plants 20c. pér doz.; \$1.25 per 100.

LATE SORTS.

SUREHEAD, DANISH BALL HEAD, LATE FLAT DUTCH, AUTUMN KING, SUCCESSION.-75c. per I 00; $\$ 4.00$ per I,000.

Special prices given on lots of 5,000 or 10,000 .

\section{CARDOON.}

One ounce will sow roo feet of drill.

Cardoon is grown for the midrib of the leaf, which requires to be blanched in the same manner as celery. Sow early in Spring, where the plants are to remain in drills three feet apart, an inch and a half deep, and thin out the young plants to a foot apart in the drills.

LARGE SPANISH.-1oc. per pkt.; 30c. per oz.; \$1.00 per $\mathrm{x} / 4 \mathrm{lb}$; $\$ 3.00$ per $\mathrm{lb}$. 


\section{CARROT.}

One ounce will sow roo feet of drills; 3 pounds will seed an acre.

The Carrot, like other root crops, delights in a sandy loam, richly tilled. For early crops sow in Spring, as soon as the ground is in good working order; for later crops, they may be sown any time until the middle of June. Sow in rows about fifteen inches apart, thinning out to three or four inches between the plants. For field culture, rows three feet apart, four inches between the rows.

EARLY FRENCH FORCING.-The earliest variety; valuable for forcing; root small and of fine flavor. per pkt.; Ioc. per Oz.; 30c. per I/4 lb.; $\$ 1.00$ per $1 \mathrm{~b}$.

EARLY SCARLET HORN.-An old favorite sort, much esteemed for early Summer use. 5c. per pkt.; I oc. per oz.; 25c. per $1 / 4$ 1b.; 85 c. per $1 b$.

EARLY HALF-LONG RED.-(Stump rooted.) A va. riety intermediate in size and maturity between the pre ceding and Long Orange. 5c. per pkt.; Ioc. per oz.; 25c. per $1 / 4$ lb.; $75 \mathrm{c}$. per $1 \mathrm{~b}$.

CHANTENAY HALF-LONG.-Fine orange scarlet color, very productive; especially desirable for market or home use. The flesh is tender, firm and finely grained. Five inches long, stump rooted. 5c. per pkt.; roc. per oz.; $25 \mathrm{c}$. per $1 / 4 \mathrm{lb}$.; $85 \mathrm{c}$. per $1 \mathrm{~b}$.

OX.HEART OR GUERANDE.Early, short, thick, very smooth and handsome market sort. $5 \mathrm{c}$. per pkt. Ioc. per oz.; 25c. per $1 / 4$ lb.; $85 \mathrm{c}$ per lb.

RUBICON HALF-LONG ORANGE, -It is uniform in shape, and its deep red orange-colored flesh makes it the finest in quality. It is earlier than Danvers. Heavier and thicker at the shoulder. Exceedingly heavy cropper. 5c. per pkt.; 1 oc. per oz.; 25c. per $1 / 4$ lb.; 75 c. per $1 \mathrm{~b}$.

DANVERS.-A variety of great promise, in form midway between the Long Orange and Early Horn class. in color it is of a rich shade of orange, growing very smooth and handsome. It is claimed that this variety will yield the greatest bulk with the smallest length of root of any now grown. 5c. per pkt,; I oc. per oz.; $25 \mathrm{c}$. per $1 / 4 \mathrm{lb}$. 75c. per $1 \mathrm{~b}$.

LONG ORANGE IMPROVED.The roots are of large size. Equally adapted for garden or farm culture. 5c. per pkt.; IOc. per oz.; 25c. per $1 / 4$ lb.; 75 c. per $1 \mathrm{~b}$.

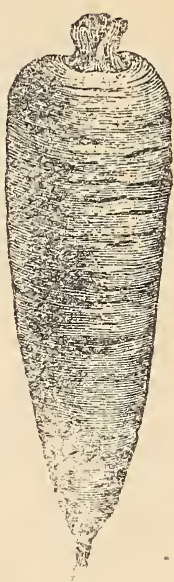

DANVERS.

\section{CATTLE CARROT.}

LARGE WHITE BELGIAN.-A very productive kind grown almost exclusively for stock; grows one-third out of the ground; lower part of the root white, that above the ground green. $5 \mathrm{c}$. per pkt.; roc. per oz.; 25c. per $\mathrm{r} / 4 \mathrm{lb}$.; $65 \mathrm{c}$. per $1 \mathrm{~b}$.

YELLOW BELGIAN.-When young the roots are mild, delicate and of good flavor; when full grown, val. uable for stock. 5c. per pkt.; I oc. per oz.; 25c. per $1 / 4$ lb.; $65 \mathrm{c}$. per $1 \mathrm{~b}$.

\section{CAULIFLOWER.}

One ounce will sow 75 feet of drill and produce 2,500 plants.

Any soil that will grow Cabbage will grow Cauliflower as their requirements are almost similar. But as the product is mors valuable, extra manuring and preparation of the soil will be well repaid.

The seed may be sown in September and wintered over in the same manner as described for early cabbage. Where this is not practicable, it may be had nearly as well by sowing the seeds in the hot-bed in January or February, and transplanting the plants at two or three inches apart, in boxes, or in the soil of another hot-bed, until such time as they are safe to be planted in the open ground, which, in this latitude, is usually from the 15th of March to the Ioth of April. If properly hardened off, they are seldom injured by planting out too early.

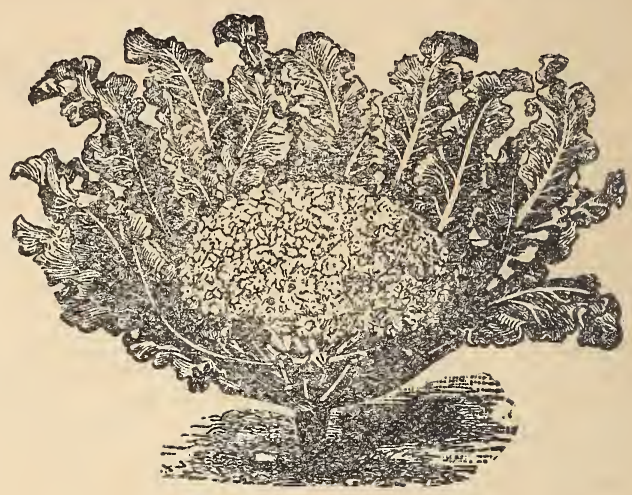

HENDERSON'S EARLY SNOW-BALL.

HENDERSON'S EARLY SNOW-BALI. - It is the earliest of all Caulifiowers. Sown at the same time and under the same conditions with ten other kinds, on the Ist of March, heads of the Early Snow-Ball, measuring nine inches in diameter, are about one week earlier than any other sort. Besides this variety, every plant forms a fine head. In addition to its earliness and greater certainty to head than any other sort, its dwarf habit and short outer leaves allow it to be planted as close as is short outer leaves allow it to be planted as close as 18
inches apart. For forcing, under glass, during Winter and Spring, this variety is particularly well adapted. 25 . per pkt.; \$2.00 per oz.

DRY WEATHER.-Especially adapted to dry soils and long dry seasons. Heads large and pure white. $25 \mathrm{C}$. per pkt.; $\$ 2.00$ per oz.

EXTRA EARLY PARIS.-A well-known, excellent variety. I 5 c. per pkt.; 75c. per oz.

EXTRA EARLY DWARF ERFURT.-A favorite early market variety; large, compact heads of fine quality. 25c. per pkt.; $\$ 2.00$ per oz.

\section{CELERIAC, OR TURNIP-ROOT CELERY.}

One ounce will produce 3,00o plants.

A variety of celery having turnip-shaped roots, which may be cooked and sliced, and used with vinegar, making a most excellent salad. It is more bardy, and may be treated in the same manner as Celery.

GIANT PRAGUE.-Ioc. per pkt.; 20c. pe roz.; 6oc. per $1 / 4$ lb.; $\$ 2.00$ per $1 b$.

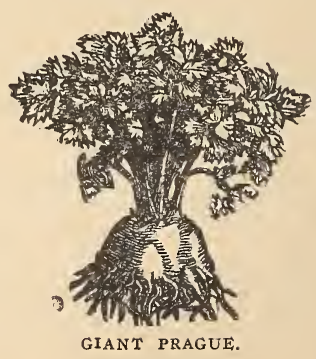

CELERY.

One ounce will sow too-foot row, and produce 3,000 plants.

Sow in open ground as soon as it is fit to work, late in March or ea-ly in $A$ ril. $\mathrm{Keep}$ lear of weeds unti time for transplanting, in June or July. The tops should be shorn off once or twice before transplanting to insure stocky plants. When from four to six inches high, transplant into broad, shallow trenches nearly on the level, three feet apart, and six inches in the rows. The soil should be light, highly manured and moist, or near water, as the plants must be freely watered in dry weather. Earthing up should not be begun until the plants are quite well grown; then earth up gradually, keeping the leaf-stocks close together, so that the earth may not fall into the center of the plant. Never earth up in wet weather or when the dew is on the plant. 
Celery for very late use which is earthed or bunched up early is liable to rust. When severe cold weather comes on, cover with leaves, hay or straw, and place boards on the top to keep out moisture. The covering must be put on gradually, else there will be danger of heating and consequent decay.

EARLY PINK PLUME.-A strong, healthy, compact grower, with no tendency to rust. Stems very solid and crisp, extra early and a iong keeper, remaining, when properly trenched, in perfect condition away into Spring. It posseases a rich, nutty flavor, with stocks of ivory white, suffused with dainty pink, which not only delight the eye, but tempt the palcte of the epicure soc. pes pkt.; 2zc. per oz.; $75 \mathrm{c}$. per $1 / 4 \mathrm{lb}$.; $\$ 2.50$ per $1 \mathrm{~b}$.

GOLDEN YELLOW SELF-BLANCHING.-(French Strain.) This variety of Celery is of a yellowish green color, but as they mature the inner stems and leaves turn a beautiful golden yellow, which adds much to their attractiveness and makes the work of blanching much easier. The handsome color, crispness, tenderness, freedom from stringiness, and fine nutty flavor of this variety make it only necessary to be tried in order to establish it as the standard of excellence as an early sort. roc. per pkt.; 50c. per 0z.; \$1.75 per $1 / 4$ lb.; $\$ 6.00$ per lb.

GIANT PASCAL.-A green sort, very brittle, but crisp and nutty in flavor. 5c. per pkt.; 25c. per oz.; 75c. $1 / 4 \mathrm{lb}$; $\$ 2.00$ per $1 \mathrm{~b}$.

EARL,Y WHITE PLUME.-This Celery is valued because naturally the stalk and portions of its inner leaves and heart are white. By simply tying up the leaves and drawing up the soil with the hoe the work of bleaching is completed. It is ornamental, tender, crisp and of good flavor. roc. per pkt.; 25c. per oz.; 75c. per $1 / 4$ lb.; $\$ 2.50$ per $1 \mathrm{~b}$.

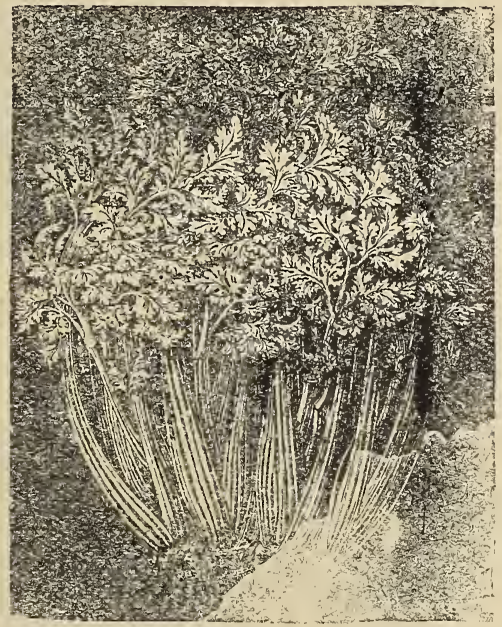

SCKU⿺ACERZ

SCHUMACHER.-Verg popular among New York mariset gardeners. They consider it the beat Winter variety; keeping quality excellent. Grows to large sire, with golden-yellow heart. Very solid and crisp. 5c. per pkt.; 25c. per oz.; 75C. per $1 / 4$ lb.; $\$ 2.50$ per lb.

GOLDEN HEART-Golden Dwarf.-In size and habit of growth it is much the same as the Half-Dwarf kinds, except that, when bleached, the heart, which is large and full, is of waxy, golden yellow, rendering it a most striking and showy variety for either market or private use. It is entirely solid, and of most excellent lavor, and one of the best keepers that has ever been known. 5c. per pkt.; 25c. per oz.; 75c. per $\mathrm{x} / 4 \mathrm{lb}$; $\$ 2.00$ per $1 \mathrm{~b}$.

GOLDEN SELF.BLANCHING.- "American Grown." A most valuable variety which partakes somewhat of the character of the celebrated White Plume, inasmuch as it does not require such high banking-up as the ordinary sort to be fit for the table. It simply needs a slight earthing-up or handling. It is a beautiful waxy, golden, color, very solid, and of a rich nutty flavor. roc. per pkt.; 35c. per oz.; $\$ 1.00$ per $1 / 4$ lb.; $\$ 3.75$ per $1 \mathrm{~b}$.
EASY BLANCHING or EASY BLEACHER.-EX. TRA STRAIN.-A tall-growing white variety of excellent quality, of recent introduction. Bleaches readily with boards. Grows well both on muck and upland. It is not so susceptible to blight as other self-bleaching sorts and quality much better. It is becoming to be the best market variety to plant for profit.. I oc. per pkt.; 50c. per oz.; $\$ 1.50$ per $1 / 41 \mathrm{~b}$.; $\$ 5.50$ per $1 \mathrm{~b}$.

WINTER QUEEN.-Late half dwarf Golden Heart type, of more robust growth. Very good late market sort. IOc. per pkt.; 25c. per oz.; 75c. per $1 / 4 \mathrm{lb}$; $\$ 2.50$ per $1 \mathrm{~b}$.

CELERY SEED. for flavoring, 25c. $1 / 4 \mathrm{lb}$; $75 \mathrm{c}$. per $\mathrm{lb}$.

\section{CELERY PLANTS.}

READY JULY roth.

8,000 to ro,000 plants to the acre.

Varieties same as list of seed above. Price, 50c. per $100 ; \$ 3.50$ per 1,000 ; and 5,000 or over, $\$ 3.00$ per 1,000

\section{CHICORY.}

One ounce will sow 150 feet of drill.

LARGE ROOTED.-Used to mix with, or as a substitute for coffee. Cultivation the same as the carrot. per pkt.; 25c. per oz.; \$75c. per $1 / 4 \mathrm{lb}$.; $\$ 2.50$ per ib.

WITLOOF CHICORY, or FRENCH ENDIVE-Sold on most all fruit and vegetable stands during winter. Drill seed ro inches a part in June; let plants grow until November. Take up and trim to $I 1 / 2$ inches from neck, leaving 8 inches, then plant upright $11 / 2$ inches apart in trenches 16 inches deep. Fill trench with good soil and manure. In four weeks the Endive will be ready for use and is eaten either raw or cooked. Ioc. per pkt.; $25 \mathrm{c}$. per oz.; 85 c. per $1 / 4$ lb.; $\$ 2.50$ per $1 \mathrm{~b}$.

\section{CHERVIL.}

One ounce to 150 feet of drill.

CHERVIL CURLED.-An aromatic sweet herb. The young leaves are used in soups and salads. Sow thinly in May, in drills half an inch deep, one foot apart. roc. per pkt.; I5c. per 0z.; 35c. per $1 / 4$ lb.; $\$ 1.00$ per $1 \mathrm{~b}$.

\section{CHIVES.}

CHIVES (German, Schnitlauch).-A mild flavor of onion kind; very desirable greens for flavoring meats, soups, cottage cheese, etc. Sold in clumps, soc. each; $\$ 1.00$ per dozen.

\section{CORN-Sweet.}

Notice.-These prices are subject to change without notice.

One pound will plant 75 to 100 hills, according to the variety; 12 to 15 pounds will plant an acre; 150 lbs. will sow an acre broadcast for sosling, or half that quantity in dirills; 8 to 12 pounds will plant an acre of yellow field Cors in hill; one-third more in drill.

All varieties of Sweet Corn may be either sown in rows three feet six inches to four feet apart, and the seeds planted at about ten inches in the rows, or planted in hills at distances of three or four feet each way, according to the variety grown or richness of the soil in which is is planted. The taller the variety, or richer the soil, the greater should be the distance apart. We make our first plantings in this vicinity about the middle of hiay, and continue successive planting for $S$ weet Sugar varieties every two or three weeks until the last week in July. In more southerly latitudes planting is begun a month earlier and continued a month later.

HOWLING MOB.-Ears measure from 7 to 9 inches in length. Ripens before Early Crosby's, grains are very white and sweet. Carries generally two ears to stalk and will prove a money-maker in the market. 20c. per 1b.; Io $1 \mathrm{~b}$. lots, I4c. per $1 \mathrm{~b}$.

GOLDEN BANTAM.-Dwarf good garden sort, of creamy yellow; very early; delicious flavor. 20c. per lb.; to $1 \mathrm{~b}$. lots, I5c. per $1 \mathrm{~b}$.

GOLDEN GIANT.-Taller variety than Golden Bantam. Matures early. Ears good length, filled from butt to tip. Kernels regular, heavy yielder, excellent quality. 2oc. per $1 \mathrm{~b}$.; I8c. per $1 \mathrm{~b}$. in Io $1 \mathrm{~b}$. lots. 
EARLY BURLINGTON. - This is the earliest White Corn grewn; ready for use in 60 days. Height of stalks, three to four feet, can be planted earlier than any Sweet Cor11. 20c. per $1 \mathrm{~b}$.; Io $\mathrm{lb}$, lots, I $4 \mathrm{c}$. per $\mathrm{lb}$.

EARLY CHAMPION.-Ripens ahead of Crosby with much larger ears. 20c. per $1 \mathrm{~b}$.; so $1 \mathrm{~b}$. lots, $18 \mathrm{c}$. per $1 \mathrm{~b}$.

EARLY EGYPTIAN.-Second early, very productive, very good inarket gardening variety. 20c. per lb.; $10 \mathrm{lb}$.

EARLY KENDEL'S GIANT.-One of the largest earliest Sweet Corn introduced. An extra market sort oc. Der lb,; Io lb, lots, I4c. per lb.

EARLY PREMO.-A distunci new type of an easly Sweet Corn. It is as early as the Early White Corr. Ears larger and sweet. 20c. per 1b.; Io 1b. lots, I4c. per

EARLY EVERGREEN.-A Second Early, it has all the good qualities of Stowell's Evergrcen. It is about eight days earlier; a little shorter in the ear. Quality of the best. 20c. per lb.; Io $1 \mathrm{~b}$. lots, I $2 \mathrm{c}$. per $\mathrm{lb}$.

HONEY DEW.-Sweet popular Eastern variety. Exceptionally sweet; handsomely formed ears; very productive and medium early. 20c. per lb.; ro $1 \mathrm{~b}$. lots, I4c.

MAMMOTH SUGAR.-A late variety, and one of the larger; productive and fine flavored. 2oc.- per lb.; io lb. ots, I4c. per $1 \mathrm{~b}$. vate garden use. 20c. per $1 \mathrm{~b}$. Io $1 \mathrm{~b}$. lots, I $4 \mathrm{c}$. per $1 \mathrm{~b}$. BLACK SUGAR, MEXICAN.-A variety with black grains; one of the sweetest of all kinds. 20c. per lb.

STOWELL'S EVERGREEN.- "Eastern Stock; sweet est strain known." A late variety, of excellent quality, remaining longer in the green state than any other kind. 20c. per $1 \mathrm{~b}$; ; Io $1 \mathrm{~b}$. lots, I $4 \mathrm{c}$. per $1 \mathrm{~b}$.; Ioc. per lb. in Ioo lb. lots. lots, I 5 c. per lib.

POP CORN, WHITE RICE.-2oc. per 1b.; io 1b. lots, 5 c. per $1 \mathrm{~b}$.

THE COUNTRY GENTLEMEN is, without doubt, the finest of all for private and market use, and greatly resembles the Shoe Peg, except the ars are twice as large, with an average of about nine inches in length, and is very productive, producing from three to four ears to a stalk. Cob is small, giving great depth to the kerneis, which are of a pearly whiteness. Its fine quality makes it most desirable for the market gardener. 20c. per lb. ro $1 \mathrm{~b}$. lots, I4c. per $1 \mathrm{~b}$

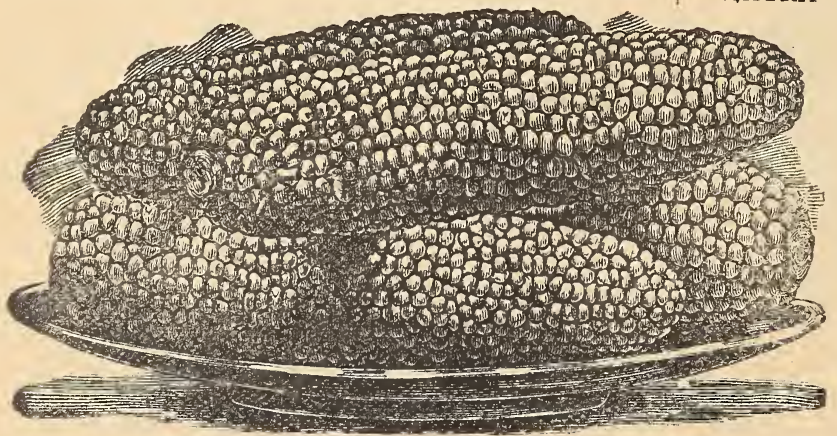

COUNTRY GENTLEMAN.

CORN-Field.

Subject to market fuctuations.

SOUTHERN LARGE WHITE ENSILAGE-For fodder only; a very rapid grower and heavy foliage one of the best silo corns. 8c. per $1 \mathrm{~b}$.; $25 \mathrm{lb}$. lots and over, 6c. per $1 \mathrm{~b}$.

BRISTOL EARLY. - A good, standard, early yellow corn. 8c. per lb.; 25 ib. lots and over, 5c. per lb.

GOLDEN BEAUTY.-The ears are of perfect shape, with from ten to sixteen straight rows of bright golden grains of the largest size, which are filled out to the extreme end of the cob; it is easily shelled, and is in every respect seemingly perfect trpe; it is a visorous grower, attaining eight to ten feet in height, and each stalk produces from two to three ears; matures as early stalk produces from two to three ears; matures as early size, appearance and productiveness. 8c. per lb.; $25 \mathrm{lb}$. ots and over, $6 \mathrm{c}$. per $1 \mathrm{~b}$.
GOLDEN DENT GOURD SEEDThis is a very productive and superior variety; very early; requires less strength of ground, and makes a very fine quality of meal. The grains are very deep, with small cobs. It is a vigorous grower, and very popular in sec tions where the soils are light and sandy. 8c. per $1 \mathrm{~b}$; $25 \mathrm{lb}$. lots and

IMPROVED LEAMING.-The earliest most productive and handsomest Yellow Dent corn in cultivation. $8 \mathrm{c}$ per $1 \mathrm{~b}$; $25 \mathrm{lb}$. lots and over, $6 \mathrm{c}$. per $1 \mathrm{~b}$.

LARGE YELLOW FLINT.-Productive and of good quality. 8c. per lb.; $25 \mathrm{lb}$. lots and over. 6c. per $\mathrm{lb}$.

WOODHULL. - One of the best standard sorts; light grain, large ear, medium size stalk, very productive. $8 \mathrm{c}$. per 1b.; 25 lb. lots and over, $6 \mathrm{c}$.

\section{CORN SALAD, OP FETTICUS.}

One ounce will sow I25 feet of row.

A vegetable used as a salad, and sold to a considerable extent in our markets. It is sown on the first opening of Spring, in rows one foot apart, and is fit for use in six or eight weeks from time of sowing. If wanted to come in early Spring, it is sown in September, covered up with straw or hay as soon
as cold weather sets in, and is wintered over exactly as spinach.

LARGE LEAVED.-Ioc. per pkt.; I5c. per oz.; 50c. per $1 / 4$ lb.; $\$$ I. 50

\section{CRESS, or PEPPER GRASS.}

One ounce will sow 50 feet of row.

A well-known pungent salad. Requires to be sown thickly and covered very lightly at frequent intervals to keep up a succession as it soon runs to seed.

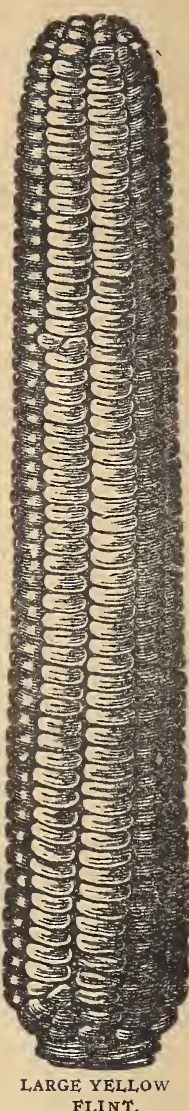

FLINT.

EXTRA CURLED.-Very fine; may be cut two or three times. 5c. per pkt.; I oc. per oz.; $25 \mathrm{C}$ per $1 / 41 \mathrm{~b} . ; 75 \mathrm{c}$. per $1 \mathrm{~b}$.

WATER CRESS.-Ioc. per pkt.; 5๑c. per oz.; $\$ 1.50$ per $1 / 4 \mathrm{lb}$; $\$ 5.00$ per lb.

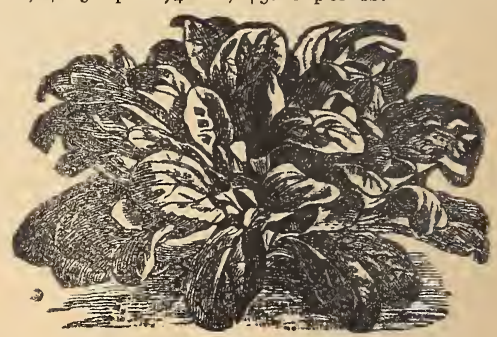

LARGE LEAVED

\section{CUCUMBER.}

One ounce will plant 50 hills, two pounds will plant an acre.

Cucumbers succeed best in warm, moist, rich, loamy ground. They should not be planted in the open air until there is a prospect of settled warm weather. Plant in hills about four feet apart each way. The hills should be previously prepared by mixing thoroughly with the soil of each a shovelful of well-rotted manure. When all danger from insects is past, thin out the plants, leaving three or four of the strongest to each hill. The fruit should be plucked when large enough, whether required for use or not, as if left to ripen on the vines, it destroys its pro. ductiveness.

EARLY FORTUNE.-Early, dark color, and prolific. Fruit averages about 10 inches in length. $5 \mathrm{c}$. per pkt. I 5c. per oz.; 40c. per $1 / 4$ lb.; $\$ 1.25$ per $1 \mathrm{~b}$. 
EARLY IMPROVED WHITE SPINE.-A favorite market va-. riety of medium size, deep green, flesh crisp and of fine flavor. 5c. per pkt.; 15c. per oz.; 35c. per $1 / 4$ lb.; \$1.00 per lb.

E A R L Y IMPROVED AR. LINGTON WHITE SPINE.-It is a week earlier than the Early lific. It retains a beautiful green color longer than any other sort; size, medium; an elegant slicing sort. 5c. per pkt.; I5C. per oz.; $35 \mathrm{c}$. per $1 / 4 \mathrm{lb}$; ; $\$$.00 per $1 \mathrm{~b}$.

FORDHOOK FAMOUS.-It is said to be the finest flavor of all, most beautiful and best long Green Cucumber upon the market. Vines produce an enormous crop, being of unusually vigorous growth, with large, thick, heavy leaves, which withstand the attacks of insects. Fruit perfectly smooth and very dark green and handsome. Fruits measure 12 to 18 inches long. They are always straight, never turn yellow, and are very solid. 5c. per pkt.; 15c. per 0z.; 400 . per $1 / 4$ lb.; $\$ 1.25$ per lb.

COOL AND CRISP "New".A very good variety for general house use. $5 \mathrm{c}$. per pkt.; $15 \mathrm{c}$. per oz.; 35c. per 1/4 lb.; \$I.00 per $1 \mathrm{~b}$.

GREEN PROLIFIC.-A good pickling sort. $5 \mathrm{C}$. per pkt.; $15 \mathrm{C}$. per oz.; 35c. per $1 / 4$ lb.; $\$ 1.00$ per IMPROVED ARLINGTON Ib.

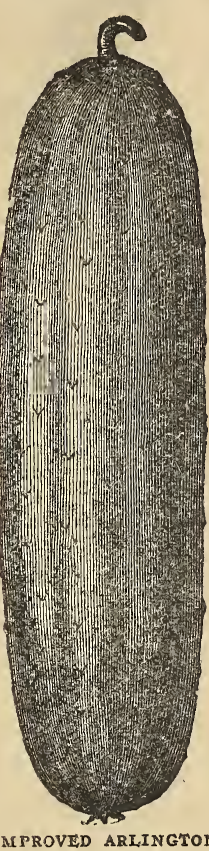

WHITE SPINE.
NEW DAVIS PERFECT.-Resembles a hot-house cucumber. Long, straight, dark green in color; almost seedless. Equally good for outdoors and hot-house grow. ing. 5c. per pkt.; I5C. per 0z.; 40c. per $1 / 4$ lb.; \$I.25 per $1 \mathrm{~b}$.

EARLY CLUSTER.-A much-esteemed early sort; growing in clusters, and extremely productive. 5c. per pkt.; I 5c. per oz.; 40c. per $1 / 4 \mathrm{lb} ; \$ \mathrm{r} .25$ per $\mathrm{lb}$.

BOSTON PICKLING.-It is largely used about Boston by market gardeners. A very productive kind, of superior quality. 5c. per pkt.; $15 \mathrm{c}$. per oz.; 35c. per $1 / 1 / 4$ lb.; $\$ 1.00$ per $1 \mathrm{~b}$.

LONG GREEN, OR JERSEY PICKLE.-A fine, long fruit, of excellent quality, dark green, firm and crisp; very productive. 5c. per pkt.; I5c. per oz.; $40 \mathrm{c}$. per $1 / 4$ lb.; $\$$ I.25 per $1 \mathrm{~b}$.

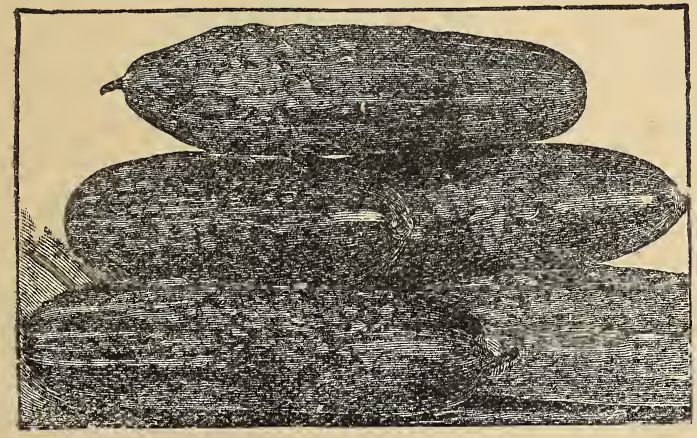

DAVIS PERFECT.

LONG GREEN TURKEY.-Late, dark green, excellent fruit, large and productive. 5c. per pkt.; 15c. per oz.; 40c. per $1 / 4$ lb.; $\$ 1.50$ per lb.

WEST INDIA GHERKIN, or BUR.-Used only for pickles. 5c. per pkt.; 20c. per oz.; 50c. per $1 / 4$ lb.; $\$ 1.75$ per $1 \mathrm{~b}$.

\section{DANDELION.}

One ource, will sow 150 -foot row.

IMPROVED THICK LEAVED.-A very early and healthful Spring salad. Sow early in the Spring in drills, eighteen inches apart, and thin out to six inches in the drills. roc. per nkt.; $75 \mathrm{c}$. per oz.; $\$ 2.50$ per $1 / 4 \mathrm{lb}$.; $\$ 9.00$ per $1 \mathrm{~b}$.

\section{DILL HERB.}

Used extensively for culinary use and for putting with cucumbers when pickling, producing the famous Dill

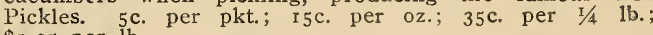
$\$ 1.25$ per $1 \mathrm{~b}$.

\section{EGG PLANT.}

One ounce will produce about 1,000 plants.

The Egg Plant will thrive well in any good garden soil, but will repay good treatment. The seed should be sown in hot-beds the second week in March, care being taken to protect the young plants frorn cold at night. Plant out about June ist, about two and a hall feet apart. If no hot-bed is at hand, sufficient plants may be raised for a small garden by sowing a few seeds in common flower pots or boxes in the house.

IMPROVED NEW YORK SPINELESS.-In every respect superior to the New York Improved. The habit of the plant is low and branching, and is quite free from spines both on the plant and calyx of the fruit, which sre of the largest size and most perfect form. It is earliex than either of the old varieties, therefore most valuable to the grower of this delicious vegetable. roc. per pkt.; $40 \mathrm{c}$. per oz.; \$I.35 per $1 / 4 \mathrm{lb}$; $\$ 5.00$ per $1 \mathrm{~b}$.

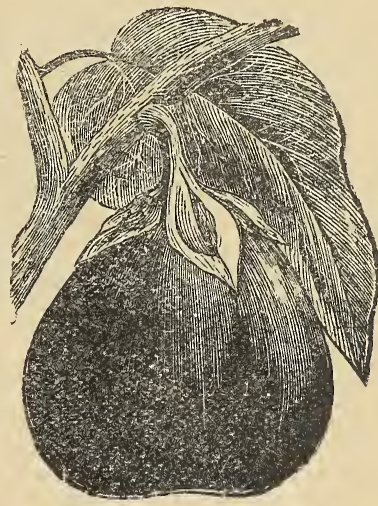

BLACK BEAUTY.

EARLY BLACK BEAUTY.-Earlier than any other sort. Fruit jet black, holding its black color during its maturing season. Very productive, with uniform size fruit. Ioc. per pkt.; 40c. per oz.; \$1.35 per $2 / 4$ lb.; $\$ 5.00$ per lb.

THORNLESS, LARGE ROUND PURPLE.-Used both for private and market garden. An imposing variety; productive, vigorous, good in quality, often reaching a weight of twelve pounds. roc per pkt.; $40 \mathrm{c}$. per oz.; $\$ 1.35$ per $1 / 4$ lb.; $\$ 5.00$ per $1 b$.

\section{EGG PLANTS (Pot Grown)}

\section{(Ready May 1st.)}

IMPROVED NEW YORK SPINELESS.-In pots, each; $\$ 1.00$ per doz.; $\$ 7.00$ per roo. Out of seed beds, $35 \mathrm{c}$. per doz.; $\$ 1.75$ per 100.

Boxed plants roc. each; $\$ 1.00$ per doz.

Special prices on application, in qua.tities.

\section{ENDIVE.}

One, ounce will sow a roo-foot row.

Endive is one of the best salads for Fall and Winter 1se. Sow for an early supply about the middle of April. As it is used mostly in the Fall months, the main sowings are made in June and July, from which plantations are formed one foot apart in each way, in August and Septem ber. It requires no special soil or manure, and after planting is kept clear of weeds until the plant has obtained its full size when the process of blanching begins. This is effected by gathering up the leaves and tying them by their tips in a conical form, with bass matting. This ex. their tips in a conical form, with bass mateing. This in cludes the light and air from the inner leaves, which in the course of from three to six weeks, according to the temperature at the time, become blanched. Another and simpler method consists in covering up the plants as they pose-by excluding the light-as the tying up. 
GREEN CURLED.-Very hardy; leaves dark green; tender and crisp. 5c. per pkt.; Ioc. per oz.; 35c. per $1 / 4$ lb.; \$1.00 per lb.

FRENCH MOSS CURLED.-From the density of its foliage, this variety is heavier than the Green Curled equally agreeable as a salad, and either green or blanched is particularly handsome. 5c. per pkt.; Ioc. per oz.; $35 \mathrm{c}$. er $1 / 4 \mathrm{lb}$; $\$ 1$.00 per $\mathrm{lb}$

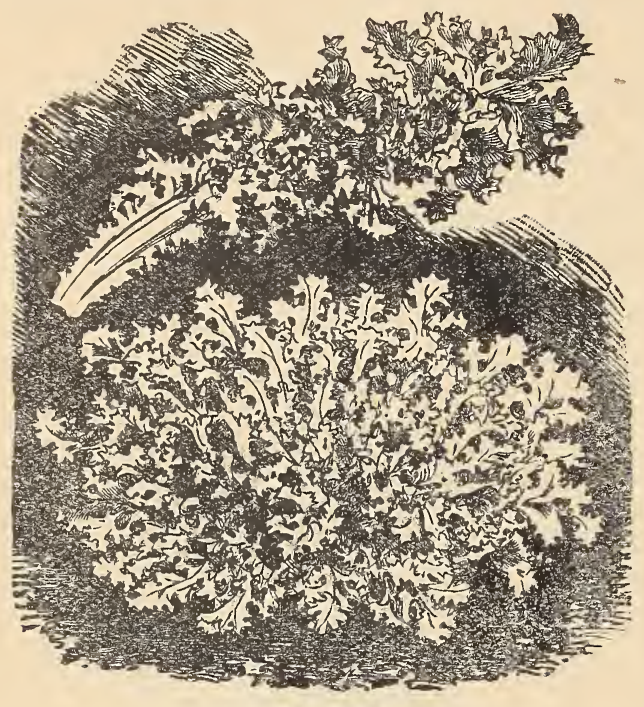

MOSS CURLED.

BATAVIAN BROAD LEAVED, or ESCAROLIELeaves broad, light green, nearly plain, used in stews and soups. 5c. per pkt.; Ioc. per oz.; 35c. per $1 / 4$ lb.; \$I.00 per $1 \mathrm{~b}$.

WHITE CURLED.-Leaves pale green; growe to large size; always crisp and very tender. 5c. per plt.; 15c. per 0z.; 5.oc. per $1 / 41 \mathrm{~b}$.; $\$ 1.75$ per lb.

ESCAROLLE.-Broad, thick ribs, with slightly wrinkled leaves. 5c. per pkt.; Ioc. per oz.; $35 \mathrm{c}$. per $1 / 4 \mathrm{lb}$. $\$ 1.00$ per $1 b$.

\section{FENNEL HERB.}

Annual, height, 2 feet; fine feathery foliage. 5c. per pkt.; I 5c. per oz.; 40c. per $1 / 4$ lb.; $\$$ I.5O per lb.

\section{GARLIC.}

Used for flavoring soups, stews and other dishes. Garlic thrives best in a light, well-enriched soil. The sets should be planted in early Spring, in rows one foot apart, and from one to five inches between the plants in the rows. The crop matures in August, when it is harvested like the onion.

GARLIC SETS. -25 c. per lb.

\section{HERBS.}

\section{SWEET POT AND MEDICINAL HERBS.}

No garden is complete without a few Herbs for culinary and medicinal purposes, and care should be taken to harvest them properly. This should be done on a dry day, just before they come in full bloom, then dried quickly and packed closely, entirely excluded from the air. Sow in the Spring, in shallow drills, one foot apart, and when well up thin out or transplant to a proper distance apart.

ANISE (Pimpinella Anisum).-Biennial. Ioc. per pkt.; I5c. per oz.; $\$ 1.25$ per $1 \mathrm{~b}$.

BASIL SWEET (Ocymum Basilicum).-Annual, $6 \mathrm{ft}$. IOc. per pkt.; 25c. per oz.; \$2.50 per lb.

BORAGE (Borago Officinolis).-Excellent for bees. Annual, 3 ft. roc. per pltt; 25c. per oz.; \$1.75 per lb.

CARAWAY (Carum Carai).-Perennial, $2 \mathrm{ft}$. Ioc. per kt.; 15c. Fer oz.; $\$ 1.00$ per lb.

CASTOR OIL PLANT (Ricinis Communis).-Annual, $6 \mathrm{ft}$. Ioc. per pkt.; 20c. per oz.; \$I.50 per lb.

CORIANDER (Coriandum Sativum).-Annual, $2 \mathrm{ft}$ c. per pkt.; 15c. per oz.; $\$ 1.00$ per lb.
DILL, (Anethum Graveolens).-Biennial, $3 \mathrm{ft}$. $5 \mathrm{c}$. pes pkt.; I5c. per oz.; $\$ 1.25$ per $1 \mathrm{~b}$.

FENNEL (Anethum Foeniculum)-Perennial, $6 \mathrm{ft}$. 5c. per pkt.; 15c. per oz.; $\$ 1.50$ per lb.

HOPS SEED (Humulus Impulus).-1oc. per plkt.; $35 \mathrm{c}$. per oz.; $\$ 1.25$ per $1 / 4 \mathrm{lb}$; $\$ 4.00$ per $1 \mathrm{~b}$.

HOREHOUND (Marubium Vulgare).-Perennial, a t. Ioc. per pkt.; $25 \mathrm{c}$. per oz.; $\$ 3.00$ per $1 \mathrm{~b}$.

LAVENDER (Lavendula Spica).-Perennial, a ft Ioc. per pkt.; $25 \mathrm{c}$. per oz.; $\$ 3.00$ per $1 \mathrm{~b}$.

MARJORAM, SIVEET (Origanum Marjorana).Annual, I ft. Ioc. per pkt.; 25c. per oz.; $\$ 3.00$ er lb. ROSEMARY (Rosemarinus Officinalis).-An aromatic herb. Ioc. per plkt.

RUE (Ruta Graveolens).-Perennial, 3 ft. ioc. pe: pkt.; $25 \mathrm{c}$. per oz.

SAFFRON.-ICc. per pkt.; 25c, per oz.

SAGE (Salvia Officinalis).-Annual, I ft. soc. per pkt. oc. per oz.; $\$ 4.50$ per $1 b$.

SUMMER SAVORY (Satureia Hortensia).-Annual, ft. Ioc. per pkt.; 3oc. per oz.; $\$ 3.00$ per $1 \mathrm{~b}$.

THYME BROAD-LEAVED (Thymus Vulgaris)Perennial, i ft. Ioc. per pkt.; 5oc. per oz.; $\$ 6.00$ per $1 \mathrm{~b}$

WORMWOOD (Artemesia Absinthium).-Perennial. Ioc. per pkt.; 3oc. per oz.; $\$ 3.00$ per lb.

\section{KALE, OP BORECOLE.}

One ounce will produce about 2,500 plants.

Kale or borecole may be grown in almost any soil, but the richer it is the more abundant the product. Sow from the middle of April to the beginning of $\mathrm{May}$, in prepared beds, covering the seeds thirly and evenly; transplant in June, and treat in the same manner as for cabbage. Of all the cabbage tribe, this is the most tender and delicate, and would be much more extensively grown than it is if its excellent qualities were generally known. The varie ties are all extremely hardy, and are best when touched by frost.

GREEN CURLED SCOTCH.-A rather dwarf variety, growing about eighteen inches in height, but spreading under good cultivation to three in diameter Leaves of bright green, beautifully curved. Ioc. per pkt.; 15c. per oz.; 5oc. per $1 / 4$ lb.; $\$$ I.50 per lb.

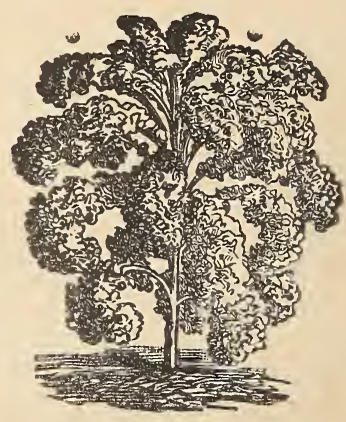

GREEN CURLED SCOTCH.

DWARF GERMAN GREEN.-Ioc. per pkt.; r $5 \mathrm{c}$. per oz.; 35c. per $1 / 4$ lb.; $\$ 1.00$ per $1 b$.

SIBERIAN CURLED.-This variety grows a little larger and coarser than the preceding. The leaves are not so deeply curled, and are of a bluish-green color. Very hardy. Ioc. per pkt.; I I c. per oz.; 50c. per $1 / 4$ lb.; $\$ \mathrm{I} .50$ per $1 \mathrm{~b}$

\section{KOHL-RABI.}

One ounce will produce about 2,500 plants.

A vegetable intermediate between the Cabbage and the Turnip. It is best cultivated by sowing the seed in row 2 in May, June and July, according to the latitude. In this distrint we sow through June for succession, in rows eighteen inches apart, thinning out to eight inches between the plants. It is rather difficult to transplant, and it is generally preferable to sow the whole crop from the secd and thin out where it stands, although when the weather is favoraßle the thinnings may be planted at the distance above named. 


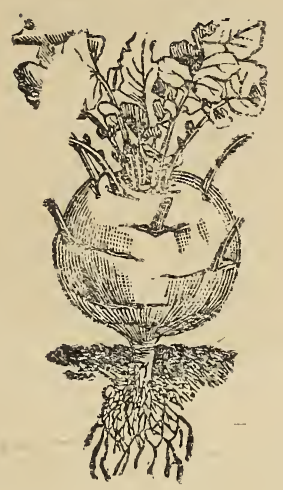

WHITE VIENNA.

EARLY WHITE VIENNA.-Flesh white and tender. The best market sort. Excellent for table use. Ioc. per pkt.; 20c. per oz.; 60c. per $1 / 4$ lb.; $\$ 2.00$ per lb.

EARLY PURPLE VIENNA.-Different from the above in color, which is of a bluish-purple. roc. per pkt.; $20 \mathrm{c}$. per oz.; 60c. per $1 / 4$ lb.; $\$ 2.00$ per lb.

\section{LEEK.}

One ounce will sow a drill of about roo feet.

The Leek is very hardy and easily cultivated. It succeeds best in light, but well enriched soil. Sow as early in Spring as practicable, in drills one inch deep and one foot apart. When six or eight inches high, they may be foot apart. transplanted in rows ten inches apart each way, as deep as possible, that the neck, being covered, may be blanched.
If fine Leeks are desired, the ground can hardly be made too rich.

LARGE AMERICAN FLAG.-A favorite market variety 10c. per pkt.; 20c. per oz.; $65 \mathrm{c}$. per $1 / 4 \mathrm{lb}$.; $\$ 2.00$ per lb.

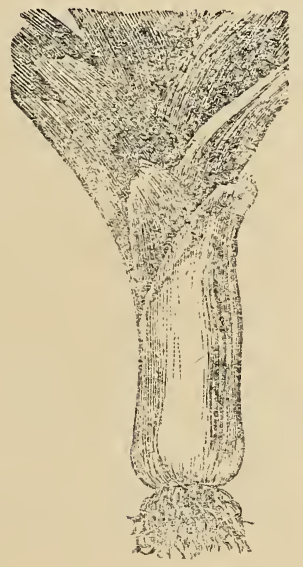

AMERICAN FLAG.

\section{LETTUCE.}

One ounce will sow about 10o-foot row.

The cultivation of Iettuce is universal by all who have gardens, and from its tractable nature and freedom from nearly all insects and disease, it is manageable in the hands of everyone. For main early crop, seed may be sown in the open ground, middle of September, and transplanted to cold-frames as soon as large enough to handle, being wintered over in the same manner as early Cabbage. In dry, well sheltered spots, by covering up with leaves or litter, late in the season. Lettuce plants may be saved over Winter without glass covering, in maythern parts of the country, without difficulty. The olants for setting out in the Spring are also $80 \mathrm{wn}$ in cold-frames in February and in hot-beds in March, and by carefully covering up at night, makes plants to set out in April; but these are never so good as those wintered over. For successive crops, sowings may be made in the open ground as early as Spring opens, until July.

WAYAHEAD.-Quality very fine, heads firm, excellent for both cold frames and open ground. It is the surest header of all lettu'e. Outer leaves are light green, center blanches nicely. 3t will stand longer than any other let. tuce before going to seed. 5c. per pkt.; 20c. per oz.; 40c. per $1 / 4$ lb.; $\$$ I 25 per lb.

MAY KING.-An early hardy lettuce. One of the best varieties to plant in Fall for under-glass or early Spring forcing. Heads large and solid; of light green color; close outer leaves; one of the best market sorts. 5c. per pkt.; I5c. per oz.; 35c. per $1 / 4$ lb.; $\$ 1.00$ per th.

EARIYY FORCING.-So named because of its adaptability for forcing under glass, forming crisp, hard head before any other known sort has commenced to head. 5c. per pkt.; 15c. per oz.; 40c. per $1 / 4 \mathrm{lb}$.; \$1.25 per lb.

BIG BOSTON. - This variety is identical in color, shape and general appearance with the famous Boston Market Lettuce, but it is double the size. It is about a weet later in maturing, but its solidity and greater size of head will make it a most desirable sort. A most desirable variety either for forcing or open-ground planting. $5 \mathrm{c}$. per pkt.; I 5c. per oz.; $35 \mathrm{c}$. per $1 / 41 \mathrm{~b}$; $\$ 1.00$ per $1 \mathrm{~b}$.

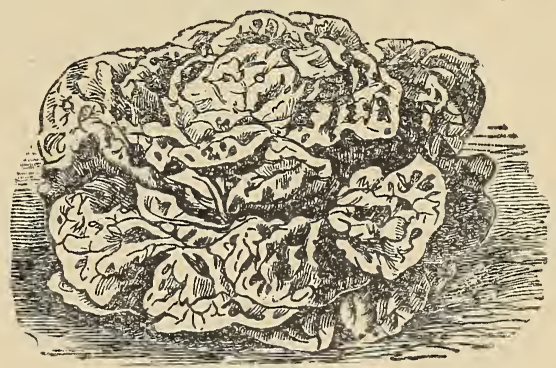

BIG BOSTON.

EARLY CURLED SILESIA.-This variety, properly speaking, does not head, but forms a compact, close mass of leaves. The earliest and leading market sort. 5c. per pkt.; 10c. per 0z.; 35c. per $1 / 4 \mathrm{lb}$; $\$ 1.00$ per lb.

SIMPSON, BLACK SEEDED CURLED. - Large, loose, curly head, light color, good early sort. 5c. per pkt.; r 5 c. per oz.; 40c. per $1 / 4$ lb.; $\$ 1.25$ per $1 \mathrm{~b}$.

BOSTON MARKET. - (True.) A superb variety. Grows very compact, and is beautifully white and crisp. 5c. per pkt.; 15c. per 0z.; 40c. per $1 / 4 \mathrm{lb}$.; $\$ 1.25$ per lb.

GRAND RAPIDS CURLED.-A famous shipping Lestuce, loose, curley-headed, forcing sort. $5 \mathrm{C}$. per pkt.; $15 \mathrm{C}$. per oz.; 40c. per $1 / 4$ lb.; $\$ \mathrm{I} .25$ per $1 \mathrm{~b}$.

LARGE NEW YORK OR LOS ANGELES WONDER FUL. - It is of unusual size and solidity of head, mostly as solid as an early Summer Cabbage, which in general form it somewhat resembles. The variety blanches itself naturally, is crisp, tender and of excellent flavor, and always free from bitterness. It is not a forcing variety, but is one of the best for Summer use ever introduced. 5c. per pkt.; 20c. per oz.; 6oc. per $1 / 4 \mathrm{lb}$; $\$ 2.00$ per $1 \mathrm{~b}$

LARGEST OF ALL.-A very showy sort, being a very large green cabbaging variety; heads well formed an monstrous in size. Altogether desirable, both for family use and market garden. Truckers can adopt it with con. fidence, as it is sure to sell on its own merits. $5 \mathrm{c}$. per pkt.; 20c. per oz.; 60c. per $1 / 41 \mathrm{~b}$.; $\$ 2.00$ per lb.

PHILADELPHIA DUTCH BUTTER HEAD.-A verY reliable heading variety. Slow to shoot to seed, and of superior quality, highly recommended. The leaves are dotted with dusty freckles, 5c. per pkt.; 15c. per oz.; 40c. per $1 / 4$ lb.; $\$ 1.25$ per $1 b$.

ROMAINE OR PARIS WHITE COS.-Forms long, upright heads of narrow leaves, which are crisp and re freshing; withstands the summer heat. 5c. per pkt.; I5c. per oz.; 40c. per $1 / 41 \mathrm{lb}$; $\$ \mathrm{I} .25$ per $\mathrm{lb}$.

ICEBERG.-A large, hard-heading, curled variety, very crisp. 5c. per pkt.; 20c. per oz.; 6oc. per $1 / 41 \mathrm{~b}$.; $\$ 1.5$ per $1 \mathrm{~b}$. 
SALAMANDER. - The Salamander is the best variety for Summer use, forming good-sized, compact heads. Color, light green outside, and white on the inside. Its great merit, however, is that it will withstand drought and heat, and remain longer in head than any other ver $1 \mathrm{~b}$.

BLACK SEEDED BUTTER.-Similar to Tennis Ball, but larger in all its parts. Used exclusively as an -ut-door variety. 5c. per pkt.; I5c. per oz.; 40c. per $1 / 4$

\section{MANGEL-WURZEL or CATTLE BEETS.}

\section{MARTYNIA.}

One ounce will sow about a 150 -foot row.

The seed pods are used, to a consi erable extent, for pickling, when gathered green and to ider. Sow in the opes ground, in May, transplant about two feet apart

MARTYNA PROBOSCIDEA.-5c. per pkt.; 2oc. per oz.; 75 c. per $1 / 4$ lb.; $\$ 2.50$ per $1 \mathrm{~b}$.

\section{MELON-MUSK.}

One ounce will plont about 75 hills; two pounds wibl plant an acre.

Melons thrive best in moderately enriched light ooil The tills should be six feet apart each way. Previous to planting, incorporate well with the woil in each hill couple of shovelfuls of thoroughly rotted manure. Plant tweive to fifteen seeds in each hill early in May, and when well up, thin out to three or four of the most prom ising. Pinch off the leading shoots as the growth be comes too luxuriant, and if the truit sets out numerously, thin out when young, which will increase the size of those remaining, and cause them to ripen quicker.

FORDHOOK.- Orange flesh roughly netted, the flesh very thick, resembles Jenny $L_{\text {ind }}$ in shape. Vine strong, vigorous grower, branching, frequently setting five to nine melons close to hill. I5c. per oz.; 40c. per $1 / 4$ lb.; \$1.25 per $\mathrm{lb}$.
EXTRA EARLY HACKENSACK-A week to ten days earlier than the old Hackensack. Small foliage. Profitable for market. Most in demand in New York and Eastern markets. I 5c. per oz.; 4oc. per $1 / 4$ 1b.; \$I.25 per $1 \mathrm{~b}$.

HACKENSACK OR TURK'S CAP.-The most popular variety of Musk Melon grown by New York market gard eners. It attains a large size, is round in shape, flattened at the ends, is of a most delicious flavor, and wonderfully productive. 15c. per oz.; 40c. per $1 / 4$ lb.; $\$ \mathrm{r} .25$ per $1 \mathrm{~b}$.

CITRON.-(Preserve.) A round handsome fruit, of small size, used in making sweet-meats, and preserves. 15c. per oz.; 40c. per $1 / 4$ lb.; $\$ 1.25$ per $1 \mathrm{~b}$.

MILLER'S CREAM.-The flesh is of a rich salmon color, very thick, sweet and melting in quality. The rind is very thin and finely netted, resembling in shape the Pineapple. r $5 \mathrm{c}$. per oz.; 40c. per $1 / 4$ 1b.; \$1.50 per $1 \mathrm{~b}$.

MELON-Water.

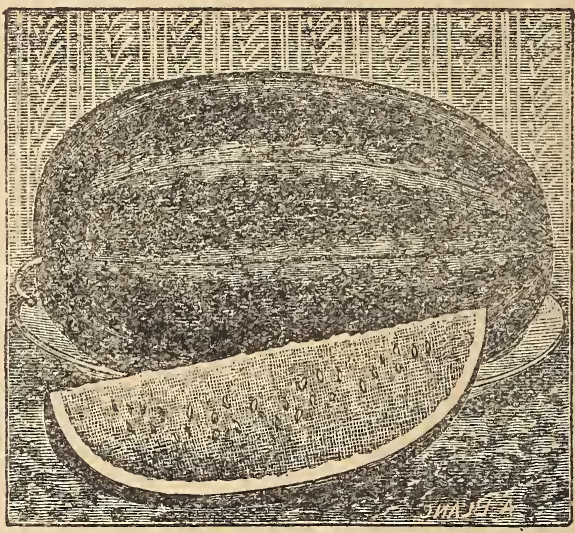

TOM WATSON.

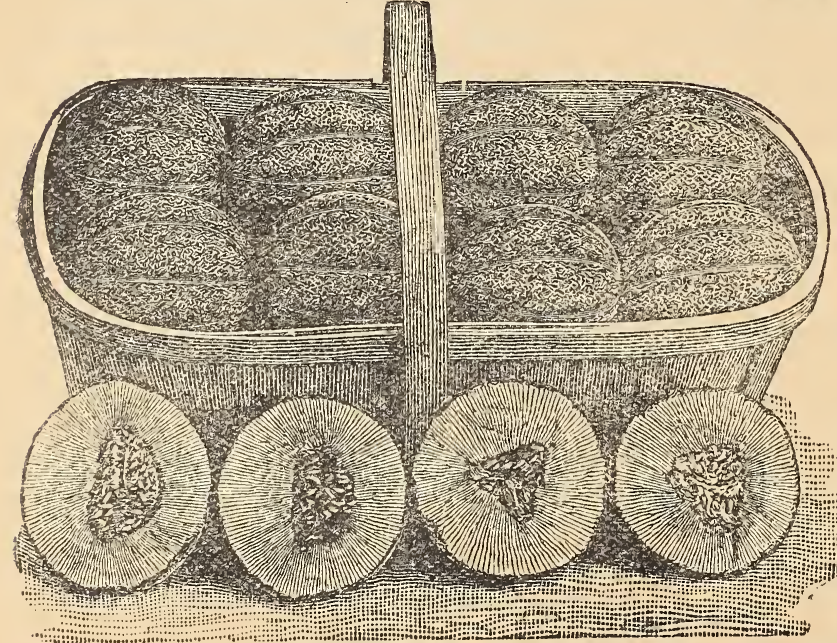

ROCKY FORD.

ROCKY FORD.-(The Great Colorado Nutmeg Melon.) Nutmeg shape, small to medium in size, pale green, finely netted, flesh green, quality very fine. I5C per oz; $40 \mathrm{c}$ per $1 / 4 \mathrm{lb}$; $\$ 1.25$ per $1 \mathrm{~b}$.

PAUL ROSE, or OSAGE.-This salmon-fleshed Musk Melon surpasses anything yet introduced. The color is of a beautiful netted gray underlaid by dark green rind; the flavor is delicious; flesh, salmon, very thick and extra. ordinarily sweet; size of the Netted Gem. I5c. per oz.; 40c. $1 / 4 \mathrm{lb}$; $\$ \mathrm{r} .25$ per $\mathrm{lb}$.

JENNY LIND.-True. The earliest of the Musk Melons, of small size, but the sweetest in flavor. I5c. per oz.; 40c. per $1 / 4$ lb.; $\$ 1.25$ per $1 b$.

GOLDEN JENNY.-Small, but highly prized by the most experienced growers of Melons. I5c. per oz.; 40c. per $1 / 4$ lb.; $\$ 1.25$ per $1 \mathrm{~b}$.
One pound will plant from 50 to 75 hills:

Cultivate exactly as for Musk Melon, except that the hills should be just double the distance apart, namely, eight and ten feet.

KLECKLEY SWEET.-Most popular Melon for home market. Medium size, oblong. dark green color; flesh bright scarlet; solid heart; crisp, sugary, and entirely free from stringiness. 5c. per pkt.; roc. per oz.; $30 \mathrm{C}$ per $1 / 4$ lb.; $75 \mathrm{c}$. per $1 \mathrm{~b}$.

TOM WATSON.-Large oblong melon, dark green skin, with thick netting; rind thin, tough: flesh bright red, very sweet. roc. per oz.; 3oc. per $1 / 4$ lb.; $75 \mathrm{c}$. per $1 \mathrm{~b}$.

DIXIE.-Large, dark rind Melon, oblong; quality good; an excellent market sort. IOC per oz.; 30c. per $1 / 4 \mathrm{lb}$; $75 \mathrm{c}$. per $1 \mathrm{~b}$.

LONG LIGHT ICING OR GRAY MON ARCH.-A very large, long, light rind $\mathrm{Mel}$ on; flesh crimson. roc. per oz.; 30c. per $1 / 4 \mathrm{lb}$; $75 \mathrm{c}$. per $1 \mathrm{~b}$

CUBAN OUEEN.-A Melon of mammoth size, reaching over $60 \mathrm{lbs}$. in weight. The quality is equal to the best of any of the sorts. roc. per oz.; $25 \mathrm{c}$. per $1 / 4 \mathrm{lb}$; $75 \mathrm{c}$. per $1 \mathrm{~b}$.

MOUNTAIN SWEET.-Fruit oblong dark green; rind thin; flesh red, solid and very sweet. roc. per oz.; 30c. per $1 / 4 \mathrm{lb}$; $75 \mathrm{c}$. per $1 \mathrm{~b}$.

ICING, DARK GREEN RIND.-Shape, size and flavor same as Light Icing, but dark skin. roc. per oz; 30c. per $1 / 4$ lb.; $75 \mathrm{c}$. per $1 \mathrm{~b}$.

COLE'S EARLY.-Very hardy; sure cropper. Flesh dark red, delicate and extremely sweet; medium size, nearly round; rind green, striped with lighter shades. 10c. per oz:; 3oc. per $1 / 4$ lb.; $75 \mathrm{c}$. per $1 \mathrm{~b}$.

ICING, LIGHT GREEN RIND.-One of the best of III Melons. Always of good flavor; rind very thin; un excelled in all good qualities. Round in shape. roc. per 0z.; 35c. per $1 / 4$ lb.; $\$ 1.00$ per $1 \mathrm{~b}$.

KOLB'S GEM-A new, chunky, dark-seeded Melon. Quality good. Very showy and an excellent shipper. Ioc. per oz.; 35c. per $1 / 4$ lb.; 75 c. per $1 \mathrm{~b}$. 
SWEET HEART.-One of the best market Melons. Flesh bright red, solid and very tender, melting and sweet. The Melons retain their good quality for a long time after ripening. Ioc. per oz.; 30c. per $1 / 4 \mathrm{lb}$; $75 \mathrm{c}$. per $\mathrm{lb}$.

ICE CREAM.-White seeded true. Fruit of medium size, nearly round, skin pale green, rind very thin; flesh scarlet, solid, crisp and delicious. roc. per oz.; 30c. per $1 / 4 \mathrm{lb}$; $\$ 1.00$ per $1 \mathrm{~b}$.

\section{MUSHROOM SPAWN.}

Ten pounds will spawn ten feet square.

Mushrooms may be cultivated much easier than is gen erally supposed. They can be grown in a cellar or shed or in beds prepared in the open air same as hot-beds. Take fresh horse manure, shake it well apart and lay it in heap to ferment, turn and mix it well every three or four days by shaking the outside of the heap, which is cold, and the inside, which is hot, together, so that every part of it may be equally fermented and deprived of its noxious qualities. When the dung is in a fit state to be made into a bed, which will be from two to three weeks after it has been put together to ferment, select a dry spot for a foundation, mark out the bed, which should be four feet wide and as long as you may choose to make it. In forming the bed mix the dung well together, beating it down with a fork until from 18 to 24 inches thick. In this State it may remain until the temperature is suffi. ciently moderate for spawning, which may be ascertained by trial sticks thrust in different parts of the bed.

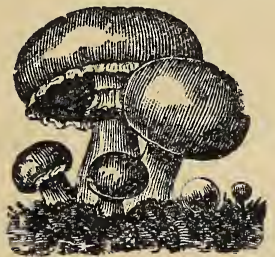

ENGLISH SPAWN.

Divide the large cakes of Spawn into small lumps, plant them two inches below the surface and six inches apart, covering with two inches of fine, light soil, and press down evenly. When finished, cover the bed three inches thick with clean straw and protect from heavy rains. The mushrooms will make their appearance in from four to six weeks, according to the season.

Special pamphlet furnished on application.

AMERICAN SPAWN.-Pure culture. 35t per lb.

Brick form.

\section{MUSTARD.}

One ounce will sow a roo-foot row.

A pungent salad, used sometimes with cress. Sow thickly in rows and cut when about two inches high. For use during Winter it may be sown at intervals in boxes in the greenhouse or in a frame. For a crop of seed sow in April, in drills a foot apart, and thin out moderately when about three inches high.

WIITE LONDON.-Best for salad. 5c. per oz.; r5c. per $1 / 4$ ib.; 5 oc. per lb.

BROWN OR BLACK.-More pungent in flavor than the white. 5c. per oz.; I5c. per $1 / 4 \mathrm{lb}$; $50 \mathrm{c}$. per $\mathrm{lb}$.

\section{NASTURTIUM, OR INDIAN CRESSE.}

\section{One ounce will sow 25 -foot row.}

The seeds, while young and succulent, are pickled and ased as capers. The plants are also highly ornamental; the tall variety makes an excellent screen or covering for unsightly places in the garden.

TALL NASTURTIUM.-Choice colors. 5c. per pkt.; IOc. 0z.; 25c. per $1 / 4$ lb.; 75 c. per lb.

DWARF NASTURTIUM.-Choice colors. 5c. per pkt.; r $10 \mathrm{c}$. per oz.; $25 \mathrm{c}$. per $1 / 4 \mathrm{lb}$; $75 \mathrm{c}$. per $1 \mathrm{~b}$.
OKRA, or GUMBO.

One ounce will plant 50 hills or 75-foot drill.

This vegetable is extensively grown in ine Southern States. Its long pods, when young, are used in soups, stews, etc., and are believed to be very nutritious. It is of the easiest culture, and grows freely, bearing abundantly in any ordinary garden soil. It is sown at the usual time of all tender vegetables, in drills two inches deep, setting the plants from two to three feet apart.

IMPROVED DWARF GREEN.-Early and produc. tive. 5c. per pkt.; 1 oc. per oz.; 20c. per $1 / 4$ lb.; 6oc. per $1 \mathrm{~b}$

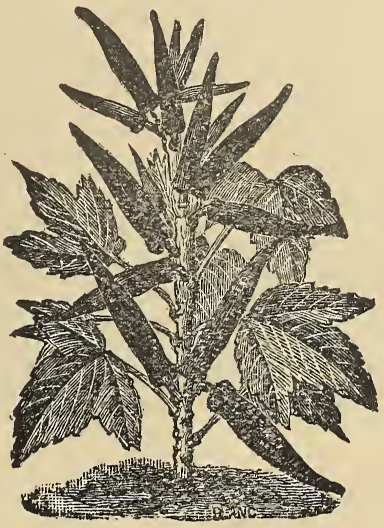

LONG GREEN.

LONG GREEN.-Long ribbed pods. 5c. per pkt.; roe. per oz.; 2oc. per $1 / 4$ lb.; 6oc. per lb.

\section{ONION}

One ounce will plant 50 hills or 75 -foot drill. Five pounds will sow an acre. For growing Large Onions, 50to 60 pounds per acre for growing sets.

The Onion thrives best in a rather strong, deep, rich, loamy soil, and, unlike most vegetables, succeeds well when cultivated on the same ground for successive years. The ground should be deeply trenched and manured the previous Autumn, and laid up in ridges during Winter to soften. As early in Spring as the ground is in work. ing order, commence operations by leveling the ground with 2 rake and tread it firmly; sow thinly in drills about a quarter of an inch deep and one foot apart; cover with fine soil and press down with the back of a spade or a light roller.

When the young plants are strong enough, thin gradually, so that they stand three or four inches apart. Keep the surface of the ground open and free from weeds by frequent hoeing, taking care not to stir the soil too deeply or to collect it about the growing bulbs.

AILSA CRAIG.-The largest of all straw-yellow onions. It is globe shaped, slightly pointed at top and base. Ioc. per pkt.; 35 c. per oz.; $\$ 1.00$ per $1 / 4$ lb.; $\$ 3.50$ per lb.

EXTRA EARLY RED.-The earliest Red Onion, fine keeper. Ioc. per pkt.; 20c. per oz.; $65 \mathrm{c}$. per $1 / 4 \mathrm{lb}$; $\$ 1.75$ per $1 \mathrm{~b}$.

EARLY PRIZE TAKER.-This Onion grows uniform in shape, of a nearly perfect globe, with thin skin, of a clean, bright siraw coior. It is of immense size, measuring from twelve to sixteen inches in circumference while under special cultivation specimens have been raised to weigh from four to six pounds. Ioc. per pkt.; I5c. per oz.; 50c. per $1 / 4$ lb.; $\$ 1.75$ per $1 \mathrm{~b}$.

SOUTHPORT WHITE GLOBE,-A handsome globular Onion of mild flavor and a good keeper; one of the very best. I I c, per pkt.; $25 \mathrm{c}$. per oz.; $75 \mathrm{c}$. per $1 / 4$ lb.; $\$ 2.25$ per $1 \mathrm{~b}$.

OHIO YELLOW GLOBE-_Rich orange in color: large, globe shape; fiat bottom. Large yielder; also a good keeper. One of the best market sort. Ioc. per pikt.; 20c. per 0z.; 65c. per $1 / 4 \mathrm{lb}$; ; $\$ \mathrm{I} .75$ per lb.

SOUTHPORT RED GLOBE.-Differs from the Southport Yellow Globe only in color. roc. per pkt.; 20c. per oz.; $65 \mathrm{c}$. per $1 / 4$ lb.; $\$ 1.75$ per lb. 


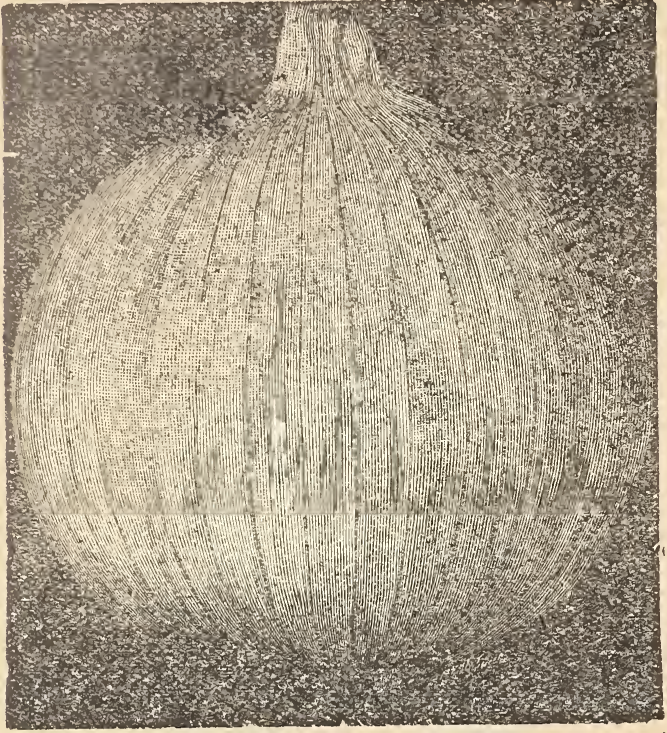

YELLOW GLOBE DANVERS.

YELIOW GLOBE DANVERS.-An excellent variety frne flavored and very productive. Ripens early and is a good keeper. Ioc. per pkt.; I 5c. per oz.; 5 oc. per $1 / 4$ lb.; $\$$ I. 50 per $1 \mathrm{~b}$

WHITE PORTUGAL, OR SILVER SKIN.-A handsome Onion, of mild flavor, but not a good keeper. Ex. tensively grown for pickling. Ioc. per pkt.; 25c. per oz.; 75c. per $1 / 4 \mathrm{lb}$.; $\$ 2.00$ per $1 \mathrm{~b}$.

WEATHERSFIELD LARGE RED.-The staple va. riety of the Eastern Onion growers. Of large size, deep in color, and an excellent keeper. Ioc. per pkt.; 20c. per oz.; 65 c. per $1 / 4$ lb.; $\$ 1.75$ per $1 b$.

SOUTHPORT YELLOW GLOBE-A favorite Yellow Globe variety in the markets of New York and Boston Solid and a good keeper. roc. per pkt.; 2oc. per oz.; 65. per $1 / 4$ lb; $\$ 1.75$ per $1 b$.

YELLOW DUTCH, OR STRASBURG.-One of the oldest varieties. The "Silver Skin" of the Eastern States. $A$ good keeper and well flavored, 5c. per pkt.; I $5 \mathrm{c}$. per z.; 50c. per $1 / 4$ lb.; $\$ 1.25$ per lb.; $\$$ I.I 5 per $1 \mathrm{~b}$. for 5 bs. or more.

\section{ONION SETS, EXTRA FINE.}

32 pounds standard weight for a bushel of onion sets. Subject to Market Fluctuation.

Yellow-I 5c. per 1b.; Ioc. per 1b., in 32 lb. lots.

Red-2oc. per lb.; I 5 c. per $1 \mathrm{~b}$ in 32 -lb. lots.

White-2oc. per 1b.; I 5 c. per lb. in $32 \mathrm{lb}$. lots.

\section{PARSLEY.}

\section{One ounce will sow 125 -foot row.}

Parsley succeeds best in rich, mellow soil. As the seeds germinate very slowly, there are four weeks elapsing sometimes before it nakes its appearance; it should be sown early in Spring, previously soaking the seeds a few hours in tepid water. Sow thickly in rows a foot apart and a half inch deep. For Winter's use protect in a frame or light cellar.

CHAMPION MOSS CURLED.-A very select stock, beautifully crimped and curled. 5c. per pkt.; I $5 \mathrm{c}$. per oz.; 25c. per $1 / 4$ lb.; 75 c. per lb.

HAMBURG, or TURNIP ROOTED.-The edible roots resemble a small parsnip, and it is esteemed for flavoring soups, stews, etc. 5c. per pkt.; I 5c. per oz.; 25c. per $1 / 4$ lb.; 75c. per $1 \mathrm{~b}$.
DOUBLE CURLED.-A fine dwarf variety, beautifully curled. Excellent for garnishing. 5c. per pkt.; T5c. per oz.; 25 c. per $1 / 4$ lb.; 75 c. per lb.

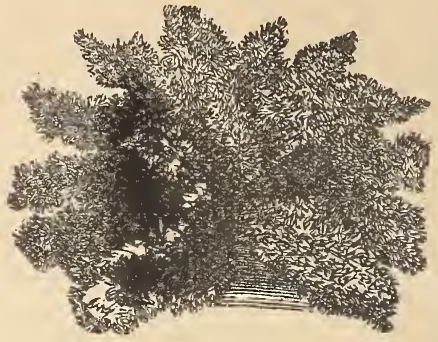

DOUBLE CURLED.

PLAIN PARSLEY.-The leaves of this sort are plain; it is hardier than the curled variety; good for flavoring. 5c. per pkt.; I 5c. per oz.; $25 \mathrm{c}$. per $1 / 4$ lb.; $75 \mathrm{c}$. por lb.

\section{PARSNIP.}

One ounce will sow I25-foot drill. Five pounds will sou an acre.

Sow as early in the Spring as the weather will admit, in drills fifteen inches apart, covering half an inch deep. When well up, thin out to five or six inches apart in the rows. Unlike carrots, they are improved by frosts, and it is usual to take up in th. Fall a certain quantity for Winter use, leaving the rest in the ground until Spring, to be dug up as required.

LONG SMOOTH, OR HOLLOW CROWN.-Best for general use. 5c. per pkt.; I5c. per oz.; 25c. per $\pi / 41 \mathrm{~b}$.; 65 c. per $1 \mathrm{~b}$.

THE STUDENT.-A fine-flavored variety. 5c. per pkt.; I 5c. per oz.; 25c. per $1 / 4$ lb.; 75c. per lb.

GURNSEY.-Half-long; becoming very popular. Ioc. per pkt.; I $5 \mathrm{c}$. per oz.; $25 \mathrm{c}$. per $1 / 4 \mathrm{lb}$; $75 \mathrm{c}$. per $1 \mathrm{~b}$.

\section{PEAS.}

60 pounds to the bushel.

One pound will plant about 50-foot row, 60 to 90 pounds will plant an acre.

Peas come earliest to maturity in light, rich soil. For general crops a deep, rich loam or a strong inclination to clay is best. For early crops, decomposed leaves or leaf. mold should be used; or, if the soil is very poor, stronger manure may be employed. For general crops, a good dressing should be applied, and for the dwarf-growing kinds the soil can hardly be too rich. When grown as : market crop, Peas are never staked, and are sown in single rows, two or three inches deep and from three to four feet apart, according to the variety or the strength of the soil. When grown in small quantities, for private use, they are generally sown in double rows, six or eight inches apart, and the tall varieties are staked up by brush. For an early crop, sow in March, as soon as the ground can be worked, and make repeated sowings every two weeks for succession. After the first of June bowing should be discontinued until the middle of August, when a good crop can sometimes be secured by sowing an early sort.

Special price given on Ioo lb. lots.

PILOT.-A large nearly smooth pea. Can be sown along with Alask and early Peas. Will produce a pod as big as Gradus and from three days to a week earlier. 8c. $1 / 4$ lb.; 30c. per lb.; 10 . lbs. $\$ 2.30$; 100 lbs., $\$ 26$.

LAXTONIA.-Vines I 8 to 20 inches high, produces an enormous crop of delicious peas just a little later than "Gradus." Vines are vigorous and can withstand adverse weather conditions easier than other large varieties. Ioc. $1 / 4$ lb.; 30c. per lb.; I0 lbs., \$2.30; 100 lbs., \$20.

BLUE BANTAM.-Extra early dwarf wrinkie Pea. Averages 15 inches high, bears enormous crops, pods deep bluish green, pods $4 \frac{1}{2}$ inches long, bear 8 to 10 peas. Pods twice the size of American Wonder and ready to pick at same time. Ioc. $1 / 4$ 1b.; 30c. per lb.; Io lbs., \$2.30; roo lbs., \$20. 
EARLY THOMAS LAXTON.-This fine early. Pea was raised by crossing "Gradus" (Prosperity) with a very early seedling of the "Earliest of All" type. It is a wrinkled marrow with a good constitution. In earliness it is within a day or two of "Earliest of All," but pods contain on the average 7 or 8 very large peas of the
richest flavor. The height is from 3 to $3 \frac{1}{2}$ feet. As a first early we consider this is the Finest Early Pea ever introdweed. IOc. $1 / 4$ lb.; 30c. 1b.; 10 lbs., \$2.30; 100 lbs. $\$ 20$.

EARLY ALASKA.-A green seeded extra early sweet Pea. Very desirable. Green, smooth Pea. 8c. 1/4 lb.; 25c. H. ; I0 lbs., \$1.80; 100 lbs., \$15.

EARLY MCLEAN'S ADVANCER.-An early green, wrinkled variety; delicious flavor; 2 feet. roc. $3 / 4$ lb.; 25c. per th.; Io lbs., $\$ 2.00$; 100 lbs., \$18.

EARLY PREMIUM GEM.-Early, hardy, prolific, uniform in habit of growth, pods borne singly on both sides of the stalk beginning near the ground; peas of the finest Gavor: about a week later than Nott's Excelsior. Seed green, wrinkled and sweet; height, I6 inches. IOc. $1 / 4$ lb.; 290. lb.; I0 lb., \$2; 100 lbs.., \$18.

EARLY NOTT'S EXCELSIOR.-Extra early dwarf wrinkle Pea. Ready for table in 40 to 50 days from planting. It grows 16 inches high, about half as tall again as American Wonder. Its even, regular habit is a great advantage to the market gardeners. This variety has come to stay, owing to its superior advantages over all other sorts. Ioc. $1 / 4$ lb.; 30c. lb.; I0 lbs., $\$ 2.30$; 100 lbs.,

EARLY GRADUS, OR PROSPERITY.-A first early Wrinkle Pea, very hardy, vigorous grower, $2 \frac{1}{2}$ feet high; pods very large and well filled; six to eight large Sweet
Peas in a pod. The great value of Gradus is its earliness. It is in the market four days after the first early. IOc. I/4 lb.; 3ec. 1b.; Io lbs., $\$ 2.30$; 100 lbs., $\$ 20$.

EARLY FIRST AND BEST.-A very early and pro ductive variety, resembling the Philadelphia Extra Early; white seoth Pea. 8c. 1/4 lb.; 25 c. per lb.; Io lbs., \$1.80; I00 Bhe, \$15.

EARLY AMERICAN WONDER.-It is one of the early wrinkled Peas; of the finest quality and wonderfully productive; its great distinctive feature, however, is its compact and dwarf growth, seldom exceeding 12 inches in heiglt, I I $1 / 4 \mathrm{lb}$; ; 30c. lb.; Io lbs., \$2.30; $100 \mathrm{lbs}$., \$18.

SECOND EARLY HEROINE. - A medium early Wrinkle Pea of medium height; pod large; very pro ductive; of excellent flavor. Ioc. $1 / 4 \mathrm{lb}$.; 30c. per 1b.; Io lbs., $\$ 2.30$; $100 \mathrm{lbs}$., $\$ 20$.

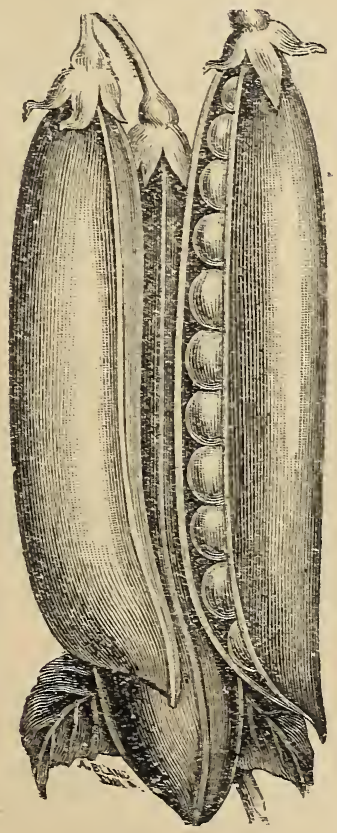

GRADUS.
SECOND EARLY JUNO.-A medium early green wrinkled Pea and one of the best of recent introduction; large, curved, showy pods; an immense cropper; Peas of fine quality; 2 to $2 \frac{T}{4}$ feet. Ioc. $1 / 4$ lb.; $30 \mathrm{c}$. 1b.; I0 $1 \mathrm{bs}$., \$2.50; 100 lbs., \$I8.

LITTLE MARVEL.-A new dwarf first early pea, good market garden variety, vine averages Is inches in height pods $2 \frac{1}{2}$ inches in length, frequently born in pairs, and contain from 6 to 7 large dark green peas whicin remain in good eatable shape for a weets later than most other varieties. Ioc. $1 / 4$ lb.; 30 c. per 1 b.; Io lbs., $\$ 2.50$; I00 lbs., \$2I.

SUTTON'S EXCELSIOR.-Resembles Nott's Excelsior, but has longer and broader pods of a light green color, I 5 inches tall, very fine for market gardeners. IOc. 1/4 lb.; 30c. per lb.; Io lbs., \$2.30; I00 lbs. \$20.

SECOND EARLY SHARP'S QUEEN.-This variety is one of the few really fine Peas that resist the long droughts which we sometimes experience. The Peas are large oval, deep green, wrinkled, and of a delicious large oval, deep green, wrinkled, and of a delicious variety, growing to about two to two and a half feet in height, and stands well under the scorching rays of the sun. I oc. $1 / 4$ lb.; 30c. 1b.; 10 lbs., \$2.30; 100 lbs., \$20.

SECOND EARLY MCLEAN'S LITTLE GEM.-A dwarf, green, wrinkled marrow; very prolific; of superior flavor, and a second early; I foot. Ioc. $1 / 4 \mathrm{lb}$. 30c. per lb.; ro lbs., $\$ 2.20$.

\section{For General Crop.}

ADMIRAL DEIVEY.-This variety is without doubt the largest podded Pea we know of. Beautifully shaped dark green pods, and peas of high-class flavor; green wrinkled; a good grower and bearer; height, $3 \frac{1 / 2}{2}$ feet. I0c $1 / 4 \mathrm{lb}$; 30c. lb.; I0 lbs., \$2.30; I00 lbs., \$18.

LONG ISLAND MOMMOTH.-Becoming a favorite with Long Island and New Jersey truckers; excellent cropper; pods large, well filled; quality excellent; peas green, wrinkled; vines 3 feet. Ioc. $1 / 4 \mathrm{lb}$; ; 30c. lb.; I lbs., \$2.30; 100 lbs., \$18.

PRINCE EDWARD.-This variety will produce pods attaining the extraordinary length of 7 inches and upward, closely packed with eleven to thirteen large dark green peas of fine flavor. Plant of branching habit growing 6 feet in height, dark green foliage, will withstand drought and mildew. Pods produced in great profusion, mostly in pairs. IOc. $1 / 4$ lb.; 30c. per 1b.; Io lbs., \$2.30; I00 lbs., $\$ 18$.

CARTER'S DAISY, OR DWARF TELEPHONE Possesses the quality of Carter's Telephone, except it grows half less in height. This makes it an exceptional valuable market sort; green, winkled. IOc. $1 / 4 \mathrm{lb}$; 3 oc. per lb.; ro lbs., $\$ 2.30$; 100 lbs., $\$ 20$.

CHAMPION OF ENGLAND,-One of the best and most popular Peas in cultivation; green, wrinkled; 4 feet. Ioc. $1 / 4$ lb.; 30c. per lb.; Io lbs., $\$ 2.20$; 100 lbs., \$Is.

DUKE OF ALBANY.-Late, remarkably hardly in growth, producing pods of large size well filled with large peas of good quality; green, wrinkled. Ioc. $1 / 4 \mathrm{lb}$; $30 \mathrm{c}$. lb. ; 10 lbs., $\$ 2.30$; 100 lbs., $\$ 20$.

SHROPSHIRE HERO.-A robust grower, about three feet, high producing long, handsome pods in abundance, well filled; flavor exquisite; green, wrinkled. We recommend it. Ioc. $1 / 4 \mathrm{lb}$; $30 \mathrm{c}$. per lb.; Io lbs., \$2.00; 100 lbs., \$i 8 .

ALDERMAN.-A large main crop pea, tall, producing long straight dark green pods five to six inches long, well filled and of excellent flavor. Vines nearly five feet high, exceedingly productive. Ioc. $1 / 4$ lb.; $30 \mathrm{c}$. 1b.; I0 lbs., \$2.20; I00 lbs., \$I 8 .

STRATAGEM IMPROVED, "FERRY STRAIN."Pea green, wrinkled; two feet; vigorous branching habit, under favorable conditions; an enormous cropper; pod long; well filled with from eight to eleven Peas of the largest size, of extra fine flavor. Ioc. $1 / 41 \mathrm{~b}$; 30c. $1 \mathrm{~b}$.; Io lbs., \$2.20; 100 lbs., \$18.

TALL TELEPHONE.-A very fine late wrinkle pea. Ioc. $1 / 4$ lb.; 30c. 1b.; 10 lbs., \$2.20; 100 lbs., \$18.

ROYAL DWARF WHITE MARROWFAT. - A favorite marrow sort; smooth, white, 4 feet. $8 \mathrm{c}$. $1 / 4 \mathrm{lb}$.; $25 \mathrm{c}$. lb.; I 5 lbs., \$300.

TALL SUGAR.-Edible pods; 5 feet. Ioc. $1 / 4 \mathrm{lb}$; $30 \mathrm{c}$. Der $1 \mathrm{~b}$. 


\section{FIELD VARIETIES.}

(6o pounds to a bushel.)

\section{Cow Peas.}

Write for special prices on large quantities. Price sub. ject to market fluctuation.

VARIOUS KINDS, MIXED-For enriching the soil and for hay. $7 \mathrm{c}$. per $1 \mathrm{~b}$.

BLACK STANDARD VARIETY.-Runner, 7c. per lb. GRAY WHIPPOORWILL.-Upright growth. 7c. per

MAMMOTH YELLOW SOJO.-6c. per $1 \mathrm{~b}$.

WILSON'S BLACK SOJO-New and extra variety. 8c. per $1 \mathrm{~b}$.

CANADA FIELD PEAS.-Sow with oats. Very val. uable for green feeding and for hay as well. $7 \mathrm{c}$. per $1 \mathrm{~b}$.

\section{PEPPER}

One ounce will produce 1,200 plants.

Grown largely for pickling. Sow in hot-bed early in April, and transplant to the open ground when the weather is favorable. They should be planted in warm, mellow soil, in rows, eighteen inches apart; between rows, 3 feet.

PIMIENTO.-Sweet variety, uniformly shaped. Green fruit, changing to red when ripe. I oc. per pkt.; $40 \mathrm{Oc}$ per oz.; $\$ 1.25$ per $1 / 4$ lb.; $\$ 4.50$ per $1 \mathrm{~b}$.

NEAPOLITAN.-Something extra fine, large fruit red color, sweet. Ripens earlier than Ruby King. Good cropper. Ioc. per pkt.; 6oc. per oz.; \$1.50 per $1 / 4 \mathrm{lb}$. $\$ 5.00$ per $1 \mathrm{~b}$.

CHAMBERS' SWEET.-Absolutely mild flavor, excel. lent producer. Not quite as blunt as "Bull Nose," medium in size, in fact, one of the best peppers we know of Ioc. per pkt.; 40c. per oz.; \$I.25 per 1/4 lb.; \$4.50 per $1 \mathrm{~b}$.

CHINESE GIANT.-The largest Pepper known. Its mammoth size, splendid shape, beautiful, rich, glossy flesh, mild flavor and enormous productiveness commend it as one of the best market varieties ever intrcduced. $20 \mathrm{c}$. per pkt.; 6oc. per oz.; \$2.00 per $1 / 4$ lb.; \$6.50 per lb.

RUBY KING.-An exceedingly large and handsome Pepper; the fruits are of a bright ruby red. From $41 / 2$ to 6 inches long by $3 \frac{1}{2}$ to 4 inches in diameter, which makes it one of the largest of Peppers. The flavor is remarkably mild, and it can be sliced and eaten with pepper and vinegar like tomatoes and cucumbers, or it can be used as a salad. I 5c. per pkt.; 50c. per 0z.; \$1.75 per $\mathrm{T} / 4$ 1D.; $\$ 5.00$ per $1 \mathrm{~b}$.

LARGE BELI, OR BULL, NOSE.-An early variety, of sharp flavor; rind thick and fleshy; color, brilliant red shape, oblong. Ioc. per pkt.; 40c. per oz.; \$I.25 per $1 / 4$ 1b.; $\$ 4.50$ per $1 b$.

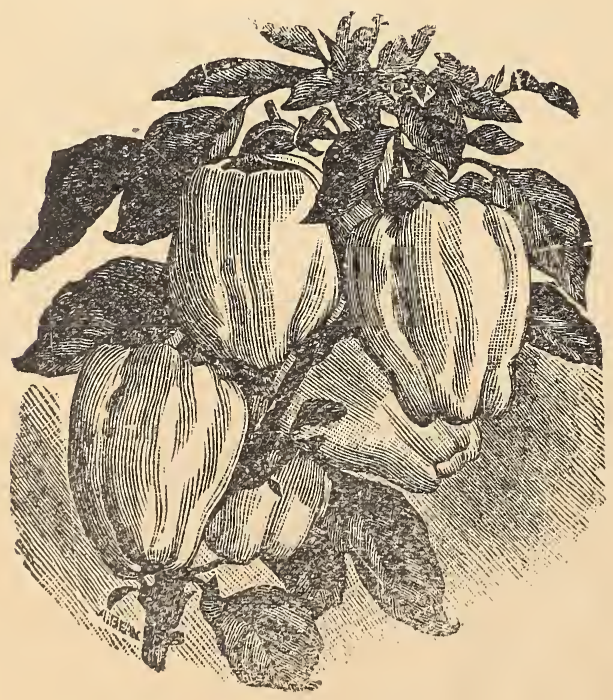

BULL, NOSE
SWEET MOUNTAIN, or MAMMOTH.-Similar to the preceding in shape and color, but larger and milder in flavor. Ioc. per pkt.; 50c. per oz.; $\$ 1.50$ per $1 / 41 \mathrm{~b}$.; $\$ 5.00$ per $1 \mathrm{~b}$.

LONG RED CAYENNL:-Fruit brilliant coral red; conical; from three to four inches in length; very productive. Ioc. per pkt.; 40c. per oz:; $\$ 1.25$ per $1 / 41 \mathrm{~b}$; $\$ 4.50$ per $1 \mathrm{~b}$.

RUBY GIANT.-A variety which is of a desirable size anl shape for stuffing. A cross of Ruby King and Chinese Giant; grows to large size and is very mild. Ioc. per pkt.; 6 oc. per oz.; \$I.50 per $1 / 4$ lb.; $\$ 5.50$ per lb.

\section{PEPPER PLANTS.}

\section{(Ready May 1st.)}

Prices Subject to Fluctuation.

RUBY KING, MOUNTAIN SWEET PIMIENTO and CAYENNE.-Out of seed-bed, I oc. per doz., 75c. per Ioo. Transplanted plants 25c. per dozen; \$I.50 per Ioo.

\section{POTATO.}

8 to $\mathrm{I} 2$ bushels will plant an acre, according to the kind of machine used, also distances planted.

The potato, like all robust-growing vegetables, can be grown with varying success on soils of all kinds and in all conditions of fertility, but the soil best suited to it is a sandy loam. In all heavy soils it is more subject to a disease, and the flavor is much inferior. In breaking up good pasture land, the decaying sod answers sufficiently well for the first year in lieu of manure. Manure is applied either in rows or hills, or broadcast over the hills and plowed in-the latter, in most cases, being preferable. If the soil is good, but little manure is required. In highly enriched soil the plants are more liable to dieease than when grown in soil that is naturally good. The best fertilizers are those of a dry, or absorbent nature, as plaster, lime, superpliosphate of lime and bone dust: for wet soil these are particularly beneficial, as they not only promote growth, but prevent diseases. Plant as early in Spring as the ground can be had in fair working order, in hills or ridges about three feet apart, coverin: in light, warm soil, about four inches deep, but in cold wet situations, two or three inches will be sufficient.

Prices not Guaranteed. Subject to Variation. $6 \mathrm{c}$ pounds to a bushel.

Special Prices Given on Large Quantities.

We handle Maine-Grown Seed Potatoes only. Seed stock grown in Maine is far superior to that grown in any other State.

SURPRISE.-An excellent quality potato. Shape and character that of Irish Cobbler. Larger in vine; also size of potato and yield; a medium early. $75 \mathrm{c}$. per peck; $\$ 2.50$ per bushel; $\$ 6.00$ per sack of 165 pounds.

STATE OF MAINE.-An excellent quality potato; heavy cropper and a good keeper. $75 \mathrm{c}$. per peck; $\$ 2.50$ per bushel; $\$ 6.00$ per barrel sack.

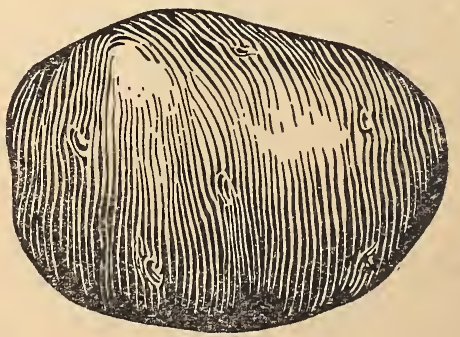

EARLY ROSE.

IRISH COBBLER.-Early, round, chunky, 85-day sort: quality of the finest; popular for home market. $75 \mathrm{c}$. per peck; $\$ 2.50$ per bushel; $\$ 6.00$ per sack of 165 outuds.

PRIDE OF THE SOUTH.-A rival to the Irish Cobbler. Shape and quality like the Irish Cobbler, but a few days earlier. $75 \mathrm{c}$. per peck; $\$ 2.50$ per bushel; $\$ 6.00$ per sack of 165 pounds. 
GREEN MOUNTAIN.-Shape, oval; white skin, big cropper and splendid cooker. 75c. per peck; \$2.50 per bushel; $\$ 6.00$ per barrel sack of 165 pounds.

HOLTON EARLY ROSE.-The leading variety for earliness, quality and productiveness. 75C. per peck $\$ 2.50$ per bushel; $\$ 6.00$ per barrel sack of 165 pounds.

\section{PUMPKIN.}

One pound will plant 250 hills.

Pumpkins are now principally cultivated for agricultural purposes. They are usually planted in fields of corn or potatoes, but may be profitably raised in fields by themselves. Sow first in May, in hills eight feet apart.

LARGE CHEESE-The best variety for cooking pur-

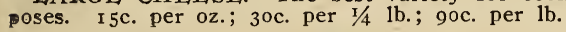

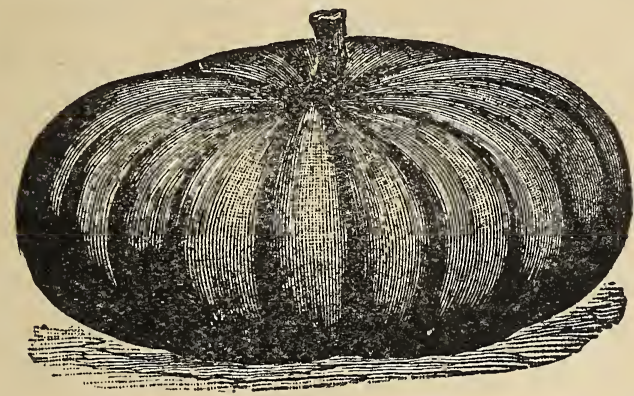

I,ARGE, CHEESE.

CONNECTICUT FIELD.-Very productive; largely rrver for feeding stock. Ioc. per oz; $25 \mathrm{c}$ per $1 / 4 \mathrm{lb}$. 75c. per $1 \mathrm{~b}$.

KING OF THE MAMMO'TH.-Grows to immense size, ofter weighing over one hundred pounds. roc. per pkt.; 20c. per oz.; 50c. per $1 / 4$ lb.; $\$ 1.50$ per $1 \mathrm{~b}$.

WINTER LUXURY.-It grows uniformly to a diameter of ten to twelve inches, and is enormously productive. It is a beautiful golden yellow, finely and closely netted, like a netted Musk Melon. As a winter keeper and cooking variety it stands unexcelled, and is one of the very best for either home use or market. Ioc. per pkt.; I5e. per oz.; 50c. per $1 / 4$ lb.; $\$$ I.50 per lb.

CUSHAW CROOKNECK.-A good all-around pumpkin. roc. per pkt.; 20c. per oz.; 50c. per $1 / 4$ lb.; $\$ 1.50$ per 1b.

SWEET POTATO TENNESSEE.-Buff yellow skin medium size oblong fruit. Flavor resembles mashed sweet potatoes. Ioc. per pkt.; 20c. per oz.; 50c. per $1 / 4$ lb.; \$1.50 per $1 b$.

\section{RADISH.}

One ounce, will sow roo feet of drill.

Kadishes thrive best in a light, rich, sandy loam; heavy or clayey soils not only delay their maturity, but produce crops much inferior in appearance and flavor. For a successive supply sow from the middle of March until September, at intervals of two or three weeks. For an early supply they may be sown in a gentle hot-bed in Februsry.

THE EARLIEST OR SAXA.-Excellent for forcing Matures in I 7 days. Color, red. 5c. per pkt.; isc. per oz.; 35c. per $1 / 4$ lb.; $\$ 1.00$ per lb.

RARLY SCARLET PRUSSIAN GLOBE.-An excellent forcer. Ioc. per pkt.; I5c. per oz.; $25 \mathrm{c}$. per $1 / 4 \mathrm{lb}$; $85 \mathrm{c}$. per $\mathrm{lb}$.

MARLY SCARLET WHITE TIP.-So rapid in growth $2 s$ to derelop in 20 days. Grows round and very symmetrical and uniform in shape; color, a bright scarlet, white tip. roc. per pkt.; 15c. per oz.; $25 \mathrm{c}$. per 1/4 lb.; 75c. per ib.
CRIMSON GIANT TURNIP.-Will grow to an un usually large size. It is always tender, crisp and of mild flavor. It remains in perfect condition a long time. Color, a beautiful crimson. It will force well, but it is especially adapted for outdoor growing. roc. per pkt.; I5c. per oz.; $25 \mathrm{c}$. per $1 / 4 \mathrm{lb}$.; $85 \mathrm{c}$. per $\mathrm{lb}$.

CHARTIER, OR LONG ROSE.-Decidedly distinct in appearance from any radish in at the top is crimson, running into pink about the middle,
and from thence downward it is pure waxy white. It will attain a very large size before it becomes unfit for table. 5c. per pkt.; I5c. per oz.; 25c. per $1 / 4 \mathrm{lb}$; $75 \mathrm{c}$ per $1 \mathrm{~b}$

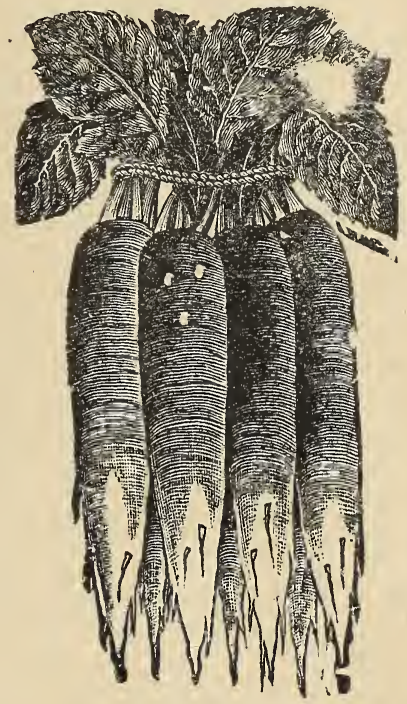

LONG ROSE.

EARLY FELTON WHITE BOX.-It is perfectly round, smooth skin, pure white, free from all sharpness or bitterness. A remarkably quick grower, with small top. For forcing it is in every way superior. 5c. per pkt.; I 5 c. per oz.; 25 c. per $1 / 4$ lb.; 85 c. per lb.

EARLY WHITE TURNIP.-Same as the Early Felton White Box, only different in color. 5c. per pkt.; I5c. per oz.; $25 \mathrm{c}$. per $1 / 4 \mathrm{lb}$; $75 \mathrm{c}$. per $1 \mathrm{~b}$.

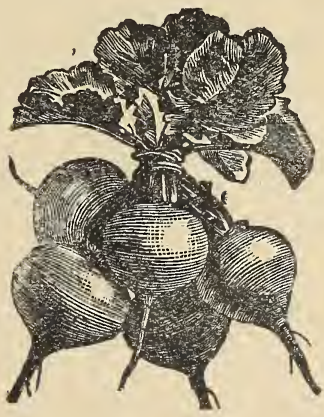

THE EARLIEST OR SAXA.

EARLY LONG WHITE ICICLE.-The flavor of this new sort is very mild, and it is invaluable for slicing. The top s short; flesh very crisp and tender; very attractive when bunched. It matures in 40 days from time of sowing the seed, and remains in prme condition for eating for fully two weeks. Ioc. per pkt.; 15c. per oz.; 25 c. per $1 / 4$ lb.; 75 c. per $1 \mathrm{~b}$.

EARLY LONG SCARLET SHORT TOP.-The standard variety for market and private gardens. $5 \mathrm{c}$. per pkt.; I5c. per oz.; $25 \mathrm{c}$. per $1 / 4 \mathrm{lb}$; $75 \mathrm{c}$. per $1 \mathrm{~b}$. 
EARLY SCARLET TURNIP.-Very delicate in flavor; one of the best early sorts. 5c. per pkt.; I5c. per oz.; $25 \mathrm{c}$. per $1 / 4 \mathrm{lb}$; $75 \mathrm{c}$. per $1 \mathrm{~b}$.

FRENCH BREAKFAST.-A variety of quick growth; very mild and tender. 5c, per pkt.; roc. per oz.; $25 \mathrm{c}$. per $1 / 4 \mathrm{lb}$; $75 \mathrm{c}$. per $1 \mathrm{~b}$.

LONG PINK, OR LADY FINGER. - Like the white, only differs in color. 5c. per pkt.; I5c. per oz.; 35c. per $1 / 4 \mathrm{lb}$; $\$ \mathrm{I} .00$ per $1 \mathrm{~b}$.

LONG WHITE VIENNA OR LADY FINGER.This is the finest Long White Radish in cultivation, most beautiful in shape; skin and flesh are pure snow white, crisp and of rapid growth. 5c., ler pkt.; 15 . per oz.; 35c. per $1 / 4$ lb.; $\$ \mathrm{I} .00$ per $1 \mathrm{~b}$.

STRASBURG WHITE.-Suitable for market and private gardens. It is of the tapering shape; both skin and flesh white. It is an excellent Summer variety, being tender and crisp and of fine flavor and a quick grower. c. per pkt.; I5c. per 0z.; 35c. per $1 / 4 \mathrm{lb}$; $\$ 1.00$ per lb.

ROSE CHINA WINTER.-Bright rose color; flesh firm and piquant. Excellent for Winter use. 5c. per pkt.; 15c. per oz.; 30c. per 1/4 lb.; $\$ 1.00$ per lb.

WHITE SUMMER TURNIP.-Large white; excellent for Summer use; very good market sort. $5 \mathrm{c}$. per pkt.; I 5 c. per oz.; 30c. per $1 / 4 \mathrm{lb}$; $\$ \mathrm{I} .00$ per $1 \mathrm{~b}$.

BLACK SPANISH LONG.-One of the hardiest and best for Winter use. 5c. per pkt.; roc. per oz.; 25c. per $1 / 4$ lb.; $75 \mathrm{c}$. per $1 \mathrm{~b}$.

WHITE SPANISH.-Rather milder in flavor than the preceding. 5c. per pkt.; roc. per oz.; 30c. per $1 / 4$ lb.; $\$$ r.00 per $1 \mathrm{~b}$.

BLACK SPANISH ROUND.-Good keeper. 5c. per pkt.; I oc. per oz.; 30c. per $1 / 4 \mathrm{lb}$; $\$ 1.00$ per $1 \mathrm{~b}$.

\section{RHUBARB.}

VICTORIA.-Cherry red in color, stalks immense, cook splendidly, are not stringy. Ioc. per pkt.; I5c. per oz.; 35 c. per $1 / 4$ lb.; $\$ 1.50$ per lb.

\section{SALSIFY, OR OYSTER PLANT.}

One ounce will sow 50 feet of drill.

The Oyster Plant succeeds best in light, well-enriched, mellow soil, which, previous to sowing the seed, should be stirred to a depth of eighteen inches. Sow early in the Spring, in drills fifteen inches apart; cover the seed with fine soil an inch and a half in depth, and when the plants are strong enough, thin out to six inches apart. SALSIFY, OR OYSTER PLANT.-5c. per pkt.; $20 \mathrm{c}$ per oz.; 50c. per $1 / 4$ lb.; $\$ 1.50$ per lb.

\section{SEA KALE.}

One ounce wll sow Ioo feet of drill.

Cultivated for its blanched shoots, which are cooked as asparagus. A supply may be had all Winter by planting the roots closely in a warm cellar before frost. Sow one inch, in drills two feet apart. Thin out to six inches, and the next Spring plant in hills three feet apart. Ioc. per pkt.; $25 \mathrm{c}$. per oz.

\section{SORREL.}

LARGE LEAVED.- - Has large leaves, can be cut five or six times, perfectly hardy. Leaves light green, quality very fine and not as broad as Spinach leaves. Ioc. per pkt.; 20c. per oz.; 50c. per $1 / 4$ lb.; $\$$ I.50 per lb.

\section{SPINACH.}

Notice.-Owing to market conditions, all prices on Spinach are subject to change without notice.

One ounce will sow 75 feet of drill, 8 pounds will sow an acre.

This is a very important crop in our market gardens; it is one of the most easily managed of all vegetables, re quiring but little culture, and may be had fit for use one entire season. The main crop is sown in September. It is cometimes covered up, in exposed places, with straw or salt hay during the Winter, which prevents it from be Ing cut with the frost, but in sheltered fields here there is no necessity for covering. For summer use it may be is no necessity for covering. For summer use it may be August. Spinach is best developed, and most tender and succulent. when grown in rich snil

BLOOMSDALE SAVOY GENUINE.-The best market sort. 5c. per pkt.; 8c. per oz.; 15c. $1 / 4$ lb.; $35 \mathrm{c}$. per lb.; Io lbs., $\$ 2.50$.
LARGE, ROUND THICK-LEAVED VAROFLAY.A new variety, with very large, thick leaves. 5c. per pkt.; 8c. per oz.; I 5c. per $1 / 4$ lb.; 35c. per $1 \mathrm{~b}$.

NORFOLK SAVOY LEAVED.-The leaves are numerous, succulent, curled and wrinkled like a Savoy Cabbage. It produces nearly twice the weight or crop as the ordinary sorts, and is also the hardiest of all the varieties of Spinach. 5c. per pkt.; 8c. per oz.; i5c. per $1 / 4 \mathrm{lb}$.; 35c. per $1 b$.

VICTORIA.-Leaves extra dark, black-green color. One of the best Winter sorts. 5c. per pkt.; $8 \mathrm{c}$. per oz.; I 5 c. per $1 / 4$ lb.; 35c. per lb.

NEW ZEALAND. - This variety endures heat and is the best for summer growing. 5c. per pkt.; roc. per oz.; I5c. per $1 / 4 \mathrm{lb}$.; $75 \mathrm{c}$. per $1 \mathrm{~b}$.

LONG STANDING OR ALL SEASON.-Leaves large thick and crimped, with a fleshy appearance, hardy, and one of best varieties for autumn and spring sowing. $5 \mathrm{c}$. per pkt.; 8c. per oz.; I 5c. per $1 / 4$ lb.; 35c. per $1 \mathrm{~b}$.

\section{SQUASH.}

Among Early Brush Sorts one ounce of seed will plant 50 hills; one ounce of Trailing Varieties 20 hills.

Squashes are of luxuriant and vigorous growth, and, although they will grow readily on almost any soil, they will well repay generous treatment. Like all vegetable of this class, it is useless to sow until the weather has be come settled and warm. Light soils are best suited for their growth, and it is most economical of manure to prepare hills for the seeds in ordinary manner by incor. porating two or three shovelfuls of well-rotted manure with the soil for each hill. For the bush varieties, from three to four feet each way, and for the running sorts, from six to eight feet. Eight or ten seeds should be sown to each hill, thinning out after they have attained their rough leaves, leaving three or four of the strongest plants.

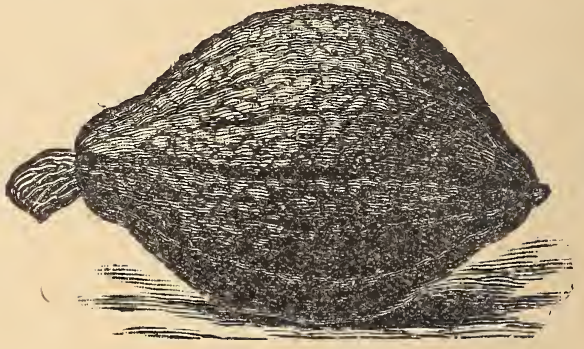

BOSTON MARROW.

WHITE BUSH SCALLOPED.-An early market variety; excellent for shipping. 5c. per pkt.; 15c. per oz.; 40c. per $1 / 4$ lb.; $\$ 1.25$ per $1 b$.

HUBBARD.-A general favorite and more largely grown as a late sort than any other; of large size; flesh fine grained, dry and of excellent flavor. $5 \mathrm{c}$. per pkt.; I5c. per oz.; 50c. per $1 / 4$ lb.; $\$$ I.50 per lb.

BUSH SUMMER CROOK-NECK.-Early productive and of good quality; fruit orange-yellow, covered with warty excrescences. 5c. per pkt.; I 5 c. per oz.; 50 c. per $1 / 4$ lb.; $\$ 1.50$ per $1 b$.

WINTER CROOK-NECK.-A variety largely grown in some of the Eastern States; flesh close grained, sweet and fine flavored. Plant in hills nine feet apart. $5 \mathrm{c}$. per pkt.; I5c. ner oz.; 35c. per $1 / 4 \mathrm{lb}$.; $\$ 1.25$ per $1 \mathrm{~b}$.

BOSTON MARROW.-A much-esteemed variety, coming about ten days later than the bush sorts; a good keeper, and of unsurpassed flavor. $5 \mathrm{c}$. per pkt.; $15 \mathrm{c}$. per oz.; 3oc. per $1 / 4$ lb.; $\$ 1.00$ per $1 \mathrm{~b}$.

MAMMOTH CHILL.-Grows to large size, often weighing over two hundred pounds. Excellent for all uses. 5c. per pkt.; I5c. per oz.; 50c. per $1 / 4$ lb.; $\$ 1.50$ per $1 \mathrm{~b}$.

GOLDEN CUSTARD.- It is yellow in color and excellent fine flavor; grows to good size, and of a very fine quality; very productive and of a bushy nature. 5c. per pkt.; I 5c. per oz.; 35c. per $1 / 4$ lb.; $\$ 1.00$ per $1 \mathrm{~b}$.

VEGETABLE MARROW.-Long greenish white variety, very sweet and tender; fine for cooking. 5c. per pkt.; I 5 c. per oz.; 50c. per $1 / 4$ lb.; $\$ 1.50$ per $1 \mathrm{~b}$.

\section{SWISS CHARD.}

GIANT LUCLLI.IS.-Crinkly leaf, tall growing variety. Enormous yielder. Culture same as beet. 5c. per pkt.; roc. per oz.; $25 \mathrm{c}$. per $1 / 4$ lb.; $75 \mathrm{c}$. per $1 \mathrm{~b}$. 
TOBACCO SEED.

IMPORTED HAVANA.-40c. per oz.; \$3.50 per lb.

\section{TOMATO.}

One ource will produce about 1,200 plants.

This delicious vegetable is one of the most important of all garden products. The seed should be sown in a hot-bed, about the first of March, in drills five inches apart and half an inch deep. When the plants are about two inches high they should be set out, four or five inches apart, in another hot-bed, or removed into small inches apart, in another hot-bed, or removed into small times transplanted a second time into larger pots, by which process the plants are rendered more sturdy and branching. About the middle of May the plants may be set in the open ground. They are planted for early crops on light, sandy soil, at a distance of three feet crops in hills in which a good shovelful of rotted manure bas been mixed. On heavy soils, which are not suited to an early crop, they should be planted four feet apart. Water freely at the time of transplanting, and shelter from the sun for a few days until the plants are estab lished. Sufficient plants for a small garden may be started by sowing a few seeds in a shallow box or flowering.pot and placing it in a sunny window of the room or kitchen.

JOHN BAER.-Early, the first tomato to fruit in the garden. Plants dwarf, fruit of medium size, red and very uniform. roc. per pkt.; $35 \mathrm{c}$. per oz.; $\$ 1.25$ per $1 / 4 \mathrm{lb}$.; $\$ 4.00$ per $1 \mathrm{~b}$.

BONNY BEST.-An extra early, bright red tomato, smooth, large and productive. Ioc. per pkt.; $25 \mathrm{c}$. per oz. 85 c. per $1 / 4 \mathrm{lb}$; $\$ 3.00$ per $1 \mathrm{~b}$.

PONDEROSA.-The largest tomato in cultivation, very solid and fine cropper. Ioc. per pkt.; 40c. per oz.; \$1.50 per $1 / 4 \mathrm{lb}$; $\$ 5.00$ per ib.

MATCHLESS.-Large red fruit, general crop variety, good yielder. Ioc. per pkt.; $25 \mathrm{c}$. per oz.; $85 \mathrm{c}$. per $1 / 4 \mathrm{lb}$. $\$ 3.00$ per $1 \mathrm{~b}$.

GREATER BALTIMORE.-This variety is one of the largest and most perfectly shaped varieties in cultivation. Ripens evenly and early, and holds its size to the end of the season. It is very prolific, has few seeds, solid flesh, a good canning variety and bears shipping long distances. I oc. per pkt.; $25 \mathrm{c}$. per oz.; $85 \mathrm{c}$. per $1 / 4 \mathrm{lb}$; $\$ 3.00$ per lb.

RED ROCK.-A very red, attractive variety. It ripens very evenly. It is coreless and has a very red interior. It is smooth, solid and is a very heavy cropper. Ioc. per pkt.; 25c. per oz.; 85 c. per $1 / 4 \mathrm{lb}$.; $\$ 3.00$ per $\mathrm{lb}$.

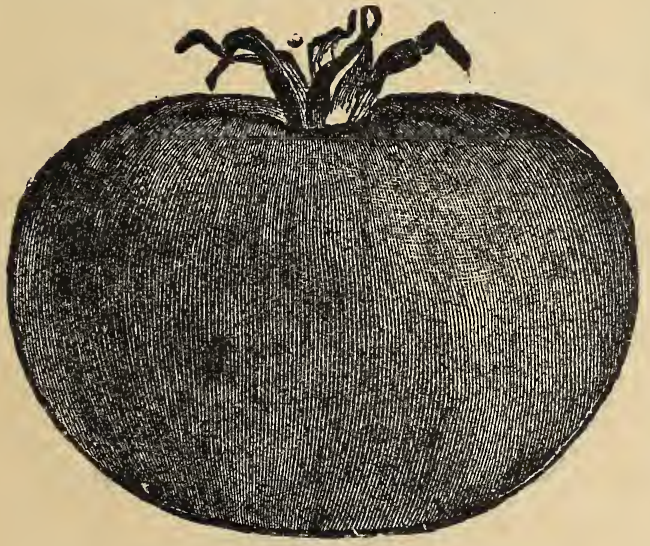

STONE

STONE (Selected Strain).-Very large, perfectly smooth, bright scarlet, solid; very productive; valuable for market gardeners and canners. Ioc. per pkt.; $25 \mathrm{c}$ per oz.; 75c. per $1 / 4 \mathrm{lb}$.; $\$ 2 ., 0$ per $1 \mathrm{~b}$.
LIVINGSTON'S BEAUTY.-A popular variety. The color is a glossy crimson, with a purple tinge. It grow in clusters of four and five, retaining its large size late in the season. Very solid, with a tough skin, making it very desirable for shipping. 1oc. per pkt.; 25c. per oz.; $85 \mathrm{c}$ per $1 / 4$ lb.; $\$ 3.00$ per $1 b$.

SPARK'S EARLIANA.-The earliest smooth Red Tomato of good size and flavor now in cultivation. It is very compact grower, and consequently can be planted onethird closer than any other early sort. If you grow early Tomatoes don't miss planting it. It is a wonder. Ioc. per pkt.; $25 \mathrm{c}$. per oz.; $85 \mathrm{c}$. per $1 / 4 \mathrm{lb}$.; $\$ 3.00$ per lb.

ACME. - The fruit is of a medium size, perfectly smooth and regular in shape, very solid, and a great bearer; colo quite distinct, being a dark red, with purplish tinge IOC. per pkt.; 30c. per oz.; $\$ 1.00$ per $1 / 4$ lb.; $\$ 3.50$ per ib.

YELLOW PLUM.-A beautiful variety. Used principally for pickling. Ioc. per pkt.; 35c. per oz.; $\$ 1.25$ per $1 / 4$ lb.; $\$ 4.00$ per lb.

RED CHERRY.-A small, early variety; size and shape of a cherry. For pickling. roc. per pkt.; $35 \mathrm{c}$. per oz.; $\$ 1.25$ per $1 / 4$ lb.; $\$ 4.00$ per $1 \mathrm{lb}$.

\section{TOMATO PLANTS.}

\section{(Ready May 1st.)}

EARLY EARLIANA, PERFECTION AND S'TONE TRANSPLANTED PLANTS.-15c. to $25 \mathrm{c}$. per doz.; $\$ 1.00$ to $\$ 1.50$ per 100; $\$ 7.50$ to $\$ 10.00$ per 1,000 , according to stockiness of plants. $75 \mathrm{c}$. per dozen grown in 3 -inch pots; in boxes roc. each; $\$ 1.00$ per doz.

LATE STONE AND GREATER BALTIMOREField grown, $\$ 3.50$ per $\mathrm{I}$, ooo

EXTRA STRONG GROWN PLANTS.-In flats. special prices.

TRANSPLANTED

\section{TURNIP.}

One ounce will sow I25 feet of drill; I I/2 to 2 lbs. will sow an acre.

Turnips do best on highly-enriched, light, sandy or gravelly soil. Commence sowing the earliest varieties in April, in drills from twelve to fifteen inches apart, and thin out early to six or nine inches in the rows. For succession, sow at intervals of a fortnight until the last week in July, from which time until the end of August sowings may be made for the Fall and main crops. Tur. nips may be preserved until Spring by cutting off the tops about one inch from the bulb, and storing in a cellar or cool shed during Winter, covering the roots with dry sand; they should be harvested before severe frost set in, for, though comparatively very hardy, few of the varieties will survive the Winter of the Northern States in the open ground.

YELLOW ABERDEEN.-Very hardy and productive good keeper, globe-shaped, color pale yellow, with purple top; very firm in texture, and closely resembles the Ruta Baga in good keeping qualities; good either for table or stock. 5c. per pkt.; I oc. per oz.; I5c. per $1 / 4 \mathrm{lb}$.; $50 \mathrm{c}$. per lb.

WHITE EGG.-Flesh very firm and fine-grained, thin and perfectly smooth skin, and both flesh and skin are of snowy whiteness. 5c. per pkt.; I5c. per oz.; $25 \mathrm{c}$. per $1 / 4$ lb.; $75 \mathrm{c}$. per $1 \mathrm{~b}$.

YELLOW GLOBE.-One of the best American varie ties for general crop. Flesh very firm and sweet, and keeps well until late in Spring. Grows to a large size, and is excellent both for stock and table use. 5c. per pkt.; roc. per oz.; I 5 c. per $.1 / 4$ lb.; 5 oc. per lb.

EARLY FLAT DUTCH.-An excellent variety, resembling White Strap Leaf. The best variety for Spring sowing. 5c. per pkt.; Ioc. per oz.; $25 \mathrm{c}$. per $1 / 4$ lb.; $85 \mathrm{c}$. per lb.

EARLY SNOWBALL.-A medium-sized, round, pure, white variety, of excellent flavor. For early sowing this is one of the best, being crisp, tender and sweet. Maturing in about six weeks from time of sowing. 5c. per pkt.; 15c. per oz.; 20 . per $1 / 4$ lb.; 65 c. per $1 \mathrm{~b}$. 
YELLOW-STONE.-Bulbs of medium size, very firm, excellent flavor and good keeper; one of the best and most popular yellow-fleshed varieties for table use; it is equally good for feeding stock. 5c. per pkt.; roc. per oz.; 20c. per $1 / 4$ lb.; 65 c. per lb.

RED-TOP STRAP LEAF.-Rapid grower and mild flavor; the popular variety for early use, either for the table or stock. 5c. per pkt.; roc. per oz.; I 5c. per $1 / 4$ lb.; 4 oc. per lb.

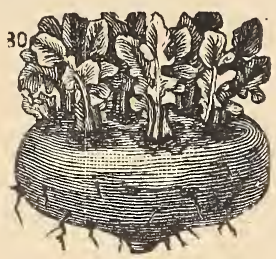

PURPLE-TOP STRAP LEAF.

PURPLE-TOP WHITE GLOBE.-An early variety, globe-shaped, in other respects similar to the Red-Top gtrap Leaf, A handsome-looking bulb, and is rapidly taking the lead of all other varieties of early Turnip for market garden purposes. 5c. per pkt.; roc. per oz.; i $5 \mathrm{c}$. per $1 / 4 \mathrm{lb}$.; $40 \mathrm{oc}$. per $1 \mathrm{~b}$.

GOLDEN BALL (ROBERTSON'S).-Rapid grower, excellent flavor, globe-shaped, and of a beautiful bright yellow color; a good keeper, and has no superior for table use. $5 \mathrm{c}$. per pkt.; 10c. per oz.; I5c. per $1 / 4 \mathrm{lb}$; ; $50 \mathrm{c}$. per $1 \mathrm{~b}$.
RUTA BAGA, RUSSIAN OR SWEDISH TURNIP.

The Ruta Baga, Russian or Swedish Turnip, is excensively grown for a farm crop. The roots are close grained, very hard, and will endure a considerable degree of cold without injury. The roots are best preserved in a pit or cellar during the Winter, and are excellent for the table early in Spring. Sow from 2oth of June to the middle of July, in drills two feet apart, and thin out to eight inches.

IMPROVED AMERICAN (PURPLE-TOP). - The leading variety, very hardy and productive. Flesh yellow, solid, sweet and fine'y flavored. Equally good for stock or table use. The principal variety raised by market gardeners. 5c. per pkt.; Ioc. per oz.; 20c. per $5 / 4$ lb.; 6oc. per $1 \mathrm{~b}$.

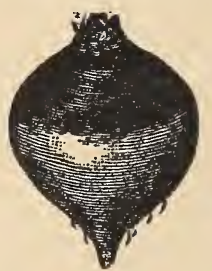

AMERICAN PURPLE-TOP.

COW HORN.-A long white turnip. Grows to large size; it has a fine desirable flavor and is a heavy cropper. 5c. per pkt.; 10c. per oz.; 35c. per $1 / 4$ lb.; 65c. per $1 \mathrm{~b}$.
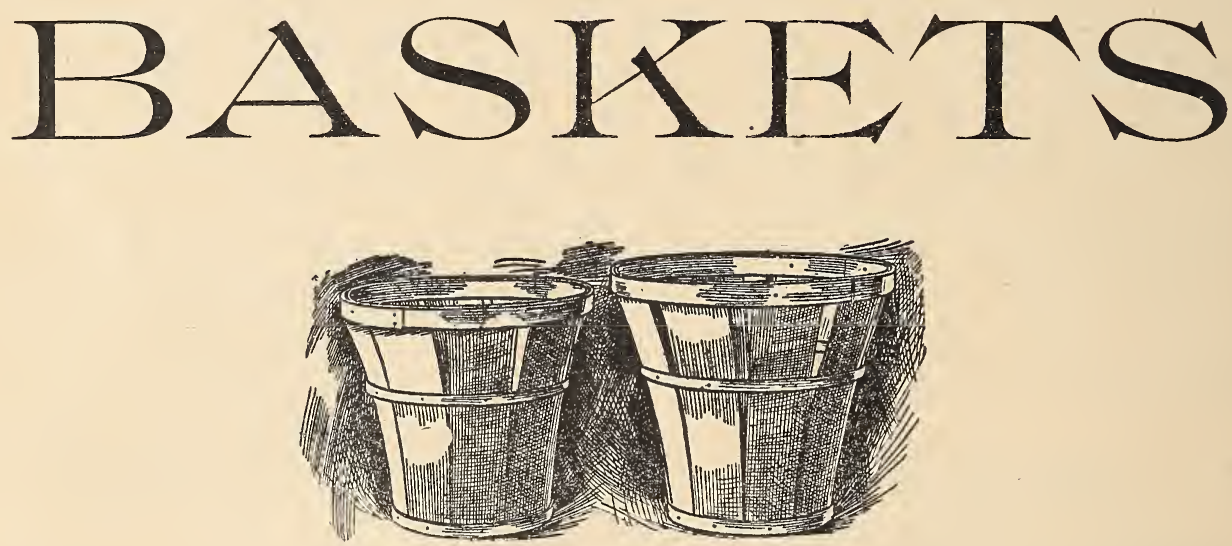

RIBSAM always has the Baskets you want

Splint Baskets, 4-quart, 8=quart, 16-quart, 20-quart Wood or Wire Bound

Berry Boxes, Oak and Bamboo Baskets

Handle Baskets, $1 / 4=$ bushel, $1 / 2=$ bushel, $5 / 8=$ bushel, I-bushel, $2=$ bushel Berry Baskets Egg Baskets 


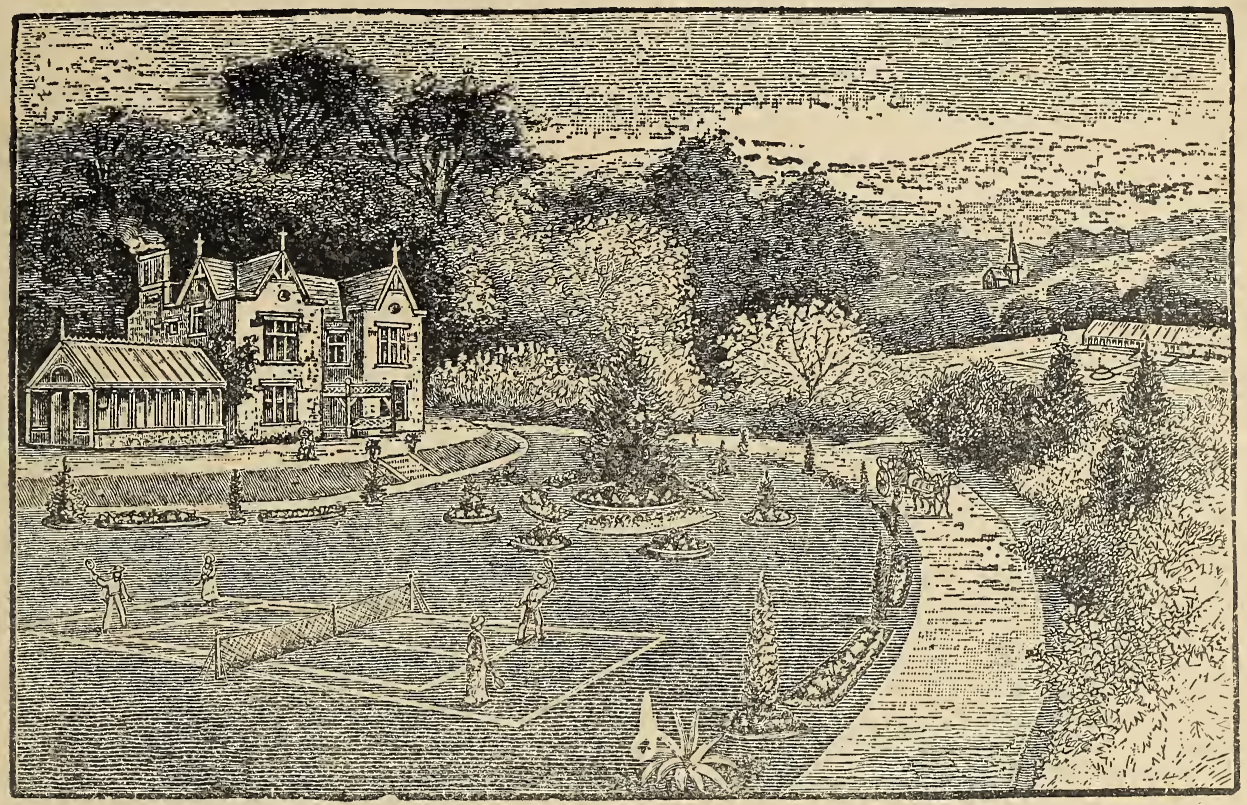

\section{Lawn Grass Seeds}

The preparation for laying down lawns is too often hastily and imperfectly made. The first point is to get the ground shaped to the desired grade, taking care in grading that when the hills are removed sufficient subsoil is also removed, to be replaced with top soil, so that at least six inches of good soil will overlay the whole in all places. When the grading is finished, drains should be laid wherever necessary; then the whole should be thoroughly plowed, a subsoil following in the wake of the common plow, until it is completely pulverized. A heavy harrow should then be applied, until the surface is thoroughly fined down. All stones, roots, etc., should be removed, so that a smooth surface may be obtained. The lawn is now ready to be sown. When the seed is sown, a light so that a smooth surface may be obtained. The lawn is now ready to be sown. When the seed is sown, a light
harrow should be again appliea, and after a thorough rolling given, so that the surface is made as smooth as possible. In the latitude of New York the seed may be sown at any time during the months of April and May, and will form a good lawn by August, if the preparation has been good. If sown in the hot months of June or July, a sprinkling of oats should be sown at the same time, so that the shade given by the oats will protect the young grass from the sun. For small plots, of course, digging, trenching and raking must be done, instead of plowing, subsoiling or harrowing. If by mail, add five cents per $l b$. for first pound and one cent for each additional pound thereafter.

RIBSAM CHOICE LAWN GRASS.-This is composed of choice selected grasses, of neat compact growth, and will produce fine sward. $40 \mathrm{c}$. per lb.; Io lbs., $\$ 3.50$ 20 lbs., $\$ 6.50$; roo lbs., $\$ 30.00$; I qt., $30 \mathrm{co}$; 4 qts., $\$$ I.00; peck, $\$ 1.75$; bushel (of 20 lbs.), $\$ 6.50$.

(For forming new Lawns, about seventy-five pounds per acre are required.)
LAWN GRASS, FOR SHADE.-Fine mixed, $45 \mathrm{c}$. per lb.; ro lbs., \$4.00.; 20 lbs., $\$ 7.50$; roo lbs., $\$ 35.00$ I qt., 35 c.; 4 qts., $\$ 1.25$; peck, $\$ 2.25$; bushel (of 20 lbs.), $\$ 7.50$.

\section{Ribsam's Lawn Fertilizer}

It is far superior to lump, straw manure, which disfigures the lawn with filthy materials, giving off an offen. sive odor, and is less expensive than manure; the cost of the Dressing being less, in many cases, than the cost of applying stable manure. It is odorless, and is so clean that anyone can apply it: It contains no weed seeds found always in manure, and which are the pests of the lawn This is so prepared that it acts gradually through the seasons, producing a luxurious growth of grass of rich green color. It may be applied at any time during the Spring and Summer, or Autumn, or as often as the grass seems to need nourishment. One lb. to ro square feet, or 500 lbs. to an acre. Price, 6c. per lb.; per bag of ro lbs., 50c.; per 25 lbs., $\$ 1.00$; per 10o lbs., $\$ 3.75$; per ton, $\$ 55.00$.

SHEEP MANURE.-6c. per lb.; 5 lbs., 25c.; Io lbs., 45c.; 25 lbs., \$1.00; 100 lbs., \$3.25.

BONE, PURE, GROUND.-6c. per lb.; 5 lbs., 25c.; Io lbs., 45c.; 25 lbs., $\$$ r.0o; Ioo lbs., $\$ 3.50$.

\section{Pulverized Lime Stone (For the Lawn)}

I0 lbs. spread Ioo square feet (IO X IO); I oo lbs. will spread I,00o square feet $(20 \times 50)$.

Prices, to lb. bags, $25 \mathrm{c}$.; 25 lbs., 40c.; 50 lbs., 65c.; I00 lb. bag, $\$ 1.00$.

\section{Limoid Hydrated (For Lawn and Vegetable Garden)}

Prices, to lb. bag, 25c.; 25 lbs., 50c.; 50 lbs., 75 c.; 100 lbs., \$1.25. 


\begin{tabular}{|l|l|l|l|}
\hline $\begin{array}{l}\text { Prices Subject to } \\
\text { Market Fluctuations }\end{array}$ & If erem Special Prices on \\
\hline
\end{tabular}

\section{Grass and Grain Seeds.}

If there is anything you specially want that we have not in our Catalogue, write to us for in. formation and prices, which will promptly be given to you.

\section{BARLEY.}

48 pounds to a bushel.

BARLEY.-Six and eight-rowed. \$2.25 per bushel.

\section{BUCKWHEAT.}

48 pounds to a bushel.

NEW JAPANESE.-Kernel twice the size of the ordinary variety. It is earlier and more productive. Flour very fine. $\$ 2.00$ per bushel.

\section{GRA8S SEED.}

HERD, OR RED TOP GRASS (Agrostis Vulgaris.)Natural harvest seed in hull. Valuable as a mixture in either pasture or lawn grasses. Succeeds well in almost any soil. Best adapted to neat soil. Sow 20 to $30 \mathrm{lbs}$. to an acre. $25 \mathrm{c}$. per lb.; $15 \mathrm{lb}$. lots and over, 22c. per lb.

HERD OR RED TOP GRASS SEED.-Fancy seed thrashes out of hull. Sow 10 to 15 lbs. to an acre. $45 \mathrm{c}$. per lb.; $15 \mathrm{lbs}$. and over, $40 \mathrm{c}$. per $\mathrm{lb}$.

KENTUCKY BLUE GRASS (Poa Pratennis).-Sow 30 to $35 \mathrm{lbs}$, to an acre. It is also known as June Grass. 30 to $35 \mathrm{lbs}$. to an acre. It is also known as June Grass. grasses. Thrives best in dry soils, and retains its verdure during the hottest weather. Extra-clean seed. $65 \mathrm{c}$. per $\mathrm{lb}$; ; $15 \mathrm{lb}$. lots and over, $58 \mathrm{c}$. per $\mathrm{lb}$.

PERENNIAL RYE GRASS (Lulium Perenne).-Sow 30 to $35 \mathrm{lbs}$. to an acre. A very nutritious and valuable grass for meadows and permanent pastures. 2oc. per lb.; ${ }_{5} \mathrm{lb}$. lots and over, $15 \mathrm{c}$. per $\mathrm{lb}$.

RHODE ISLAND BENT GRASS (Agrostis Canina). -Sow 20 to $30 \mathrm{lbs}$. to an acre. One of the finest of grasses for lawns when sown alone. $75 \mathrm{c}$. per $1 \mathrm{~b}$.

CREEPING BENT GRASS.-Sow 20 to $30 \mathrm{lbs}$. to an acre. One of the best putting green grasses. Lays close to the ground and withstands drought better than any other blade grass. $75 \mathrm{c}$. per $\mathrm{lb}$.

ORCHARD GRASS (Dactylis Glomerata). Sow 20 to $25 \mathrm{lbs}$. to an acre. - One of the most desirable of all pasture grasses. Especially valuable for grazing stock. $35 \mathrm{c}$. per lb.; I 5 lb. lots and over, 30c. per lb.

TIMOTHY GRASS (Phleni, Pratense). Sow 10 to 15 1bs. to an acre.-This well-known variety is extensively grown throughout this country. It will produce a larger crop than any other fine blade grass for hay. 20c. per lb.; $15 \mathrm{lb}$. lots and over, 12c. per $1 \mathrm{~b}$.

HUNGARIAN GRASS (Panicum Germanicum). Sow 50 to 60 lbs. to an acre. - Early. Height, two or three feet; abundant foliage and slender head; withstands drought and yields well on light soil. I5c. per lb.; is lb. lots, 9c. per lb.

GERMAN, OR GOLDEN MILLET. Sow 50 to $60 \mathrm{lbs}$. to an acre.-Medium early. In height, three to four feet; heads closely condensed. Ioc. per $1 \mathrm{~b}$.; I $_{5} \mathrm{lb}$. lots and over, 5c. per lb.

\section{CLOVER8.}

Prices Variable.

ALFALFA, OR LUCERNE, Sow 20 to $30 \mathrm{lbs}$ to an acre.-It requires a deep, rich soil, and in such will produce several crops every season. One of the best green fodder plants. 30c. per lb.; I5 lb. lots, $\$ 3.75 ; 100 \mathrm{lb}$. lots, $\$ 22.00$.

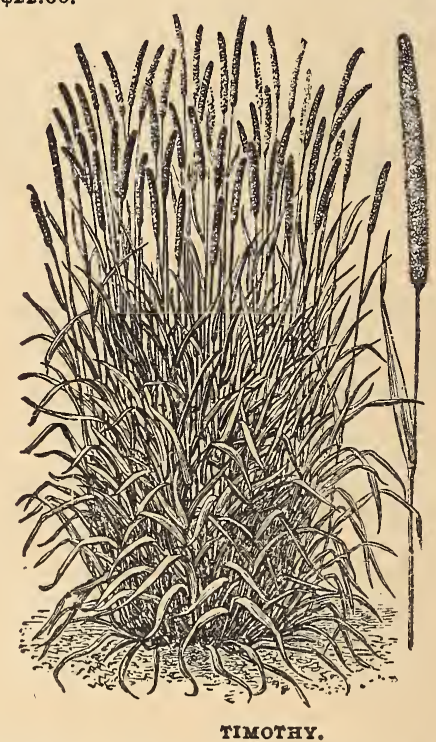

ALSIKE CLOVER. Sow 6 to 8 lbs. to an acre.Resembles in growth, duration, etc, the Medium Red Clover, except its flower is white and growth much finer; thrives better than Red Clover on poorer soil and will thrives better than Red Clover on poorer soil and will
not winter out as much as the other kinds of Clover. 30c. per $1 \mathrm{~b}$.; I5 lb. lots, $\$ 3.75$; 100 $1 \mathrm{~b}$. lots, $\$ 24.00$.

CRIMSON CLOVER. Sow 10 to $12 \mathrm{lbs}$, to an acre. -A most valuable sort for soiling. It grows from threc to four feet high. Sow in July and August for soiling or mowing the ensuing Spring. 20c. per lb.; I5 lb. lots, $\$ 1.75 ; 100$ lb. lots, \$12.50.

PEA VINE, OR MAMMOTH RFD CLOYFR. SO 20 to 25 lbs. to an acre. Resembles the Medium Red Clover, but grows coarse and stocky; very valuable for plowing under. $35 \mathrm{c}$. per lb.; is lb. lots, $\$ 4.50 ; 100 \mathrm{lb}$. lots, $\$ 28.00$.

MEDIUM RED CLOVER. Sow 8 to 12 lbs. to an acre- - It is a perennial, but of very few years' duration Is considered the most nutritious of all the species, and most valuable for cattle feeding and soil improver. $35 \mathrm{c}$. per $1 \mathrm{~b}$.; $15 \mathrm{lb}$. lots, $\$ 4.25$; $100 \mathrm{lb}$. lots, $\$ 27.50$.

WHITE CLOVER. Sow 6 to $8 \mathrm{lbs}$. to an acre-Valuable for lawn and pasture. $65 \mathrm{c}$. per $1 \mathrm{~b}$.; $15 \mathrm{lb}$. lots, $\$ 8.25$.

RAPE DWARF ESSEX. Sow 10 to $12 \mathrm{lbs}$. to an acre -Does well to sow with Oats, Southern Cow Peas and Sweet Fodder Corn. If well grown it is the best and cheapest pasture for hogs. By itself it is excellent green food for poultry. Good green food for poultry. sheep and hogs. I5 c. per 1b.; 15 lb. lots, \$1.80. 
SWEET CLOVER (Melilotus Alba). Sow 15 to 20 lbs. to an acre of hulled seed.- Very valuable for soiling, very excellent for sowing in early Spring on land to be sown later to Alfalfa. Grows from 3 to 5 feet high and can be cut two or three times if wanted for forage. I $5 \mathrm{c}$. per lb.; i $5 \mathrm{lb}$. lots, $\$ 2.00$.

\section{RIBSAM'S PERMANENT GRASS MIXTURE FOR HAY AND PASTURE MEADOWS AND UPLANDS.}

Sow 50 to 60 lbs. to an acre.

This is the most profitable crop that a farmer can put in his soil. Seeding should be done in July and August. You seldom miss a catch. The following season it will cut two to three tons, on an average, to an acre, which it has proven to itself. The quality is far superior to clover and timothy hay. It will also do fairly well sown in oats during April. 35c. per lb.; $5 \mathrm{lb}$. lots and over, 30c. per $1 \mathrm{~b}$. 25 lbs. to the bushel.

\section{WINTER RYE.}

A valuable catch-crop, when Fall-sown Rye and Wheat is Winter-killed. 5c. per lb.; i $5 \mathrm{lb}$. lots and over, 4c. per $1 \mathrm{~b}$.

\section{PEAS AND BEANS FOR FODDER AND SOILING.}

Sow 60 to $75 \mathrm{lbs}$. to an acre.

CANADA WHITE.-Sow with Oats. Side Oats is preferred, being a stronger grower and heavier in grain. No Green Forage is so profitable to Milch Cows as this feeding. Ioc. per lb.; i $5 \mathrm{lb}$. lots and over, 8c. per lb.

COW PEAS, BLACK.-Best variety as a soil enricher. Also for hay and pasture for cattle and hogs. It is the cheapest method to make poor land rich. Ioc. per lb.; I $5 \mathrm{lb}$. lots and over, 8c. per $1 \mathrm{~b}$.

SOJO BEANS, MAMMOTH. - Yellow seed. Do equally well on both light and medium heavy soils. The use of this crop is increasing very rapidly in all sections and is proving to be one of the most valuable and important forage and feed crops for the farmer. soc. per lb.; $15 \mathrm{lb}$. lots and over, 6c. per lb.

WILSON SOJO.-Black seed. Very early, good grower. Height, about 3 reet. Best sort of Sojo to grow in New Jersey. I $2 \mathrm{c}$. per lb.; i $5 \mathrm{lb}$. lots and over, $7 \mathrm{c}$. per $1 \mathrm{~b}$.

\section{OATS.}

32 lbs. to the bushel.

STORM KING.-A Side Oat, grain and straw again as large as the common Sprangel Oat and a very heavy yielder. 7c. per lb.; I $5 \mathrm{lb}$. lots and over, 4c. per $1 \mathrm{~b}$.

TARTER.-Large grain, large straw and a large cropper. A side oat. The only oat to grow with Canada field pea for green fodder for cattle feeding. 7c. per field pea for green fodder for catt
$1 \mathrm{~b}$; $15 \mathrm{lb}$. lots and over, $4 \mathrm{c}$. per $1 \mathrm{~b}$.

\section{WINTER WHEAT.}

60 lbs. to the bushel.

DEITZ LONGBERRY.-Has a very large hard berry. Bearded. One of the best red wheats. 7c. per lb.; I5
lb. lots and over, $4 \mathrm{c}$. per lb.

FULTZ, BALD.-A first class milling wheat. 7c. pe lb.; is lb. lots and over, 4c. per lb.

\section{MISCELLANEOUS FARM SEEDS.}

(Prices are subject to market variations.)

\section{Vetches.}

SPRING VETCH (Vicia Sativa). Sow 40 to $50 \mathrm{lbs}$ to an acre. -Highly valuable for soiling or for green manuring. Sometimes grown with oats for forage. Makes excellent cutting in June for cattle. Ioc. per lb. I $5 \mathrm{lb}$. lots and over, 8c. per lb.

HAIRY, or WINTER VETCH (Vicia Villosa). So 40 to $50 \mathrm{lbs}$. to an acre.-It is noted for its hardiness and is highly valuable as a winter cover crop. It is used for forage and fertilizing purposes, will live over winter in well-drained soils. It is a perennial, but drops its sced freely and will come up year after year if sown in September. Will make excellent forage for following spring. Will yield $\mathrm{I}^{1 / 2}$ to 4 tons per acre. $20 \mathrm{c}$. per $1 \mathrm{~b}$; $15 \mathrm{lb}$. lots and over, I $5 \mathrm{c}$. per $1 \mathrm{~b}$.

BROOM CORN EVERGREEN.-Carefully saved from selected brush. 20c. per $1 \mathrm{~b}$.; $15 \mathrm{lb}$. lots and over, $15 \mathrm{C}$ per $1 \mathrm{~b}$.

AMBER SUGAR CANE, or SORGHUM-Great fod der producer and very nutritious for cattle and stock feeding; it can be cut down several times in a season Very profitable for a dairy farm and hog raising. I5C per $1 \mathrm{~b}$.; i $5 \mathrm{lb}$. lots and over. Ioc. per $1 \mathrm{~b}$.

FLAX SEED (Linum Usitatissimum).-Extra cleaned. 2oc. per $1 \mathrm{~b}$.; i $5 \mathrm{lb}$. lots and over, I5c. per $1 \mathrm{~b}$.

SUNFLOWER (Helianthus Annus).-15c. per 1b.; 25 lbs. or more, Ioc. per lb.

\section{BIRD SEEDS.}

Prices Variable:

If by mail, postage must be added at the Parcel Post rate.

CANARY, BEST SICILY (Phataris Canariensis).I 5 c. per lb.; is lb. lots and over, roc. per $1 \mathrm{~b}$.

HEMP (Cannabis Sativa).-I5c. per 1b.; I5 1b. lots and over, roc. per $1 \mathrm{~b}$.

MAW (Papaver Rhoeos).-25c. per lb.

MILLET (Panicum Milaceum).-- roc. per 1b.; $15 \mathrm{lb}$ lots and over, $8 \mathrm{c}$. per $1 \mathrm{~b}$.

RAPE (Brassir Napus).-I5c. per lb.; I 5 lb. lots and over, I 2c. per lb.

MIXED BIRD SEED.-I5c. per 1b.; I5 lb. lots and over loc. per $1 \mathrm{~b}$.

MOCKINGBIRD FOOD.-5oc. per 1b. bottle.

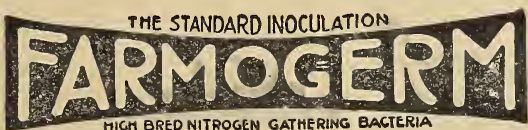

\section{PRICES REDUCED}

\section{A Seed Inoculation that Increases Crop Production.}

New methods of production have given lower prices. You cannot now afford to do without FARMOGERM.

A special composite culture is prepared for peas, beans, and sweet peas, $1 / 4$-acre size only. You'll get more peas and beans, and larger sweet peas by using this, Ask for No. 5. Price, 50 cents.

Farmogerm prices are: I-acre size, \$I; 3-acre size, \$2.50; I2-acre size, \$9. Full directions accompany each bottle. 


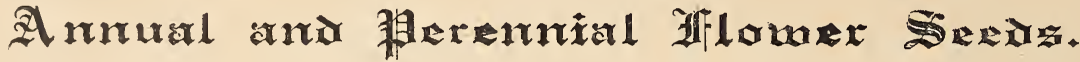

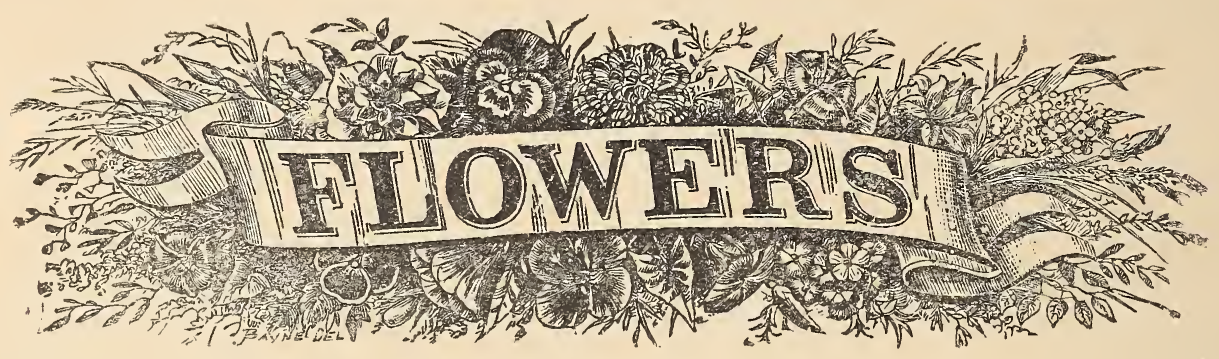

Blooming the First Year From Seeds.

UPON THIS CLASS OF PLANTS THE GARDEN IS DEPENDENT FOR MANY OF TH RICHEST, MOST SHOWY, AND BEAUTIFUL FLOWERS, AND, CONSE.

QUENTLY, WE HAVE TAKEN SPECIAL CARE IN THE COILEC

TION AND SELECTION OF THE CHOICEST SEEIS

ABRONIA UMBELLATA.-Trailing plants with rosylilac flowers in clusters. Ioc. per pkt.

ABOBRA.-roc. per pkt.

ABUTEILON MIXED (Flowering Maple).-Rapid growing plant, bearing a profusion of bell-shaped flowers. I oc. per pkt.

ACACIA.- Half hardy shrub, having beautiful racemes of yellow globular flowers. I oc. per pkt.

ACANTHUS (Bear's Broech).--Rosy white flowers, blooming in August and September. 5c. per pkt.

ACONTIUM (Monks Hood or Wolfsbane).-Produce long spikes of curious blue and white flowers. Ioc. pkt.

ADONIS AUTUMNALIS.-Annual, crimson; i ft. $5 \mathrm{c}$. per pkt.

ADIUMIA CIRRHOSA (Mountain Fringe, Allegheny Vine).-Bi-annual climber, with tube-shaped flesh. colored flowers like bleeding heart. Ioc. per pkt.

AGERATUM (Floss Flower). BLUE PERFECTION.Annual, dark blue. roc. per pkt.

ALBUN NANUM.-Pure white, 8 in., roc. per plt.

ALYSSUM (Mad Wort). CARPET OF SNOW-Dwarf, pure white. 5c. per pitt.

MARITUM.-Of trailing habit, pure white. 5c. per pit.

AMARANTHUS.-Mixed colors, annual, bright red and variegated drooping flower spikes. 5c. per pkt.

BICOLOR RUBRIE.-roc. per pkt.

AMPELOPSIS VETCHII (Boston or Japanese Ivy).A hardy climber with olive green leaves. I oc. per

ANEMUNE (Wind Flower).-Mixed colors, very fine for

bouquets. $5 \mathrm{c}$. per pkt. low golden blossom all summer. Ioc. per plat.

ANTIRRHINUM (Snapdragon).--One of the best cut flowers that can be grown in the garden, they prefer a sunny position.

A.NTIRRHINUM-Mixed. 5c. per pkt.

$\begin{array}{ll}\text { " } & \\ \text { " } & \text { Yellow. Ioc. per pkt. } \\ \text { White. Ioc. per pkt. } \\ \text { “ } & \text { Crimson. Ioc. per pkt. } \\ \text { Rose. roc. per pkt. } & \text { Pink, roc. per pkt. }\end{array}$

AQUILIGIA (Columbine).-Mixed exquisite flowers with flowers on long spurs. IOc. per pkt.

ARISTALOCHIA SYPHO (Dutchman's Pipe).-Heavy foliage, making dense shade. Flowers yellow and brown. Ioc. per pkt.

ARMERIA (S'ea Pink).-Very pretty edging plant bearing rosy-pink flowers. I $5 \mathrm{C}$. per pkt.
ASPARAGUS PLUMOSUS NANUS.-Fresh greenlouse seed. Ioc. per pkt.

SPRINGURI.-Fresh greenhouse seed. Iøc. per pkt.

ASTERS, CHINA.-Mixed, a very superb collection. 5c. per pkt.

BRANCHING WHITE.-Extra fine pure white, blooming profusely. Ioc. per pkt.

VICTORIA BLUE.-A popular blue. roc. pkt. QUEEN OF THE MARKET, CRIMSON.One of the best reds. roc. per pkt.

GIANT COMET ROSE.-Flowers of good size. Ioc. per pkt.

QUEEN OF THE MARKET, LAVENDER.Ioc. per pkt. Many other varieties of Asters. QUEEN OF THE MARKET, T,AVENDER.-

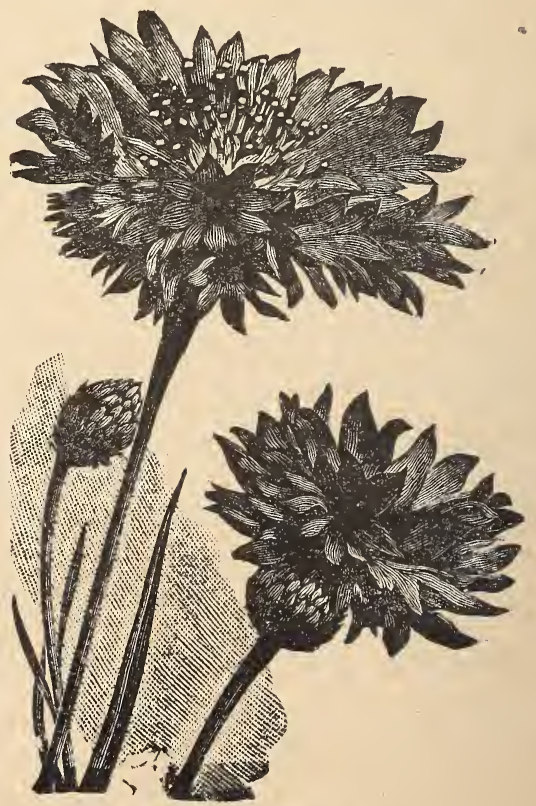

CENTAURIA, RAGGED ROBIN. 
BALSAM (Lady Slipper).-An old favorite, producing a profusion of brilliant-colored double flowers. 5c. per profusi

BALLOON VINE (Love in Puff).-Climber flowers, white seed, like small balloon. 5c. per pkt.

BACHELOR' $\subseteq$ BUTTON (See GOMPHRENA)

BEGONIAS (Tuberus Rooted).- Single in separate colors. Scarlet, crimson, rose, white, yellow and Double in separate colors. Scarlet, rose white, yellow. $25 \mathrm{c}$. each; $\$ 2.50$ per doz. Mixed. 2oc. each; $\$ 2.00$ per doz.

BELLIS (English Daisy).-Perennial, double mixed daisy, roc. per pkt. Daisy).-Large double pink.

BRACHYCOME (Swan River Daisy). - Free flowering dwarf-growing, suitable for edging, producing blue and white flowers. $5 \mathrm{c}$. per pkt.

BROMUS. - 5c. per pkt.

BROWALLIA ELATA (Amethyst).-Large sky-blue flowers with white centre. $5 \mathrm{c}$. per pkt.

BROWALLIA ALBA. - Large white flower. 5c. per pkt.

CALANDULA (Pot Marigold) - Has large, showy, orange flowers. It is easy to cultivate. $5 \mathrm{c}$. per pkt.

CACALIA (Tassel Flower).-A neat annual flower, golden yellow and scarlet, fine for borders. 5c. per pkt.

CALCEOLARIA. - Plants bear a mass of beautiful flowers of all colors. 5c. per pkt.

CANARY BIRD VINE.-Grows rapidly. I $5 \mathrm{c}$. per pkt.

CANDYTUFT (Iberis). - Universally known, one of the best flowering plants for cutting.

CANDYTUFT (Iberis).--Mixed colors. 5c. per pkt.

CANDYTUF'T (Iberis).-White and other solid colors. $5 \mathrm{c}$ per pkt.

CANNA (INDIAN SHOT).-Mixed colors. Ioc. per pkt. CAMPANULA (CANTERBURY BELLS).-Beautiful large flowers, bell shaped and blooming quite pro-

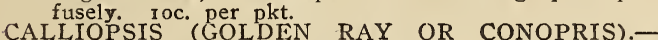
Dwarf compact plants, covered with flowers of rich maroon edged with golden yellow; good cut flowers. fe. per pkt.

CARNATIONS (Mixed)-Very fine for cut flowers. I5c. per pkt.

CARL,NAL CLIMBER.-Has fine foliage, grows rapidly, bears red trumpet flowers. Ioc. per pkt.

CHERIANTHUS (See Wall Flower).

CHRYSANTHEMUM.-Mixed colors producing flowers of many colors. $5 \mathrm{c}$. per pkt.

CELOSIA (COCKSCOMB).-Mixed colors. 5c. per pkt. RED EMPRESS. - Rich crimson combs of colos. sal proportions. 5c. per pkt.

CLEOME (GIANT SPIDER FLOWERS)-Plant at tains height of three and one-half feet, each branch having a large head of rosy-crimson flowers. Iоc. per pkt.

CENTAUTRTA (DUSTY MILLER) GYMNOCARPA.White foliage, fine for hanging baskets, borders and posts. It has silvery white leaves, which are broadly cut 5 . per nkt

CENTAURIA CYANUS (Blue core flower).-5c. per nkt

CENTAURIA IMPERIALIS (Royal Sweet Sultans).Sweet button. I oc. per pkt.

CEN. CANDISSIMA.- I oc. per pkt.

CINERARIA.-Fine mixture of the dwarf variety, fine starry flowers of all variegations and colors. 5c. per pkt.

CINERARIA STELLATA.-25c. per pkt.

$$
\text { “ HYBRIDA.-25c. per pkt. }
$$

CANDISSIMA. - 5 c. per pkt.

CALEUS (FLAME NETTLE). -This is a selected mixture of fine, highly colored hybrid varieties. Ioc. per pkt.
CONVOLVULUS MINOR (MORNING GLORY).-This is the dwarf Morning Glory which bears a profuse abundance of large richly-colored flowers. 5c. per plt. TAPANESE (See IPOMCEA).-1OC. per pkt.

COCCINEA INDICA (SCARLET-FRUITED IVY. LEAVED CLIMBER).-A handsome climber of the gourd species, with fine snow-white bell-shaped flow. ers and brilliant carmine fruit. Ioc. per pkg.

COBEA SCANDENS (CUPS AND SAUCERS VINE) -A rapid climber to $50 \mathrm{ft}$., large bell-shaped purple flowers. 5c. per pkt.

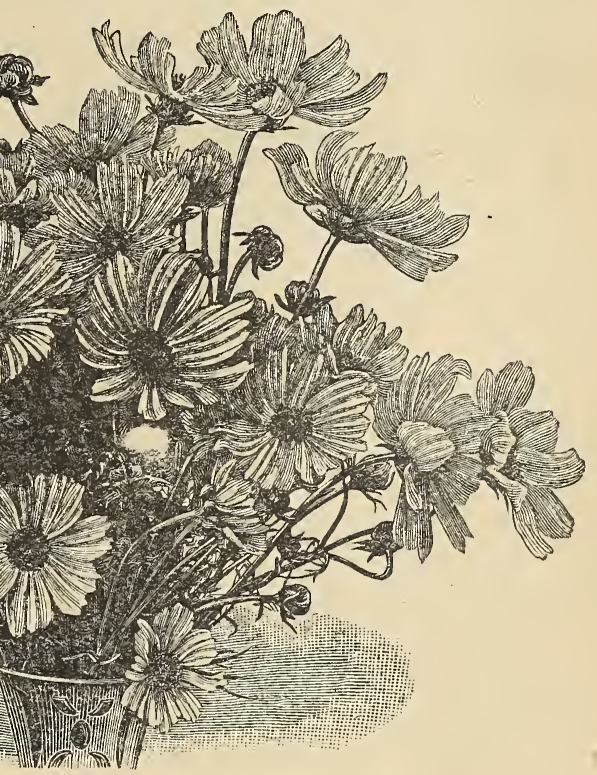

cosMOS.

CORNFLOWER (CENTAURIA) CYANUS-This very valuable as a cut-flower in the old-faghioned garden. 5c. per pkt.

CONVOLVULUS MAJOR (MORNING GLORY).-Thi is the climber and is one of the most free growing and blooming plants under cultivation. 5c. per plet.

COSMOS.-These are the most popular of all fall-bloom ing plants, producing thousands of flowers of all colors.

FINE MIXED. 5c. per plst.

RED. roc. per pkt.

PINK. zoc. per pit.

STRIPED, roc. per pkt.

WHITE, roc per pkt.

CUPHEA (CIGAR PLANT).-An old favorite for the summer garden, bearing innumerable vermillion tube shaped flowers. Ioc. per pkt.

CUCUMBER, WILD. 5 C. per pkt.

C_CUMIS. $5 \mathrm{c}$. per pkt. par pkt.

CYPRESS VINE (IPOMGEA QUAMOCLIT).-Thi vine grows rapidly, having a fern-like foliage and bears a mass of beautiful star-shaped flowers. $5 \mathrm{c}$. Der pkt.

CYPERUS (UMBRELLA PLANT).-This plant is very valuable as both $a$ house and an aquarium plant. 5c. per pkt.

DAHLIA (LITTLE PET DWARF).-Perennials, will bloom first year if sown early. Ioc. per plat.

DATURA (TRUMPET FLOWER).-An ornamental annual, with large showy flowers making hasdoome plants, 2 to $3 \mathrm{ft}$. high. $5 \mathrm{c}$. per plst.

DIANTPUS (CARNATION).-Double mixed, 25c. per plkt.

“

(MARGUERITE).-Summer pink, 12 to

15 in. high. roc. per pkt.

(JAPAN PINK).-Double mired color varying from rich velvety crimeon to most delicate rose. SC. per plt. 


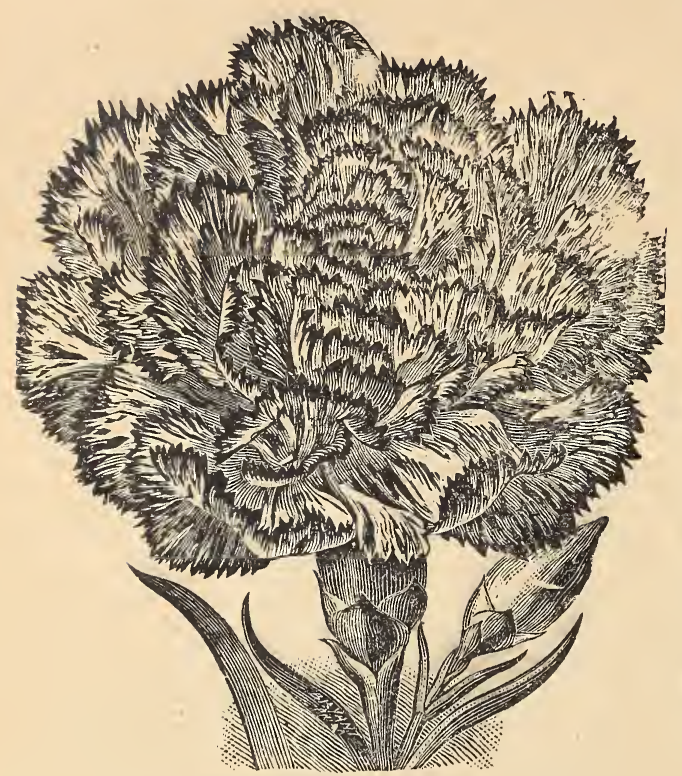

CARNATION, MARGUHRITE

DIGITALIS (FOX GLOVE).-Mixed colors, fowers produced on long stems, making a very beautiful plant in the garden. Ioc. per pkt.

DOLICHOS (HYACINTH BEAN)-Climber, grows ten feet, flowers freely in erect racemes and produces ornamental seed pods. Ioc. per pkt.

ERIANTHUS. - roc. per plit.

ECHENOCYSTIS' LOBATA (WILD CUCUMBER).a very rapid climber, producing sprays of white flowers during July and August. 5c. per pkt.

ESCHSCHOLTZIA (CALIFORNIA POPPY).-This is a very attractive plant for bedding, blooms until frost, flowers mixed in colors. $5 \mathrm{c}$. per pkt.

EUPHORBIA VARAGATE (SNOW ON THE MOUNTAIN.)-Attractive foliage striped with white. roc. per pkt.

FUSCHIA (LADY'S EARDROP).-A plant easily cultivated in the garden or in a shady place in the garden. 25c. per pkt.

GAILLARDIA SCARLET (BLANKET FLOWER).Has very showy flowers, blooming in great profusion. 5c. per pkt.

GAILIARDIA PICTA.-5c. per plt.

GERANIUM (PELARGONIUM).-We have a vers good mixture of the seed of this popular plant. 2oc. per pkt.

GERANIUMS (ASSORTED).-Ioc. per plt.

GOLDEN GLOW (RUDBECKA).-A very tall plant, suitable for hiding fences, and bearing large yellow flowers, very suitable for cut flowers. 5c. per plit.

GOMPHRENA (BACHELOR'S BUTTON).-This is a first-rate bedding plant; the flowers can be dried and used in winter bouquets. 5c. per pkt.

GYMERIASM (PAMPAS GRASS). - 5c. per pkt.

GODETIA.-Bushy annual, with large, showy flowers of rich coloring. 5c. per pkt.

GOUKD BALSAM APPLE (CUCURBITA).-A very pretty climber with glossy foliage and round appleshaped fruit. 5c. per pkt.

GYPSOPHILA (BABY'S BREATH).-It bears large panicles of misty white flowers which are very suitable for mixing with other flowers. 5c. per plt.

HELIOTROPE (CHERRY PIE).-A perennial known to everyone; having a most delightful perfume. We have it in mixed, white and other colors. roc. per ptet
HELICHRYSUM (STRAW, OR ETERNAL PLOWER). - These are the best flowers for drying, are also very pretty in the garden. 5c. per pkt.

GOURDS (CUCURBITA).-Annual climber to $20 \mathrm{ft}$. with ornamental foliage and peculiar fruit. ge. per pkt.

HELIANTHUS, HARDY SUNFLOWER. - Hardy grower, with large golden flowers in autumn. 5c. per pkt.

HIBISCUS (MARSHMALLOW).-It has a large-sized, beautifully colored flower, and is very suitable for mixed beds. 5c. per pkt.

HOLIYHOCK (ALTHEA)-This annual is unsurpassed for a background; it has beautiful, long spikes bearing large gorgeous flowers. We carry both mixed and assorted colors. 5c. per pkt.

HOL, YHOCK. - WHITE. roc. per pikt.

“ $\quad$ YELLOW. roc. per pist.

PINK. roc. per pkt.

HUMULUS JAPONICUS (JAPANESE HOP).-A beautiful, fast-growing climber, resembling the hop vine. Ioc. per pkt.

IPOMOPSIS ELEGANS.- roc. per pkt.

IPOMGE (MOONFLOWER). - White, bearing large gorgeous flowers, which open in the eve. ning and close with the coming of the morning. The plant is a very rapid climber. roc. per pkt.

“ (JAPANESE). - These are by far the handsomest morning glory, having magnificent large flowers with colorings beyond description. Ioc. per pkt.

ICE PLANT.-Ioc. per pkt.

KOCHIA FIRE BALL.- - oc. per pkt.

JACOBIA DWARF DOUBLE.-1oc. per ptt.

LARKSPUR (DELPHINIUM).-Double mixed; is the finest variety, with splendid spikes of beautiful double flowers. 5c. per pkt.

LARKSPUR NUDICULE.-1oc. per plt.

“ FORMOSIUM.-5c per pkt.

“ CARDINAL. - roc. per plt.

LARKSPUR DWARF ROCKET.-It is a doable dwarf, growing but 18 in. 5c. per pkt.

LARKSPUR.-Assorted colors, a fine collection. 5c. per pkt.

LANTANA.-A most desirable bedding plant, blooming abundantly and growing from 2 to $3 \mathrm{ft}$. $5 \mathrm{c}$. per pkt.

LOBELIA.-This plant is most desirable for bedding and for hanging baskets. Ioc. per pkt.

LINARIA CYMBALARIA (RENILWORTH IVY).Perennial trailing plant suitable for basket work. roc per pkt.

MARIGOLD (TOGETAS) AFRICAN.-An old favorite, having large orange and yellow flowers. 5c. per plkt. FRENCH - This strain is more dwarf and bears striped flowers. 5c. per pkt.

MARVEL OF PERU (MIRABILIS, OR FOUE $\mathrm{O}^{\prime} \mathrm{CLOCK}$ ). - This is a handsome, well-known old flower, which does well everywhere. 5c. per pkt.

MESEMBRYANTHEMUM (TE PLANT), - D trailing plant with singular icy foliage and white flowers. 5c. per pkt.

MIMULUS MOSCHATUS (MONKEY FLOWER)Showy, profuse bloomer; does well in moist places. Ioc. per pkt.

MIMULUS TIGRINUS.-1oc. per pkt.

MIMOSA SENSITIVA (Sensitive Plant).-Leaves close and drop when touched, flowers pinkish-white. $5 \mathrm{c}$. per pkt. 
MIGNONETTE (RESEDA) ODORATA.-No garden is complete without it, for its sweet fragrance is very pleasing. $5 \mathrm{c}$. per pkt.

A S S.O R T E D.-A very choice collection of the different varieties. 5c. per pkt.

s.

ALLEN'S DEFIANCE.-5c. per plt.

“ MATCHET.-roc. per pkt.

MARANDIA BARCLIANNA.-5c. per pkt.

MYOSOTIS (FORGET-ME-NOT).-One of the most admired spring plants, bearing the well-known little blue flower. roc. per pkt.

\section{NASTURTIUM.}

For ease of culture, duration of bloom, brilliancy of coloring and general excellence, nothing excels Nasturtiums. All they need is a moderately good soil in a well-drained, sunny position, and from within a few weeks from the time they are sown until hard frost comes, there is an endless profusion of their gorgeous blossoms. The varieties offered below are the best selected from many sorts.

\section{Tom Thumb, Dwarf or Bedding Varieties.}

MIXED COLORS. -5 c. per pkt.; 15c. per oz.; $40 \mathrm{c}$. per $1 / 4$ lb.; $\$ I .25$ per lb.

\section{Tall or Climbing Varieties.}

MIXED COLORS.-5c. per pkt.; I5c. per oz.; 40c. per $1 / 4$ lb.; $\$ 1.25$ per $1 \mathrm{~b}$.

NICOTIANA (TOBACCO, OR TOBASCO FLOWER).Pink and white tubular flowers, blooming continually, sweet scented. roc. per pkt.

NIGELLA DAMASCENA (LOVE-IN-A.MIST, OR DEVIL-IN.THE-BUSH).-Has finely cat foliage with peculiar flowers of corn-flower blue shade. 5c. per pkt.

PANSY (VIOLA) MIXED.-This flower is known to everyone, fine mixed. 5c. per plst.

" "GERMAN.-Fancy colors, fine mixed. roc. per pkt.

". FRENCH.-Mammoth flowers. Ioc. per plst.

" " ENGLISH.-Large flowered. soc. per pkt.

PASSIFLORA (PASSION VINE),- Flowers violet and blue. roc. per plt.

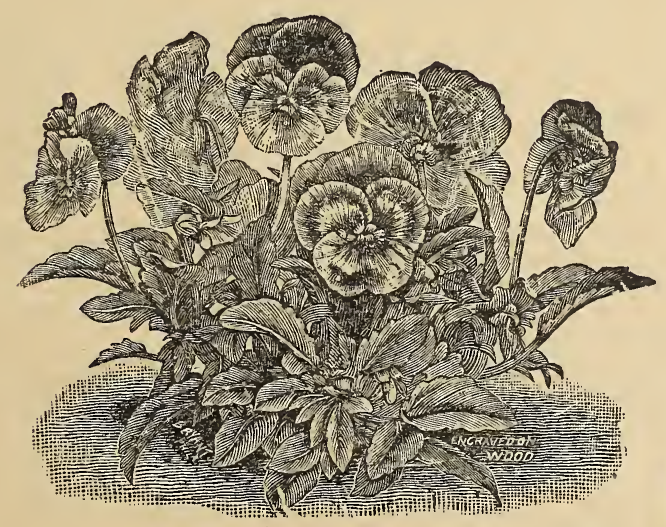

PANSY.
PENTSTEMNON (BEARD TONGUE).-A very hardy border plant, ranking with the best of bedding plants. roc. per pkt.

PETUNIA.-Few plants surpass this as both an outdoor and indoor decorative plant. We carry it in mixed and assorted colors both in single and double flowert. 5c. per pkt.

PHLOX DRUMMONDII.-This popular plant will grow in any soil, provided it is given sun. We carry it in assorted and mixed colors. 5c. per pkt.

PHLOX HARDY.-We carry this in four separate colore roc. per pkt.

POPPY (PAPAVER) ICELAND.-These are very suitable for cutting, bloom frat sear son, should be picked when in bud, foliage fern-like. 5c. per pkt.

"

SINGLE MIXED.-This is : mixture of fine single flowering sorts of all colors and variegs. tions. 5c. per pkt.

"

DOUBLE MIXED. - Same a above with exception that flow. ers are double. 5c. per plat.

SHIRLEY.-This is the beat of all single poppies, making magnificent profusion of color in the garden. 5c. per plt.

PORTULACA (SUN PLANT).-A beautiful plant for massing in beds or in rock work, producing a riot of color. 5c. per pkt. We have the seed of both the double and single-flowering varieties. yoc. per plit.

PRIMULA VERIS (COWSLIP).-These are one of the best spring flowering plants; they will stand the winter with a slight protection. roc. per plkt.

PRIMULA ARACUILA-2oc. per pkt.

RAGGED ROBIN (CENTAUREA).-This flower, known to every flower lover, comes in blue, rose and white. 5c. per pkt.

REHMANNIA ANGULATA.-Herbaceous perennial with tufted leaves and spikes of rose-colored flowers. $3 \mathrm{gC}$ per plkt.

RICINUS (CASTOR OIL BEAN).-Fine for centre of bed or massing; it is of stately growth, bearing beau. tiful fruit and foliage. 5c. per pkt.

RUDBECKIA (GOLDEN GLOW).-5c. per pkt.

SCABIOSA (MORNING BRIDE, OR EGYPTIAN ROSE).-An excellent cut.flower, therefore no gar. den is complete without it; can be had in dwarf or tall varieties and all colors. 5c. per pkt.

SCHIZANTHUS (BUTTERFLY, OR FR ING FLOWER). - It is a very airy and dainty flower, which are orchid-like and almost obscure the foliage so densely are they borne. roc. per plat.

SHASTA DAISY.-This is a special selection of hybrid daisies, bearing a flower of large size, which make it desirable for cutting. 5c. per pkt.

SILENE (CATCHFLY).-Bears white, pink and red flowers, making a very pretty and handsome plant. 5c. per pkt.

SMILAX-A desirable green foliage climber with a small white flower. It does best in pots in the house where it can be used for draping or festooning. 5c. per plst.

STATIS (SEAR LAVENDER).-Very good for bordering, producing panicles of minute flowers: it can be dried and used for winter bouquets. 5e. per plt.

STEVIA.-Bears a multitude of pure white flowers, which are very fragrant. $5 \mathrm{c}$. per pkt.

SUNFLOWER.-(HELIANTHUS).-This is a mixture of the miniature sunflower, containing a variety of smaller, larger, and curiously twisted petals varyine from the original miniature sunflower. 3C. Des ple. 


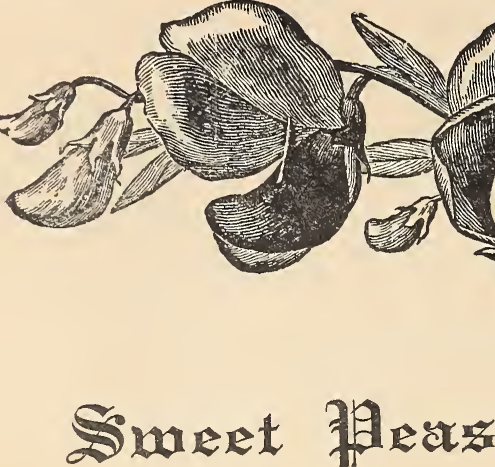

\section{THE GIANT.WAVED "SPENCER"}

The Spencers are the largest and most beautiful of all Sweet Peas, surpassing the older kinds in strong growth, size and form of flowers and continued profusion of bloom. buff.

MARGARET ATLEE SPENCER.-Wings pink-shaded

ASTA OHN SPENCER.-Soft lavender and purplishmauve.

PRIMROSE SPENCER.-Primrose.

DAINTY SPENCER.-Soft pink.

TRUE COUNTESS SPENCER.-Bright, clear pink.

KING EDWARD SPENCER.--Rich, bright crimson, very large waved flowers.

IVHITE SPENCER.-Pure White.

GEORGE HERBERT SPENCER.-Crimson.

Mixed Colors, 20c. per oz.; 6oc. per $1 / 4$ lb.; $\$ 2.00$ per $1 \mathrm{~b}$.

Named varieties, Spencer, 25c. per oz.; 85c. per $1 / 4$ $1 \mathrm{~b}, ; \$ 3.00$ per $1 \mathrm{~b}$

\section{Grandiflora Strain.}

KING EDWARD VII.-Bright scarlet.

NORA.-White.

HON. MRS. E. KENYAN.-Salmon orange.

LADY GRISWOLD HAMILTON.-Lavender.

AURORA.-Rose and orange on white.

PRIMA DORMA.-Vermilion rose.

PHENOMENAL.-White shaded lilac.

PRINCE OF WALES.-Rich carmine rose.

PRIMA DONNA.-Rosy pink.

BLANCHE FERRY.-Bright pink white wings.

NAVY BLUE.-Deep indigo blue.

COUNTESS OF CADOGAN.-Dark purple.

DOROTHY ECKFORD.-Large pure white.

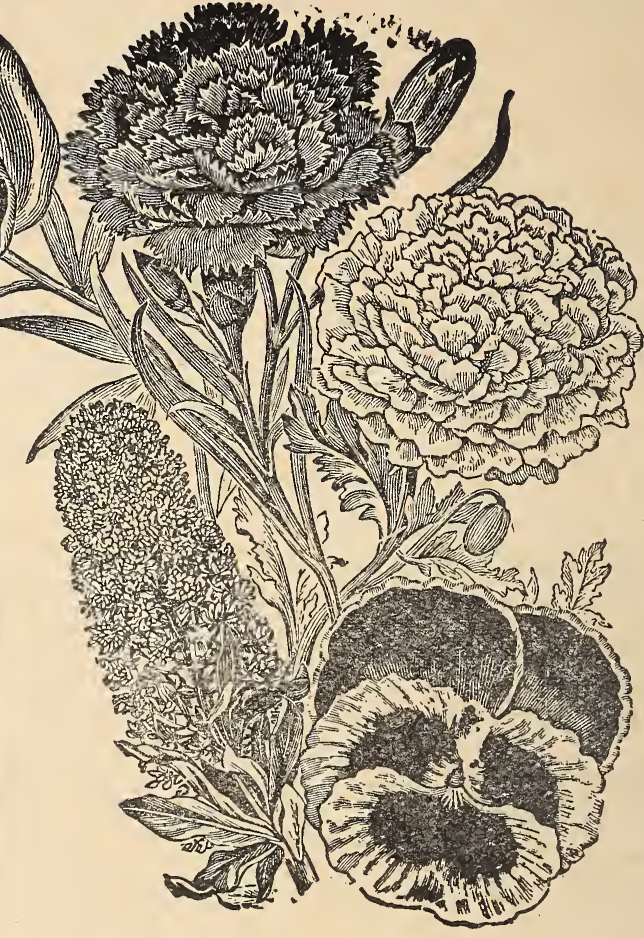

Named varieties, Ioc. per pkt.; I 5 c. per oz.; 5॰c. per $1 / 4$ 1b.; $\$ 1.50$ per $1 \mathrm{~b}$.

Mixed colors, 5c. per pkt.; Ioc. per oz,; $25 \mathrm{c}$. per $1 / 4 \mathrm{lb}$; \$I.OO per $1 b$.

SWEET WILLIAM (DIANTHUS BARBATUS).This is another of the great favorites of the garden being beautiful and well adapted for cutting. We have it in all the separate colors and in mixed packages. sc. per pkt.

TEN-WEEKS-STOCK (GILLIFLOWER). - The atock is a very popular annual because of its variety of color and its adaptation as a bedding and pot plant We carry a full line of the seed in the separate and mixed colors. 5c. per plst.

TRITOMA (Red Hot Poker).- - 5 c. per pkt.

THUMBERGIA (BLACK.EYED SUSAN).-A beautiful, rapid growing climber; does well in hanging baskets, prefers a warm, sunny place. 5c. per plkt.

VINCA (MADAGASCAR PERIWINKLE).-This is a very satisfactory bedding plant; also suitable for cutting. We have it in separate and mixed colors. Sc. per pkt.

VERBENA.-Known to everyone; it is a free bloomer of vigorous habits, bearing large, gorgeously colored flowers. 5c. per pkt.

VALERIANA (GOLDEN HELIOTROPE).-A fine old. fashioned hardy plant, with heads of old rose, with a strong heliotrope odor. 5c. per pkt.

VIOLET SWEET.-Large flowered single varieties, in blue and white. 5c. per pkt.

WALL FLOWER.-It is an early spring bloomer, bearing beautiful flowers. $5 \mathrm{c}$. per pkt.

XERABTHEMUM (EVERLASTING FLOWER).-This is -the prettiest of all everlasting flowers. The seed is mixed and contains all the colors. 5c. per plt.

ZINNIA (YOUTH AND OLD AGE).-The lowers are very brilliant and showy, they are pretty and are a favorite. 5e. per pkt. 


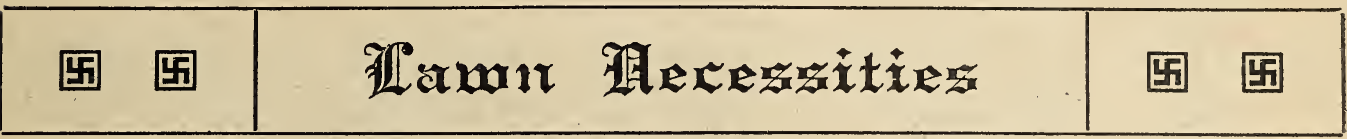

\section{Lawn Mowers}

(All Prices Subject to Change with Market Conditions.)

We carry the largest and finest assortment of lawn mowers in the city. Do not fail to see our line before selecting a mower for your lawn.

\section{Pennsylvania.}

The Pennsylvania high-wheel, compound-gear lawn mower is universally recognized as the standard by which all other mowers are measured. It will last longer, cut easier and do more work than any other mower on the market. Price, 15 in., $\$ 25.50$; 17 in., $\$ 29.50 ; 19$ in., $\$ 32.00 ; 21$ in., $\$ 35.00$.

\section{The Coldwell LIne.}

The Coldwell line of mowers has been on the market for the last fifty years. This company permits nothing but the best material and workmanship to enter into its mowers. We will warrant any mower from this line to give satisfaction.

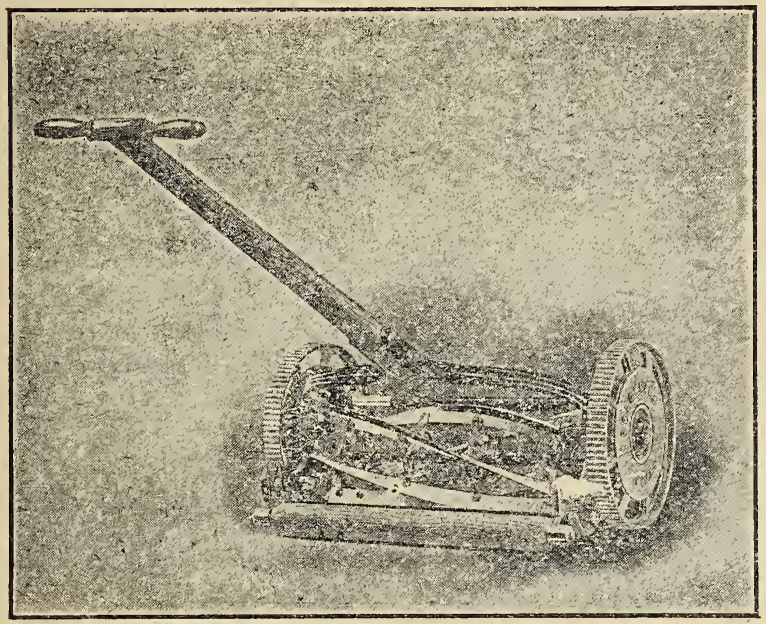

COLDWELI, IMPERIAL MOWËR.

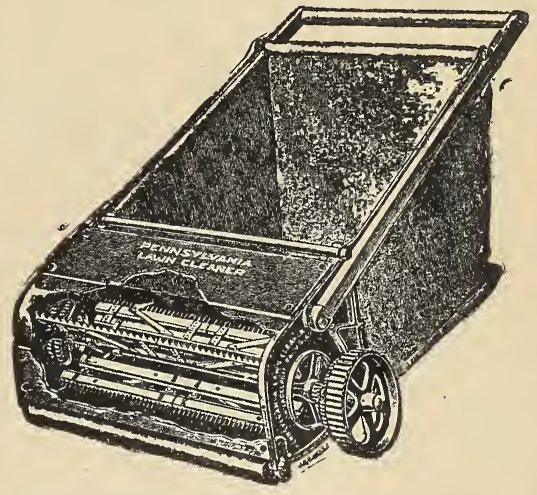

PenNSyluania Lawn Cleaner and Rake.

\section{Lawn Cleaner and Rake.}

This machine will remove from your lawn not only cut grass but all sorts of litter, leaves and trash. It is one of the best articles to rid your lawn of wire-grass. With it one man can do as much as four men with rakes. Price, on application.

\section{"Colonlal."}

It meets the demand for a ball-bearing machine within the reach of all. The workmanship on this machine is fine. Wheels 8 in. Price, $\$ 9.25,12$ in.; $\$ 9.75,14$ in.; $\$ 10.25$, 16 in.; $\$ 13.00,18$ in.

\section{"Cadet."}

It is a low-priced mower with full money value. This mower we will guarantee to do good service at a cost of little above the poor mowers so freely put out. Price, $\$ 6.75$, 12 in.; $\$ 7.35 ; 14$ in.; $\$ 7.75$, 16 in.

\section{Philadelphia Graham.}

It is a very high grade, all steel mower, with no front rod and 10 -inch wheel, and a train of gears on both sides. It is one of the highest achievements in the manufacture of lawn mowers. Price on application.

\section{"Imperlal."}

It is made of the best material obtainable, and is equipped with all the latest devices such as the patent reversible channel-shaped bottom knife, etc. This mower has a $10 \% / 4$ " wheel and is a pleasure giver when in use. Price, $\$ 15.00$, 14 in.; $\$ 16.00,16$ in.; $\$ 17.00,18$ in.

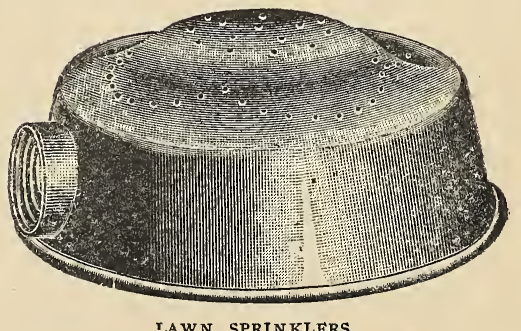

IAWN SPRINKLERS. 


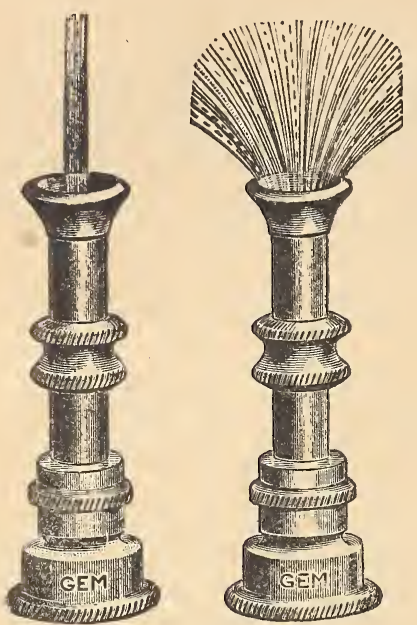

GEM NozzLE.

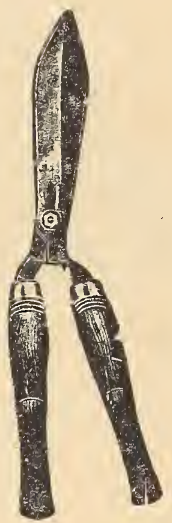

ENGLISH IIEDGE SHHARS.

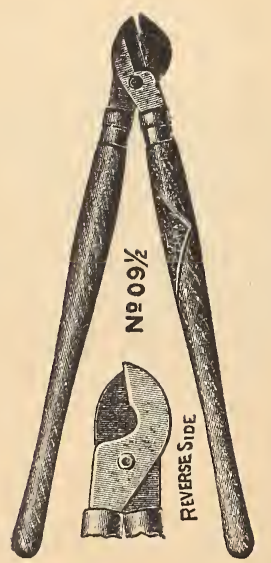

LOPPING SHEARS.

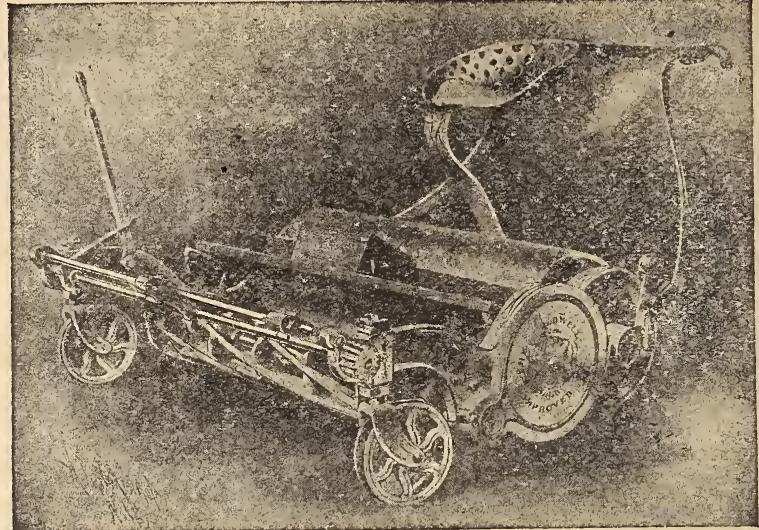

\section{COLDWELL IMPROVED HorsE MOWER.}

"COLDWELL PARK."

It is the best ball-bearing lawn mower on the market because the ball-bearings are in the drive wheels thus carry. ing the weight of the machine and lightening the draft. The mower carries five knives with the simplest adjustment made and $101 / 4$ in. wheels. Price, 14 in., $\$ 18.00 ; 16$ in., $\$ 20.00 ; 18$ in., $\$ 22.00 ; 20$ in., $\$ 24.00$.

\section{"Lakewood."}

It is a medium-priced ball-bearing mower. It is a best seller and has many good features. Price, $\$ 11.00$ for 14 in.; $\$ 12.00$ for 16 in.; $\$ 13.00$ for 18 in.

\section{Coldwell's Improved Horse Lawn Mower.}

It is acknowledged to be the best horse mower on the market. It is acknowledged as the standard of quality, being in many parks and golf links. This mower is complete with seat, shaft and side draft attachment, and can be had with either four or six blades in the revolving cutter. Price on application.

\section{Coldwell' Lawn Trimmer.}

It is made to meet the demand for a machine to get close to buildings, etc., and cut the grass.

\section{Speclal Mowers for Putting Gresns, Etc.}

When in the market for a putting green mower or motor lawn mower, or any special design of machine, come to Ribsam's, for we either have it or will get it for you. Prices on application.

\section{Hose Nozzles.}

GEM.

These are the best, all around nozzles on the market. They can be used as sprinklers on the lawn, in the gardem or in the street. By simply turning, it changes from a fine spray to a stream. Price, 6oc. to $\$ 1.00$.

\section{Lawn 8prinklers.}

A lawn sprinkler is an absolute necessity. We have 2 liberal supply and assortment from which you can sefect.

THE FOUNTAIN,

BARY FOUNTAIN,

HERO.

VICTOR,

ENTER PRISF

RAINMAKFR

Prices, 50c. to $\$ \mathbf{5} .00$. 


\section{Roller Bearing Lawn Rollers.}

Winter thawing and freezing heaves the ground and loosens the roots of the grass, the roller packs it back and preserves. Constant rolling eradicates moles. In offering you this roller-bearing lawn roller we do so with the utmost confidence in it for easy draft, light weight and durability.

\section{Diameter \\ Inches.}

Length. Sect.

19, $\ldots \ldots \ldots \ldots \ldots \ldots \ldots \ldots \ldots \ldots$.

r $5, \ldots \ldots \ldots \ldots \ldots \ldots \ldots \ldots \ldots, 22$

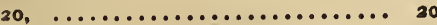

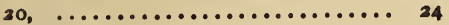

so, $\ldots \ldots \ldots \ldots \ldots \ldots \ldots \ldots \ldots \ldots, 30$

$24, \ldots \ldots \ldots \ldots \ldots \ldots \ldots \ldots \ldots, 30$

24

Price, $\$ 10.00$ to $\$ 22.00$.

We also have the Water Ballast Lawn Roller. With this roller you can vary your weight as desired, all the way from 90 lbs. to 800 lbs. Prices are variable and will be given upon application.

\section{Hose Reels.}

A garden which requires fifty foot of hose also requires one of our all-iron hose reels. They are light, durable and frictionless and will not tip over.

No. 10, 21-inch wheel, holds $100 \mathrm{ft} . \mathrm{K}^{\prime \prime}$ hose.

No. 20, 24-inch wheel, holds $200 \mathrm{ft}$. $\$ / 4^{\prime \prime}$ hose.

No. 30, 30-inch wheel, holds $500 \mathrm{ft}$. $3 / 4^{\circ /}$ hose.

Iron, $\$ 3.50$ and up; Wood, $\$$ r.5u and up.

\section{Cooper Hose Mender.}

This mender is made of copper with barbs in it. The hose will never slip or leak. It makes an absolutely tight connection. Price roc. each; $\$ 1.00$ doz.

\section{OImstead Mole Trap.}

This mole trap is absolutely the best trap on the market. The mole cannot get away from it, other animals cannot get into it. It is the superior trap for the hot bed or lawn. Price $\$ 2.00$. Others at $\$ \mathbf{1} .35$.

\section{The Capltol Lawn Trimmer and Edger.}

This machine fills a long-felt want. It cuts the grass close to buildings, etc., and squares the edges along the walk. It is no backbreaker and is a necessity for your lawn or garden Price. $\$ 8.50$

\section{L.awn and Border Shears.}

These shears are of the best English make, having long handle with two or one wheel to rest them upon while in operation. Price. $\$ 2.75$ to $\$ 4.50$.

PRUNING SHEARS, 50c. to $\$ 4.00$.

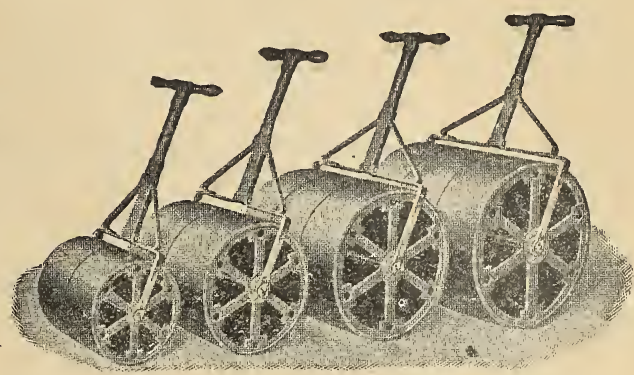

ROLLER BEARING LAWN ROLLERS.

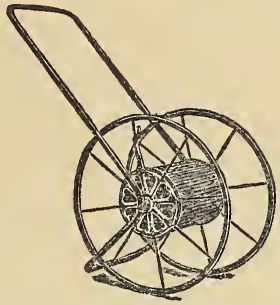

HOSE REEL.

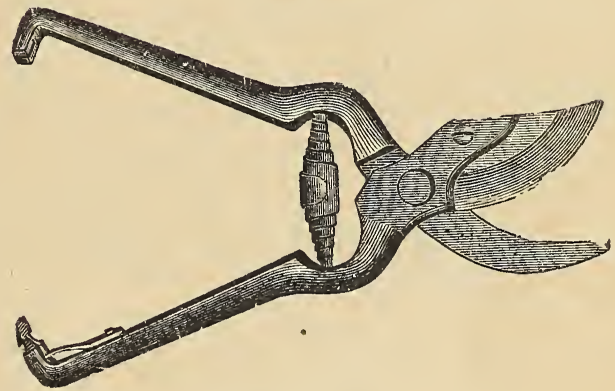

Hand Pruning.

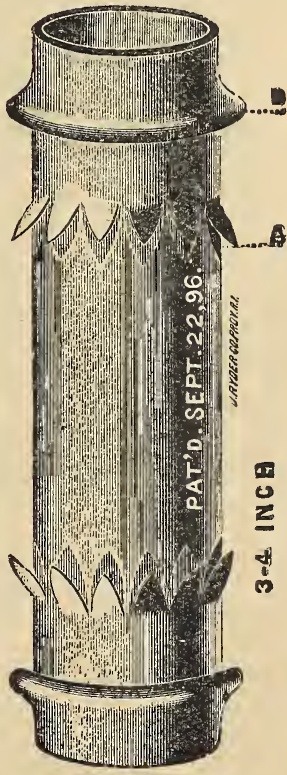

COOPER HOSE MENDER.

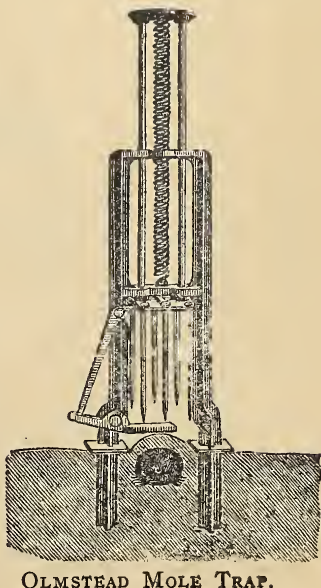

Olimstead MOLE Trat. 


\section{Leaf Racks.}

These are very liandy to carry leaves and cut grass from the lawn. Wood leaf racks on truck and without truck. Wire rack. Price, on application. Rack only.

\section{Grass Edgers.}

We carry a line of edgers superior to any in the city, Capitol Trimmer, Mower and Edger, Planet, Jr., Edger, Rotary Lawn Edger, Wallingford and Our Handy. Prices, 65c. to $\$ 8.50$.

\section{Horse Lawn Boots.}

These boots are indispensable where horse mowers are used on the lawn. Our boots are made of the best leather and are the most up-to-date boots on the market. Price, $\$ 20.00$ set.

\section{Lawn Rakes.}

Wood, iron or steel, in any size. Automatic, self-cleaning. A backward stroke cleans it entirely. Prices, $35 \mathrm{c}$. to $\$ 1.00$.

\section{Grass Catchers.}

We carry a full line of galvanized wire and cloth catchers. We constantly carry a stock of catchers to fit any mower. Prices, $\$ 1.25$ to $\$ 3.50$.

\section{Queen Lawn Rake.}

Lawn Queen. Wire tooth rake, very handy because it is reversible. Prices, $75 \mathrm{c}$. to $\$ 1.00$.

\section{Steel Lawn Rakes.}

Steel Lawn Rakes. In any size desired. Price, $85 \mathrm{c}$. to \$1.25. Malleable Iron Rakes. Price, 35c. to $85 \mathrm{c}$.

\section{Rubber Hose.}

For lawn, garden and street use. We carry a complete line of hose in all lengths, the best grades that will give line of hose in all lengths, the best grades that will give
good service and which we know will give satisfaction. good service and which we know will give satisfaction.
Our best grade hot-house hose will last for years. Different grades, I 2 c., I 4 c., I 6 c. and $18 \mathrm{c}$. per foot.

\section{Perfect Clinching Hose Mender.}

It slips into the hose and is clasped down; it cannot get loose. Price, roc.; $\$ 1.00$ doz.

\section{Grass Hooks.}

We carry a vast assortment of this tool for you to select from. We are the only importers of genuine Austrian grass hooks in the city. Adjustable and English riveted grass hooks also. Price, 45c. to $75 \mathrm{c}$.

\section{Hedge Shears.}

These shears are of the best English makes, with an excellent hang, with or without notch. The notch is at the heel of the blade and is for cutting small branches. Grass or sheep shears in great variety. Price, $\$ 1.25$ to $\$ 4.00$.

\section{Chisel Blade Weeder.}

Price, 35c.

\section{Weed Pullers.}

The Hall Weed Puller is absolutely the best instrumient for pulling dock, planten, crab-grass or any other undesirable growth in the lawn. 50c. to \$1.00.

\section{ENGINES-Our Stock is Very Complete The $\mathrm{E} \& \mathrm{~B}$}

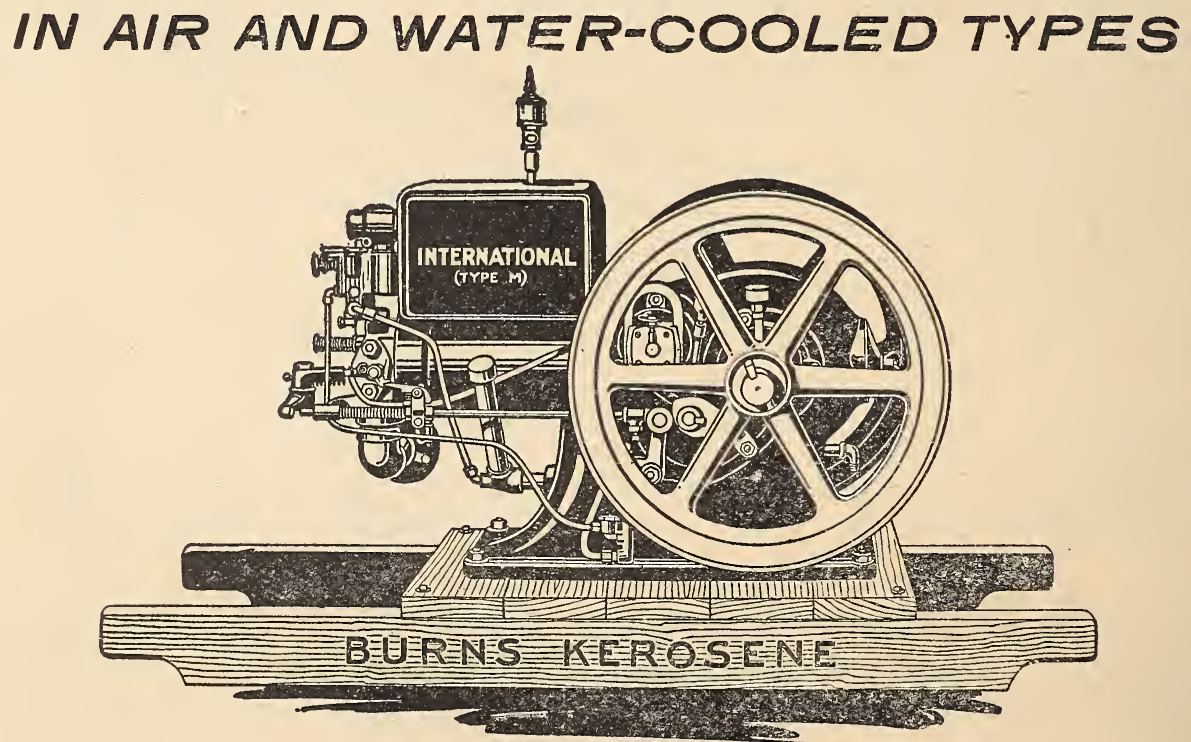

THE WELL-KNOWN WATER COOLED

\section{UNITED}

Is also sold by us, along with the very efficient and high quality

\section{International Type "M" 11/2, 3, 5 H. P. .}

1 his engine is made of the finest materials and is unsurpassed by any of the higher grade engines.

Our stock consists of all sizes, from $\pi \frac{1 / 4}{\mathrm{H}}$. P. to $25 \mathrm{H}$. P. in the above-named high-grade engines.

We carry a large stock of the various makes to op erate your water system, water pumps, spray apparatus. saws, washing machines, etc. It is our policy to give our engines the best of care, and, we are so prepared 1.... we can attend to your wants immediately. 


\section{TOOLS FOR THE GARDEN}

\section{PLANET, JR., GARDEN AND FARM IMPLEMENTS.}

WE WANT TO CALL YOUR PARTICULAR ATTENTION TO THE NEW PLANET, JR., WHEEL HOES THEY ARE MADE, NOW, IN THE HIGH-WHEEL, STYLE. NOTICE THE NEW ILLUSTRATIONS.

No. 16, SINGLE WHEEL HOE. -1 Plow, 2 Hoes, 3 Cultivator Teeth, 2 Rakes and Leaf Lifter, $\$ 10.25$.

No. 17. SINGLE WHEEL, HOE, -1 Plow, 2 Hoes and 3 Cultivator Teeth, $\$ 8.75$.

No. $17 \% 2$, SINGLE WHEEL HOE. $\rightarrow 2$ Hoes, 3 Cultivator Teeth, $\$ 7.60$.

No. 12, DOUBLE WHEEL HOE.-2 Plows, a Hoes, 4 Cultivator Teeth, 2 Leaf Lifters, $\$ 12.50$.

No. 13, DOUBLE WHEEL HOE.-2 Six-inch Hoes. $\$ 9.00$.

No. 14 , DOUBLE WHEEL, HOE. $\rightarrow$ Set Disc Hoes, 2 Three-Pronged Cultivator Teeth, 2 Plows and 2 Leaf Lifters, $\$ 14.00$.

No. 3r, WHEEL HOE AND DRILL.-\$13.00.

No. 31, DRILL ONLY.-\$10.50.

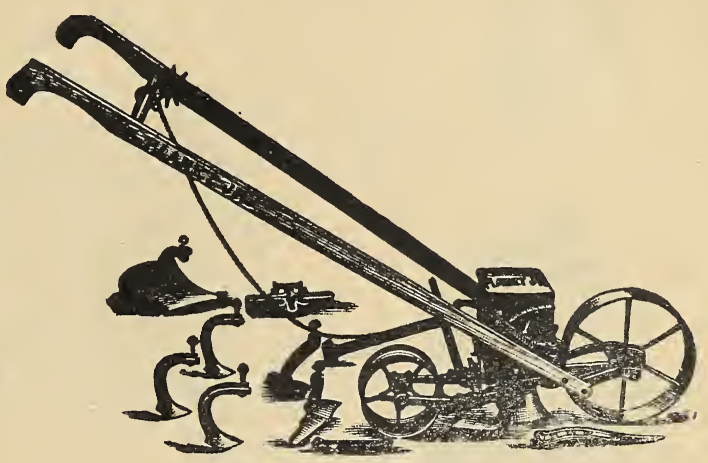

Single WheEL HoE.

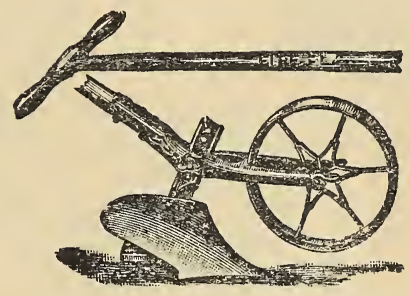

Fire-Fly Garden Plow.

No. 9, HORSE
Wheel only, \$17.00.

No. 4, COMBINATION HILL, and DRILL SEEDER. -With" Single Wheel Hoe, complete, \$19.50.

No. 4, As Seeder only, $\$ 15.50$.

No. 25, COMBINATION HILL and DRILL SEEDER. -With Double Wheel Hoe, complete, \$23.00.

No. 3, HILL AND DRILL SEEDER.-\$18.50.

No. 8, HORSE HOE and CULTIVATOR.-With Deep Regulator and Expander, complete, \$19.50.

FIRE-FLY HAND PLOW.-A very useful tool for the small garden. $\$ 4.50$.

FLANET, JR., CELERY HILLER.-Double, \$31.50.

Cash discount of to per cent. will be allowed on any Hand Tools.

\section{IRON AGE GARDEN AND FARM IMPLEMENTS}

No. 320, SINGLE WHEEL HOE.-2 Side Hoes, Cultivator Teeth, 2 Weeders and Leaf Lifter.

NEW MODEL SEED DRILL.-Fully equipped with marker.

No. I, COMBINATION HARROW and CULTIVATOR.-With Wheel. Without Wheel.

“BATEMAN' HAND-PULL PLOW.-A very handy tool for the small garden.

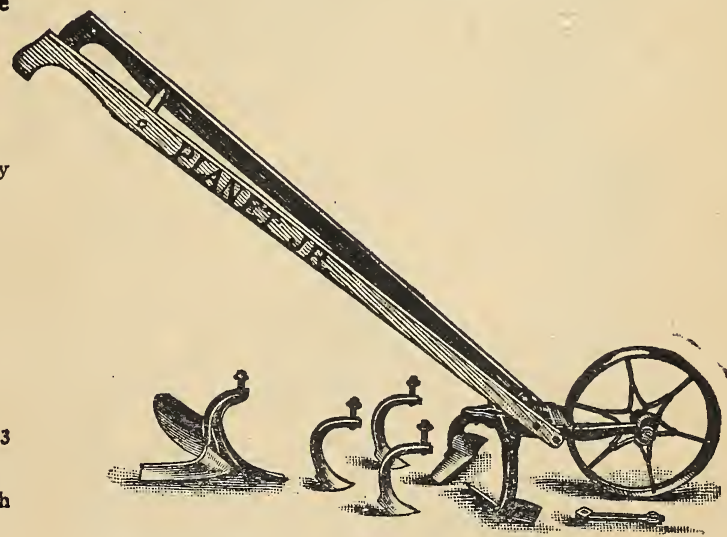

COMBINED HILL AND DRILL SEEDER, DOUBLE AND SINGLE WHEEL HOE, CULTIVATOR AND PLOW.

NEW MODEL GARDEN DRILL, as Drill complete. 


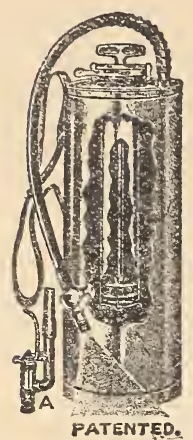

BRowN SPRAYER.

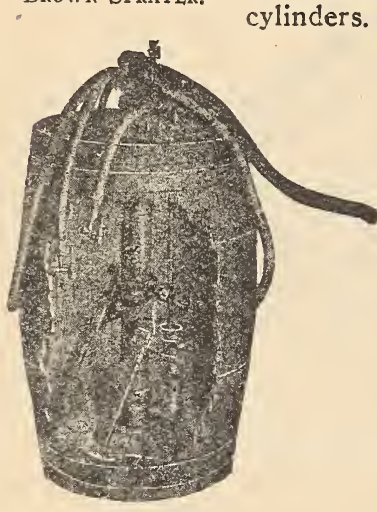

BARREL SPRAYFR。

\section{SPRAY TOOLS}

Prices on Application

Spraying has now become a necessary adjunct to the production of good crops, whether it be fruit, vegetables or flowers. We have in stock and ready for delivery any size pump from that used in a bucket to large hydraulic and power outfits in the Myers, Iron Age, Field Force Pumps.

Send for special catalogue on large outfits and spraying information.

\section{MYERS LINE}

LITTLE GIANT BRASS SPRAY PUMP.-For general use and white-washing.

IMPERIAL BRASS PUMP.-For general use with three PERFECT BUCKET SPRAY PUMP.Complete with hose and two nozzles. Brass, with three cylinders.

DEFIANCE BUCKET SPRAY PUMP.Brass, with hose and graduating Vermorel nozzles, fine, coarse spray and solid stream.

PERFECT KNAPSACK SPRAY PUMP. -Fully equipped, in galvanized tin, and brass.

WHI'TEWWASH SPRAYER.-Complete with agitator, extension and nozzle.

IMPROVED BRASS BARREL, SPRAY PUMP.-Complete with hose and nozzle.

COG-GEAR HYDRAULIC SPRAY PUMP. - Pump with suction hose complete, two lead hose, pipe extension and nozzle.

DOUBLE-ACTING COG-GEAR SPRAY OUTFIT

Fifty-gallon barrel mounted horizontally on skids, complete with 15 feet of $\pi / 2$-inch hose and extension.

DUPLEX COG-GEAR HAND SPRAY PUMP.Complete pump alone, double acting and vertical cylinder.

\section{GRASSELLIE'S AND MECHLING'S LIME. SULPHUR SOLUTION.}

In Barrels or by the Gallon.

\section{MECHLING'S SPRAY OILS. \\ PRATT'S SCALECIDE.}

In Barrels or by the Gallon. Ask for prices at once. SPRAY NOZZLES AND EXTRAS.

VERMOREL SPRAYER.-This is a French knapsack sprayer. It works on the compressed air principle, is very simple in construction; made of copper and holds five gallons. It is absolutely the finest sprayer on the market to-day. Price $\$ 25.00$.

IRON ACEE WACON FOUR-ROW SPRAYING ATTACHMEINT.-Attachment comp!ete with four nozzles, hose, connections and brackets.

ALL STYL.ES.-Vermorel, Bordeaux and Cyclone nozzles. Price, 35 c. to $\$ 3.25$.

POWER AND HAND NOZZLES.

PIPE EXTENSIONS

BAMBOO EXTENSIONS.

AUTO-SPRAYER-Brass, with hose and two nozzles. Galvanized. $\$ 6.00$ to $\$ 10.00$.

BANNER SPRAYER.-Brass, hose and two nozzles.

SYRINGES OR ATOMIZERS.-Tin, small; glass. galvanized, with compression. Brass, with compression. Price, 45 c. to $\$$ r.25.
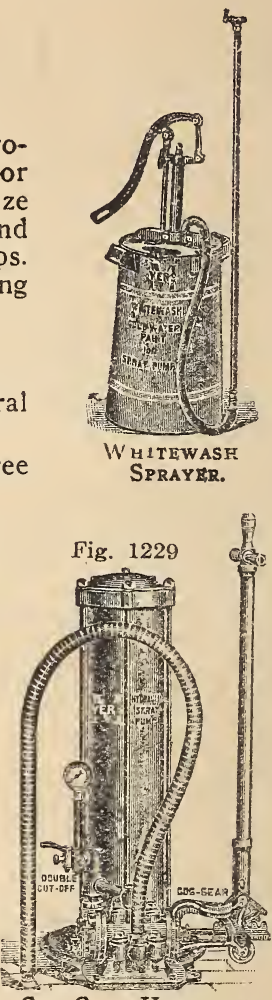

Cog Grar Hydraulic SPRAY PUMP.

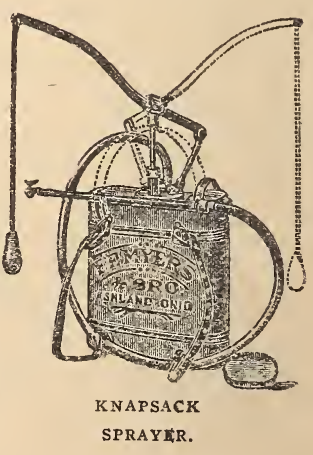




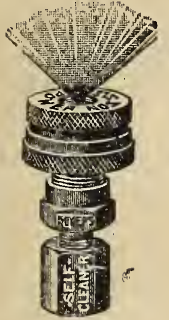

PAWDER NOZZLE SLLF-CI,EANER.

\section{DRY POWDER DUSTERS}

TIN DUSTER.-Dry powder spreader.

LEGGETTS "CHAMPION" INSECTICIDE DUSTER. HAND POWDER GUN.

FARMER ACME BELLOWS.

DICKEY DUSTER.

DRY POWDER BLOWER.

FEENY MODEL B DUSTER.-For garden work.

AMERICAN BEAUTY DUSTER.-For orchard and field work.

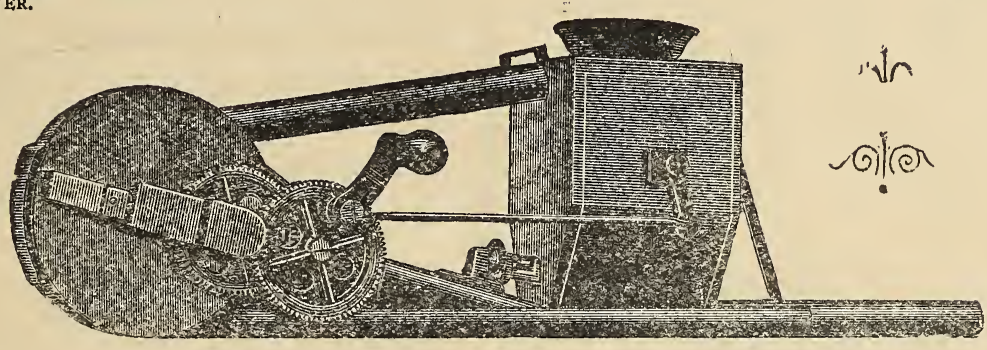

Champion Powder Gun.

\section{TOOLS}

Our aim is to carry the best tools used in the pursuit of all branches of Agriculture, Horticulture, Pomology, etc.

ASH CANS.-Heavily galvanized, braced or unbraced, with or without lid. \$1.50 to $\$ 4.00$.

ASPARAGUS BUNCHERS. - Shangle and Acme. Price, $\$ 1.75$ to $\$ 3.25$.

ASPARAGUS KNIVES.-All makes. 30c. to $45 \mathrm{C}$.

AX列S-Any weight desired. $\$ 1.50$ and $\$ 2.00$.

BASKETS.-Oak, Bamboo and Splint. Sizes, $1 / 2$ bu. to 3 bu. 4 C. to $\$ 1.50$.

BASKETS, HANDLED.-Oak, Bamboo, Splint Wire bound or plain. 5c. to $\$ 1.50$.

\section{BERRY HOOK. $-50 \mathrm{C}$.}

BILL HOOK.-Short Handle and Long Handle. $\$ 1.25$ to $\$ 4.00$.

BILL, PICKS.-American, No. 4. \$3.50.

BRUSHES.-For dairy purposes, 25c. to $60 \mathrm{c}$. for stable use, $25 \mathrm{C}$. to $\$ 3.50$; for white-washing 25c. to $\$ 2.00$.

BroOMS.- Stable push rattan and cocoa, $70 \mathrm{c}$ to 1.25: upright corn and rattan, 85c. to \$1.25: upright rattan, $75 \mathrm{c}$. to $\$ 1.35$.

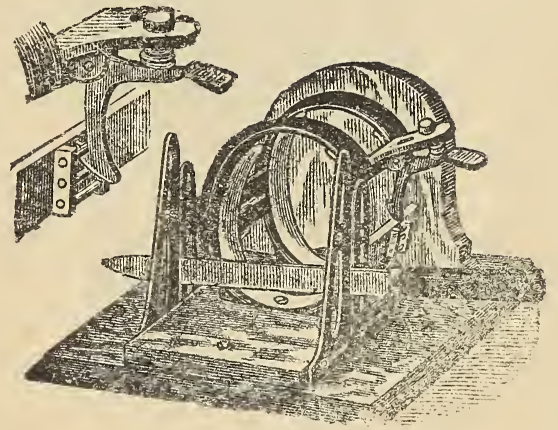

Acme Asparagus Buncher.

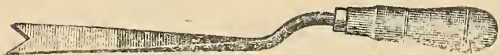

Concave Asparagus Knife.

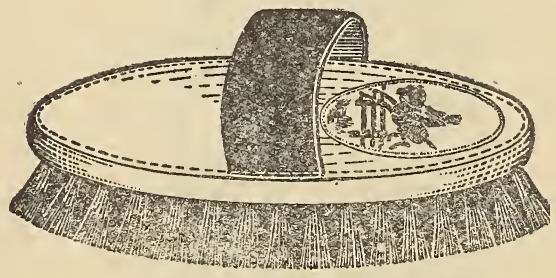

Horse Brush.

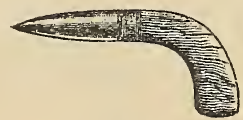

DIBBLE. 


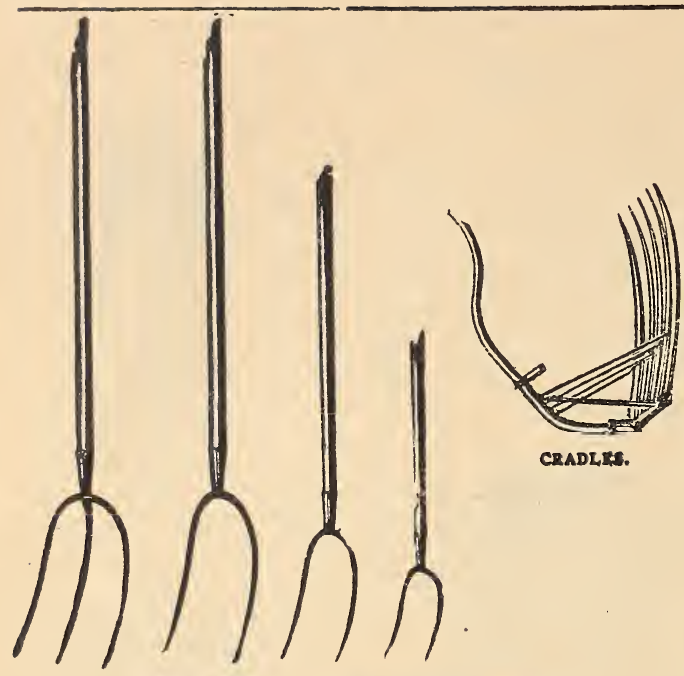

HAY FORKS.
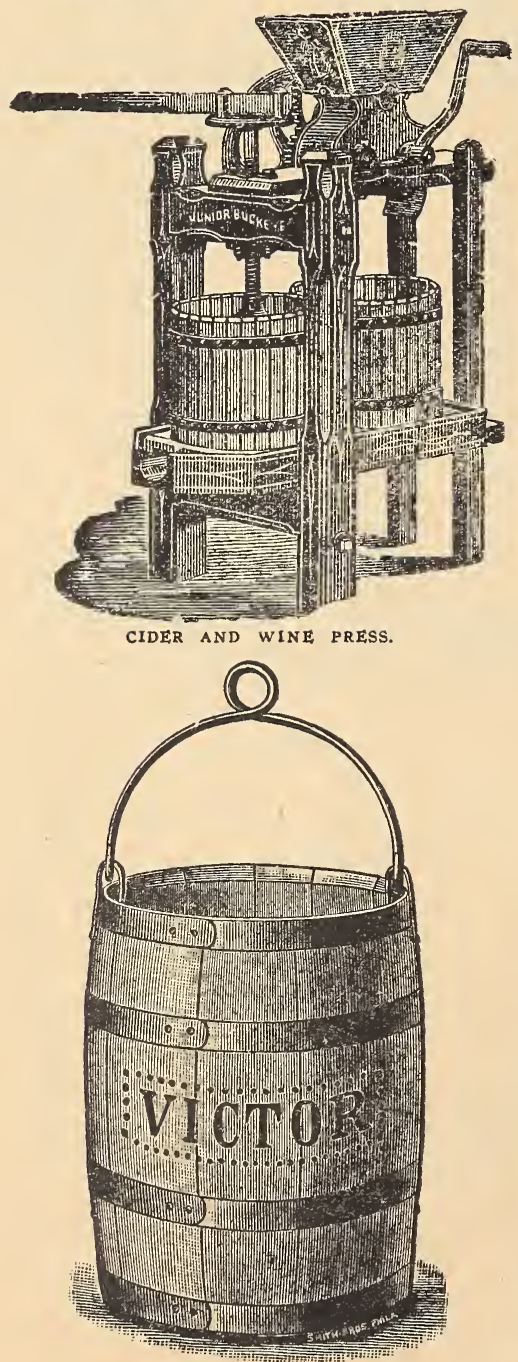

WELL BUCKET.
BRUSH AXE.-For shrubbery and underbruah \$1.as to $\$ 1.75$.

BUCKETS.-For all purposea. Wood, 9oc, to \$r.50.; Galvanized, $65 \mathrm{c}$. to $\$ 1.00$; Tin, 60c. to $\$ 1.25$. Well buckets, \$1.00 to $\$ 2.00$.

CABBAGE CORERS.-Made of the best of ateel. $8 \mathrm{ga}$

CALF WEANERS.-For calves and yearlings. Rice make. $35 \mathrm{c}$. to $75 \mathrm{c}$.

CANT HOOKS.-In all sizes and weights. \$1.30 to $\$ 2.50$.

CAPONIZING SET.-Complete. \$2.30 to \$4.30.

CATTLE CARDS.-I5C. and 25C.

CIDER MILLS AND WINE PRESSES,-Keyetode made. $\$ 4.50$ to $\$ 28.00$.

CURRY COMBS.-roc to ssa

CORN BREAKERS.-10C.

CORN KNIVES.-25C. to $50 \mathrm{C}$.

CROWBARS. $-\$ 1.00$ to $\$ 2.25$.

DEHORNERS.-Phillips and Webster make. \$8.30.

DIBBLES.-Wood handle, with iron point. 35c.

DOG CHAINS.-Light and heavy. 25c. and $30 \mathrm{c}$.

DOCK EXTRACTOR.-Heavy Hall. soc.

FILES. $-5 \mathrm{c}$. to $50 \mathrm{c}$.

FORKS.-Hand weeding.

Digging or spading, 4-prong, D handle, 6oc. to $\$ 1.25$. Digging or spading, 5-prong, D handle, $\$ 1.25$ to $\$ 2.50$. Manure fork, 4 tine, long handle, goc. to $\$ 1.30$.

Manure fork, 4 tine, short D handle, 9oc. to $\$ 1.35$.

Manure fork, 6 tine, short $D$ handle, $\$ 1.35$ to $\$ 1.75$ Hay forks, 2 tine, 3 tine, 4 tine, 6oc. to $\$ 1.25$.

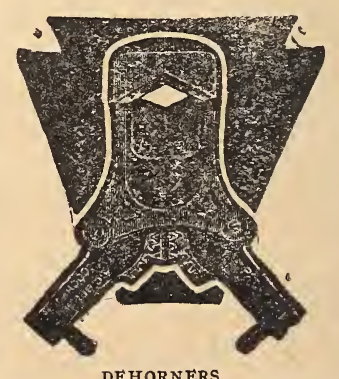

DEHORNERS.

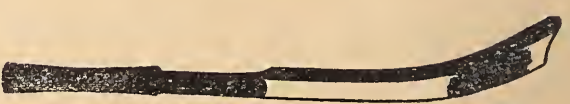

$\cos x$ xNIFt 
FRUIT PICKER.-Wire 35c. Pole for anme $20 \mathrm{C}$ to $45 \mathrm{C}$.

GARBAGE CANS.-Heavily galvanized, with or without bale. $\$ 1.25$ to $\$ 4.00$.

GARDEN LINE.-Best grade cotton. 45c. per lb.

GARDEN LINE REEL.-Malleable iron. \$1.50 to

$\$ 2.50$.

GARDENERS' GLOVES.-Cotton, goat, etc. roc. to $50 C$.

GRASS HOOKS.-English rireted back, Austrian, Dutch, American and Little Giant. 25c. to $75 \mathrm{c}$.

GRAFTING WAX.-1/4 lb., 15c.; $1 / 2$ lb., 25c.; I lb., $40 C$.

GRASS EDGERS.-Big variety. 65c. to \$1.50.

GRAPE BAGS.-Wired. 45c. per 100.

GRINDSTONES.-In many sizes, plain and mounted.

HAMMERS, CLAW. $-\$ 1.00$ to $\$ 1.50$.

HANDLES.-For all kinds of shovels, hoes, forks, rakes, axes, etc. roc. to $50 \mathrm{c}$.

HAY KNIVES.-Lightning, for cutting hay. Fisher make. $\$ 1.00$ to $\$ 1.50$.

HANDY HOE.-It is adjustable and with it you can plow, hoe and pulverize. It also does the bending and stooping for you along with many other thingt. \$1.75.

HANGING BASRET. -Wire, 15c. to 45c.; Terra Cotta, 50c. to $\$ 1.00$.

HATCHETS.-Medium and heary weights. \$1.00 and up.

HEDGE KNIFE.-\$1.25.

HORSE MUZZLES.-Galvanized, 25c; copperized, $25 \mathrm{c}$. HORSE CLIPPERS. $-\$ 1.25$ to $\$ 2.50$.

HORSE CLIPPING MACHINE AND RNIPE GRINDERS. - $\$ 12.00$ to $\$ 14.50$.

HOES.-Draw or Field.

Warren.-Heart-shaped, finest garden hoe, all sizes. 65 c. to $\$ 1.25$.

Acme.-Weeding and cultivating, double and single prong. $40 \mathrm{c}$. to $\$ 1.00$.

Scuffle or Push.-Hoes of best imported steel. $40 \mathrm{c}$. to $85 \mathrm{c}$. Handles, 25c. extra.

Norcross.-Three and five-pronged cultivating hoe. 50c. to $\$ 1.25$.

Celery Hilling. $-4 \frac{1}{2}$-inch blade and up. 35c. to $75 \mathrm{C}$. Grub.-All styles and sizes desired. 35c. to $\$ 1.25$

Prong or Potato Drags.-Four or five-tine, round or flat. $\$ 1.00$ to $\$ 2.00$.

Half-moon Hoe.-Any size desired from three to eight inches. $60 \mathrm{c}$. to $\$ 1.00$

HOG SCRAPERS.-Round or oval. 25c. and $35 \mathrm{c}$.

HOTBED MATS. $\mathbf{\$ 2 . 5 0}$ to $\$ 4.00$.

HUSKING GLOVES AND PEGS.-10c. to 75c.

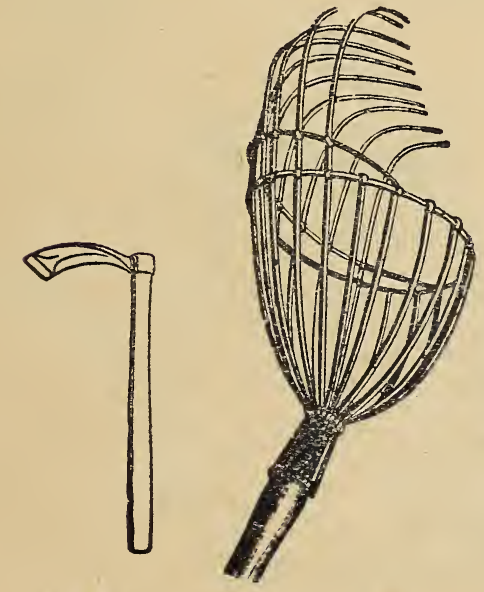

GRUB HOE.

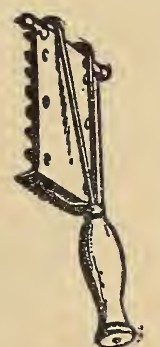

CURRY COMB.

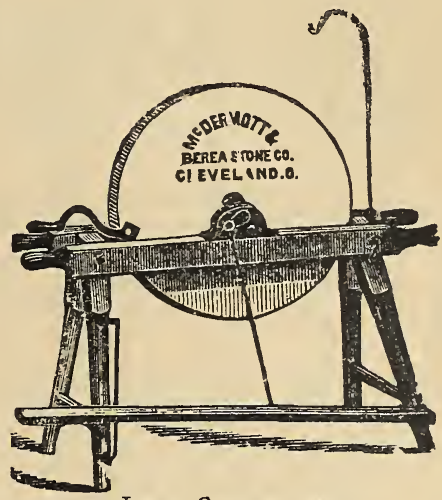

IDEAL GRINDSTONE.

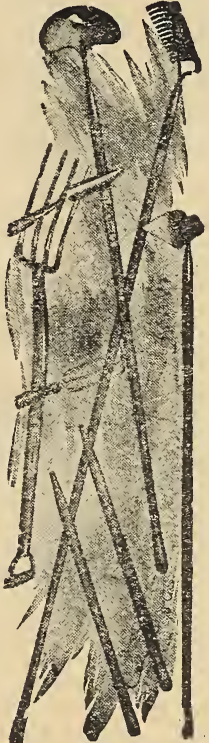

GARDEN TOOLS.

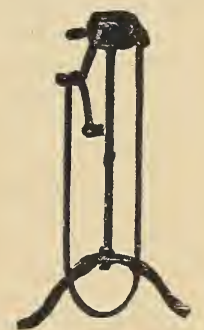

STEWART BALI,-BEARING Clipping MaChINE.

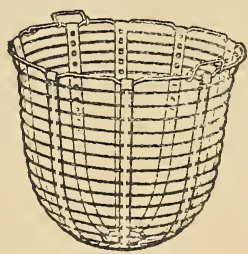

Horse MUZzLE.

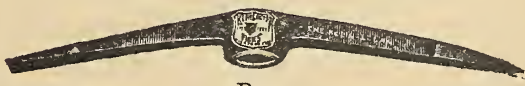

PrCK.

6oc. to $85 \mathrm{c}$.

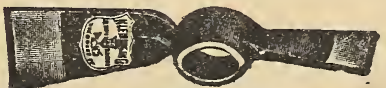

Mattox AxE, $65 \mathrm{c}$. to $85 \mathrm{c}$. 
ICE TOOLS.-Breaking bars, Caulking bars, Cansl chisels, Chain tongues, Cleaning-off scrapers, Hand tongues, Ice hooks, Ice plows, King's Ice scales, Ice planers, Ice saws, Snow scrapers, Splitting bars, Splitting fork, Starting chisels, etc. Prices on application.

KEGS.-Oak, in all sizes, from five to twenty-five gallon.

LABELS.-Wood, painted, for pots and garden use. Garden, 100 in pkg.; Pot, 1,000 in pkg. $\$ 1.55$ to $\$ 9.00$ per $\mathrm{I}, 000$.

LANTERNS.-Deitz, for all purposes and in all sizes. PosT-HOLE DIGGER. $\$ 1.00$ to $\$ 7.50$.

MAULE OR BEETLE.-All weights. For driving wedges, etc.; heavy, with iron bands, $\$ 1.00$ to $\$ 2.50$.

MEASURES.-Wood and galvanized, all sizes, from -ne pint to one bushel. 25c. to $\$ \mathrm{I} .40$.

GARDEN CULTIVATOR-HOES and WEEDERS.Material, workmanship and finish is of the highest quality. Prongs can be released without removing bolts. Sold with three and five prongs. A "Midget" weeder is also sold by us, which gives excellent service for flowers, strawberries, etc. 50c. to $\$ 1.25$.

OILS.-For lawn mowers, separators, gas engines, large machinery. From I pt. to I gal. or more. Ioc. per pt. to $75 \mathrm{c}$. per gal.

OIL, CANS.-Many styles. roc. to $35 \mathrm{c}$.

PICKS.-Clay, also Pick Mattock, Miners' picks. 6oc. to $85 \mathrm{c}$. Handles. I8c. to $50 \mathrm{c}$.

POST HOLE DIGGERS. $\$ \mathbf{1 . 5 0}$ to $\$ \mathbf{2 . 5 0}$.

PLANT STANDS.-Wire, 3-shelf square. \$3.73 to $\$ 7.00$.

PREPARED POTTING SOIL. $-\$ 1.00$ per bu.

PIANT BED PROTECTING CLOTH.-An article every gardener or trucker should have on hand. $15 \mathrm{c}$. to $25 \mathrm{c}$. per yard.

PRUNERS.-Water's Tree. A finely made pruner, sold in all lengths. $85 \mathrm{c}$. to $\$ 2.50$.

CRONK AND CARRIER.-This is a very handy and well-made pruner. $85 \mathrm{c}$. to $\$ \mathrm{r}$. 50 .

DISSTON.-This pruner head can be put up upon sny length pole, and is operated by a string. $\$ 1.50$ to $\$ 2.50$.

RAKE,S.-Short tootli, gravel, malleable or steel. $75 \mathrm{c}$. to $\$ \mathrm{r} .25$.

STEEL GARDEN RAKE.-7oc. to \$1.25.

AMES WOOD RAKE.-35c. to $75 \mathrm{c}$.

BOW STEEL RAKES. $\rightarrow$ 75. to $\$ 1.25$.

WOOD, GRAIN AND HAY RAKES.-35c. to 75C.

HUSTLER LAWN RAKE (WIRE), -34 teeth to 36 teeth. $6 x$. to $\$ 1.25$.

RAFFIA-Used exclusively for tying small vegetables. $15 \mathrm{c}$. per $1 \mathrm{~b}$.

RIVETS.-Pony, Rex, Spilt Brass, Tubular Japanned. roc. to $40 c$. per box.

RUBBER PLANT SPRINKLERS.-Straight neck, 2z., I2 oz. 50c. to \$2.00. Angle neck, 7 oz., 12 oz. $60 \mathrm{c}$ to $\$ 2.00$.

SAWS, PRUNING.-Double edge, 16-inch, 18-inch, 20-inch, 90c. to \$1.25. Single edge, 14-inch, 16-inch, 18-inch, 20-inch. 75 C. to \$1.50. Combined pruning and chisel for end of any length pole goc. to \$1.50.

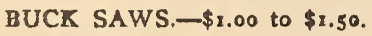

SAW BUCKS.-Made of wood. $75 \mathrm{c}$.
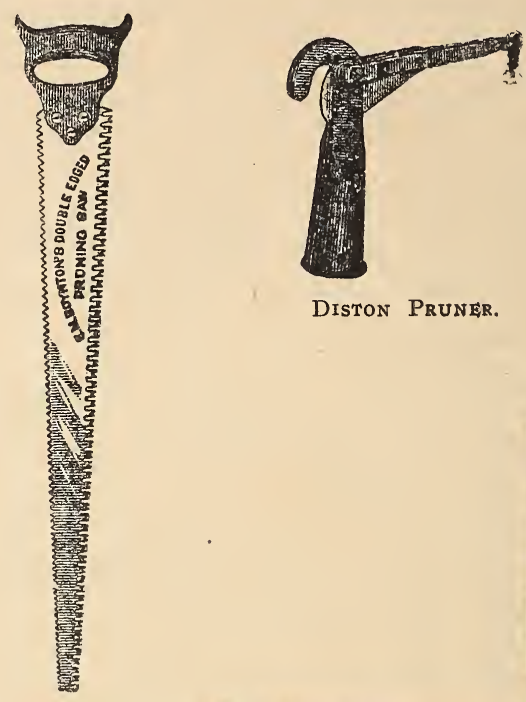

Diston Pruner.

Pruning Saw.

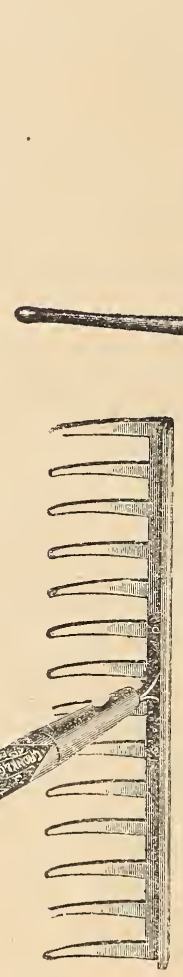

STEEL, RAKE.

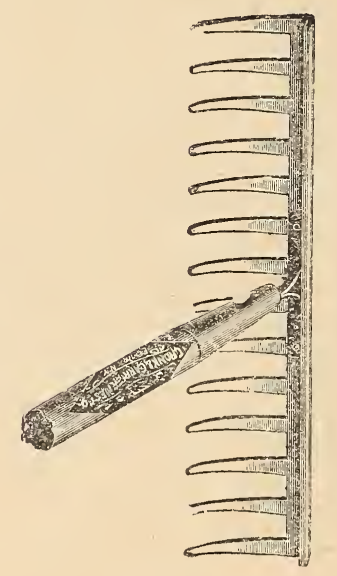

Post-HOLA DIGGER.

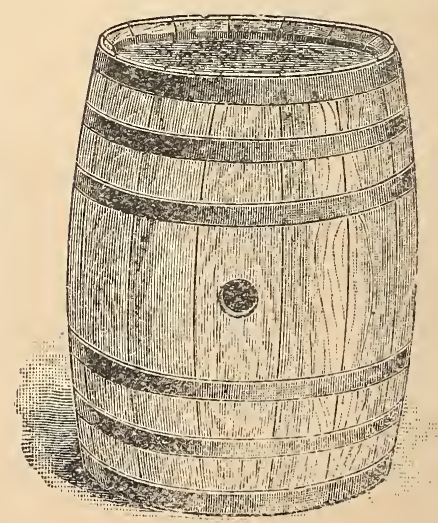

WINE KEG. 


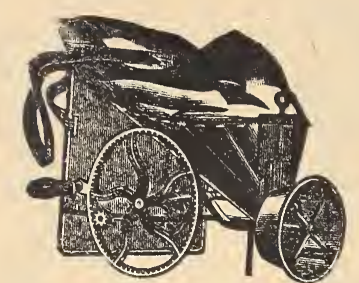

Calhoun Broadcast Seroer.

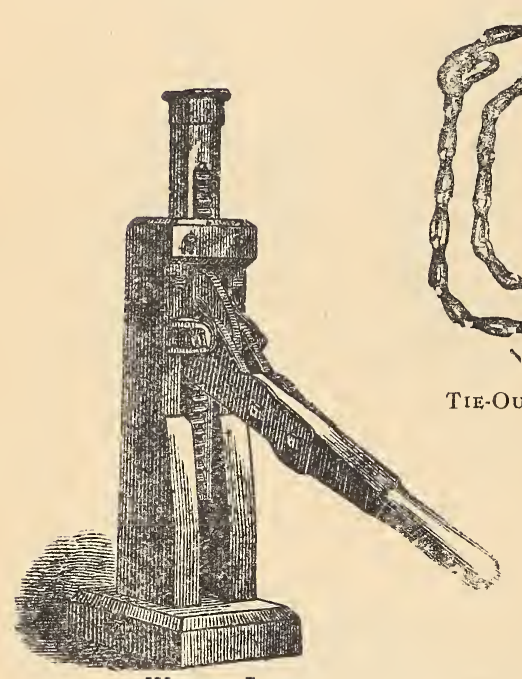

WAGON JACK.

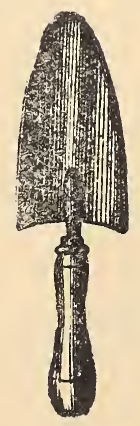

TROWELS.
TROWELS.-Special light, colid steel, with solid shank; English solid, Slim Jim for transplanting; and other transplanting. $5 \mathrm{c}$. to $60 \mathrm{c}$.

TIE-OUT CHAINS.-Light weight, $30 \mathrm{ft}$, $30 \mathrm{ft.}$ heavy weight, $20 \mathrm{ft}$. $30 \mathrm{ft}$. $75 \mathrm{c}$. to $\$ 2.00$.

TIE TWINE.- "Green Twist," permanent color; cotton, jute, two and three-ply; tar rope, Binder twine.

TORCH. - For burning caterpillars. 6oc. to \$2.50.

TRELLIS.-Galvanized Wire. 12 -inch, 15 -inch, 18 inch, 21 -inch, 24-inch, 36-inch, 48-inch, 60-inch, 72-inch, 90-inch, 108-inch, 120 -inch. $35 \mathrm{c}$. to \$3.50.

VINE OR FRANCIS WALL NAILS.-With lead lips to turn over vine, $11 / 2$ inches. \$1.50 per 100.

WATERING CANS OR SPRINKLING POTS.-Galvanized; two qualities, heavy and light, with galvanized or copper roses. I $5 \mathrm{C}$. to $\$ 3.00$.

WEDGES. - Steel, in assorted weights. 3oc. to $50 \mathrm{c}$.

WEEDERS. - Langs, Makefield and other hand and foot weeders. 25c. to $85 \mathrm{c}$.

WHEEL BARROWS.-Garden, Hothouse, Wood, contractor's; Steel, contractor's; Leaf barrow, Coal barrow.

\$3.50. upward. regular handle. Alligator. 25c. to $\$ 1.50$.

\section{FLOWER POTS, 8AUCERS, PANS AND TUBS.}

STANDARD FLOWER POTS.-Full inside meanre. ment. No charge for packing. Six at dozen rate; so at 100 rate; 500 at 1,000 rate.

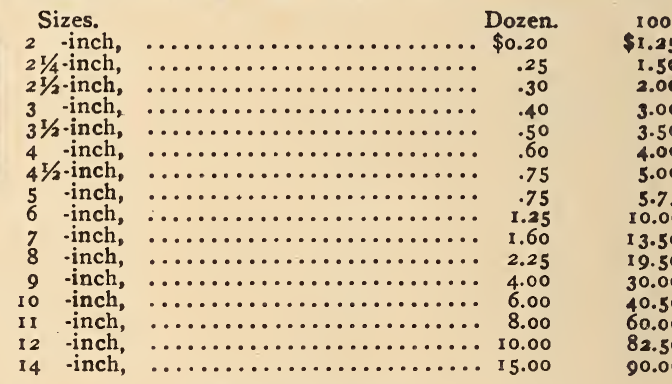
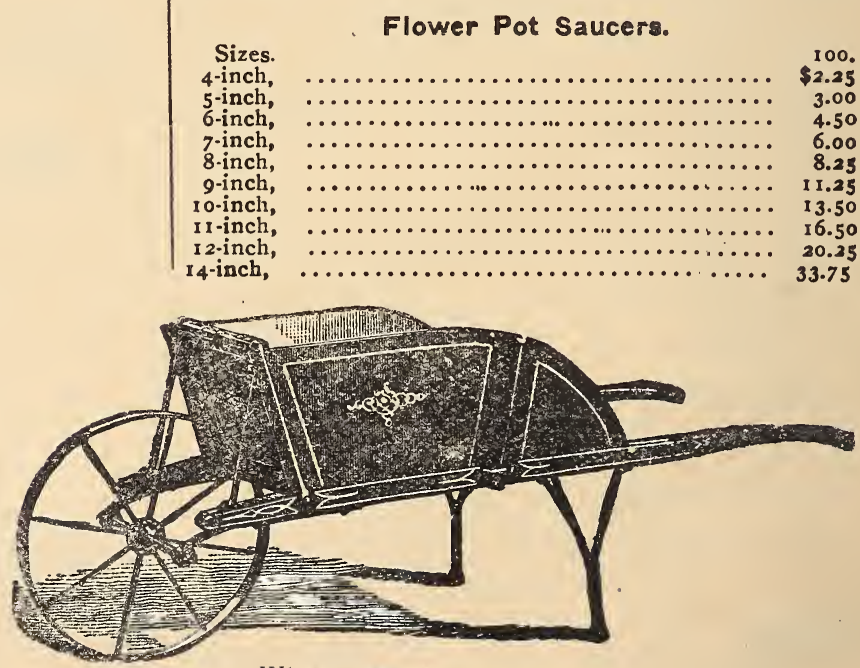

WHEELBARROWS

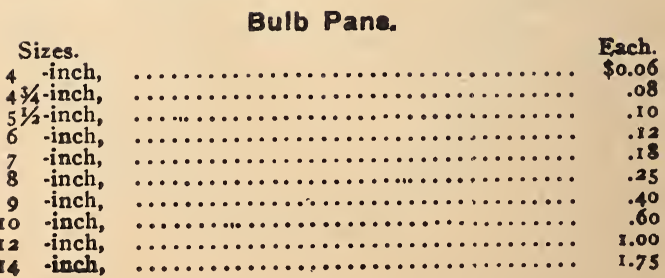


FERN DISH LINERS.-4c. to $20 \mathrm{c}$.

WOOD FIBRE SAUCERS.-8c. to \$1.50.

WOOD FIBRE ROLLING STANDS.-For heavy plants. $75 \mathrm{c}$. to $\$ 2.00$.

\section{PLANT TUBS.}

(Prices Subject to Change.)

CEDAR TUBS, REGULAR RICHMOND STYLE.Made of fine white cedar, with heavy cast feet and handles, and heavy flat-steel hoops. Tub painted green, hoops and feet black.

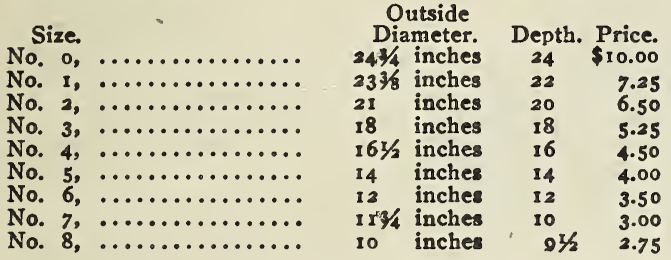

\section{NEW YORK STYLE TREE TUBS.}

Made of Virginia white cedar, painted green. Hoops, feet and handles painted black. Complete tub, trifle lighter than regular.

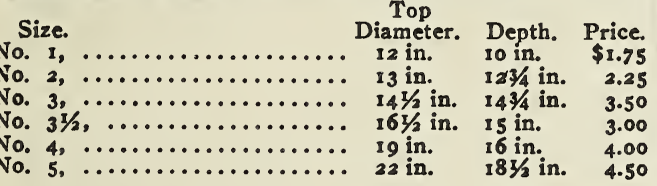

\section{PHILADELPHIA STYLE TREE TUBS.}

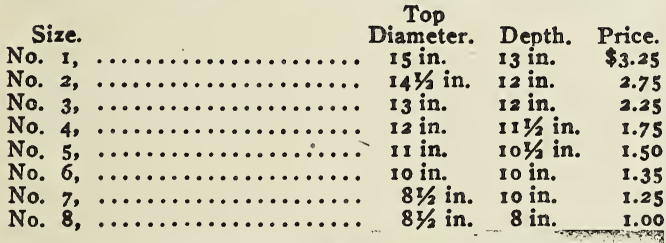

Made of Virginia white cedar, bound with three electric-welded wire hoops in grooves. The hoops will not break or fall off.

\section{RICHMOND STYLE TREE TUBS.}

The tubs are made of white cedar, bound with flat steel hoop at bottom and three galvanized hoops above. Nicely painted green.

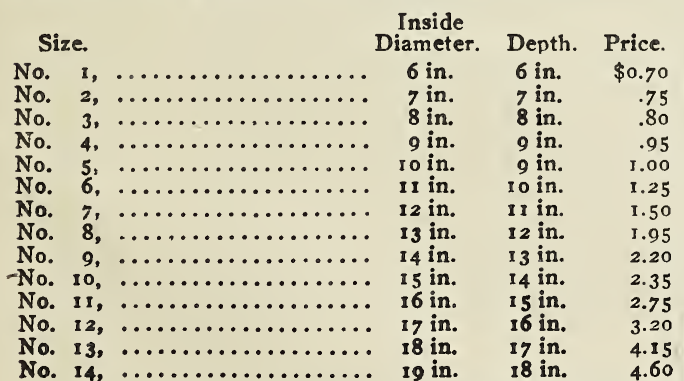

Prices on Dreer's Keystone Plant Tubs, Jardinieres and special size tubs upon application.

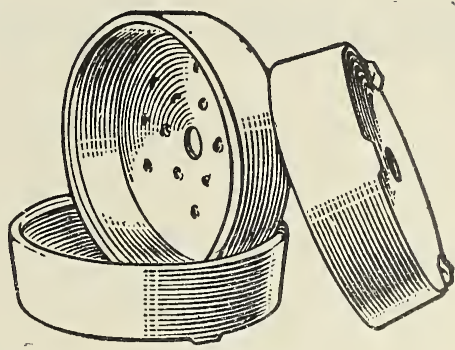

FERN PANS.

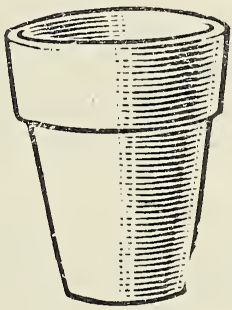

Standard Po't.

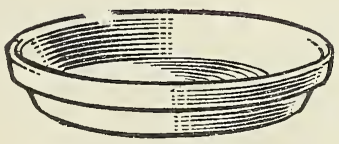

Standard Pot Saucer.

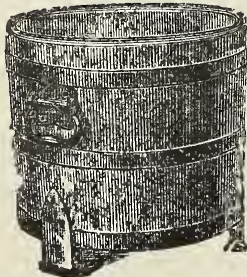

Plant and Tree Tub. 


\section{Cyclone Sanitary Wire Fencing}

Wire Fencing of All Kinds and Styles

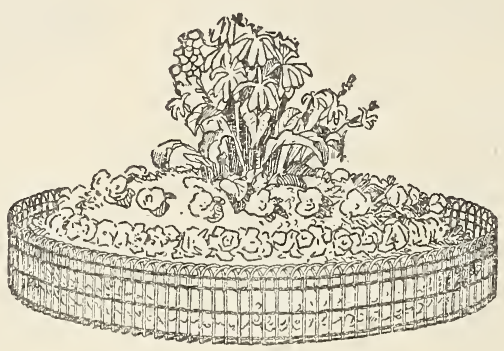

Lawn Fence.

Is our most popular and closest-mesh sanitary fence-opens up the yard to fresh air and sunlight, creating healthy playgrounds out of unsanitary back yards. Easily erected by anyone on ordinary wood posts and $2 \times 4$ top rail. Pickets No. 9 heavily galvanized wire spaced $27 / 8$ inches at top, I3/8 inches at bottom, making fence absolutely chicken-proof. Best heights are 36,42 and 48 inches.

PRICE PER LINEAL FOOT-STYLE “600.”-36-in ch, I5 cents. 42-inch, 17 cents. 48 -inch, I9 cents. Special prices in large quantities. $3 \mathrm{ft}$. Gate to match, $\$ 3.00$ and Upwards.

STYLE "I00."-Is exactly the same construction as Style "60o" above, except the additional lower pickets are not used. Pickets spaced $27-8$ inches apart, making a very handsome and inexpensive enclosure for any yard. Best heights are 36,42 and 48 inches.

PRICE PER LINEAL FOOT-STYLE “100."-36-inch, I3 cents. 42 -inch, 15 cents. 48 -inch, 17 cents. Special prices in large quantities. Gates to match, $\$ 2.50$ and Upwards.

CYCLONE FLOWER GUARD.-Fits any shape or size of bed. Bottoms of pickets left straight to be inserted in the ground.

PRICE PER LINEAL FOOT.-I6-inch, 8 cents; 22-inch, Io cents; 28 -inch, I 2 cents.

ALI, STEEL, $48 \times 12$ ft. FARM GATE, \$8.50. ALI, PRICES SUBJECT TO CHANGE WITHOUT NOTICE.
UNIVERSAL WALK GATE.-Strong enough for any yard, ornamental enough for any home. Heavy, high. carbon steel tubing non-breakable frame with Chickentight Style "6oo" Fabric.

Furnished with fittings to fasten to wood posts. Choice of 36,42 and 48 -inch heights. Price for 3 -ft. Opening, \$3.00.

"No Rust" All Galvanized Farm Gates, Factory and Cemetery Fences, Arches, Trellis, Tennis-Court Guards, Hitching Post, Flower Red Borders, Window Guards, Etc.

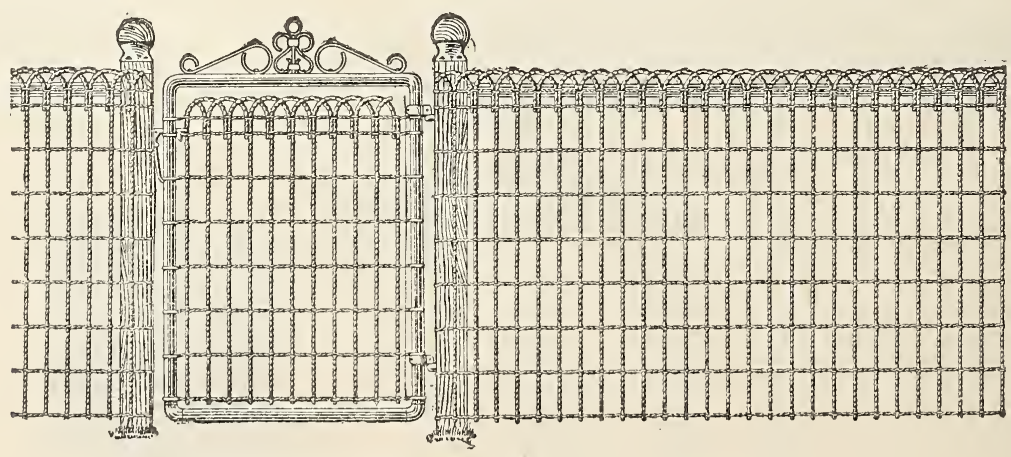

PRICES WILL BE GIVEN ON APPLICATION 
INSECTICIDES AND FUNGICIDE8.

\section{Prices subject to market fluctuation.}

Full directions with each package. Poisons and liquide not mailable

ANT-I.CIDE.-For ants in lawns; it drives them out. Non-poisonous powder for strewing on the infested surface. One pound will treat 300 square feet of lawn. $25 \mathrm{c}$. per pkg.

APHINE.-Kills plant lice of every description. A trong nicotine extract. $\$ 1.00$ to $\$ 2.50$ per can.

APHIS PUNK.-A nicotine paper for fumigating. 6oc. per box.

ARSENATE OF LEAD.-The best of araenical in. secticides; it will not burn foliage. Apply at rate of I lb. to 50 gal. of water. Prices upon request.

BLACK LEAF " $40 . "-A$ nicotine solution for spray. ing or fumigating. I oz. $25 \mathrm{c}$; ; $1 / 2 \mathrm{lb}$. $\$ 1.25 ; 2$ lbs. $\$ 3.75$; ro lbs. \$15.50.

BORDEAUX MIXTURE.-The very best remedy sgainst fungus, rust and rots. Apply I lb. to $50 \mathrm{gal}$ Water. $1 / 2$ lb 20c. and up. Prices upon request -A very excellent remedy for apple and pear trees, po tatoes, melons and cucumbers. If will beep roses free of mildew, black spot and insects of all sorts. I lb. 35c.; 2 lbs. $65 \mathrm{c}$.

BORDEAUX MIXTURE (LIOUID).-Add water-it is ready for use. One quart to 50 gal. water. For ungous diseases. I qt. 50c.; I gal. \$1.75.

BORDEAUX MIXTURE (DRY). - For dusting for

fungous diseases. Can be used as a spray. I lb. 40c.; 5 ths. \$1.50.

BUG DEATH.-A sure and safe remedy for all kinds of plant-eating pests. It kills bugs and worms; harmless to birds, animals, bees and flowers. I lb. I5c. Prices upon reques.

COPPER SULPHATE.-Used for early spraying and the making of Bordeaux. I lb. 25c. Prices upon request. CROW CORN OIL.-A non-poisonous oil for protecting newly planted corn. Will not kill birds. Will run through seeder. 25c. per pt: $40 \mathrm{c}$. per qt.

CUT-WORM KILLER.-Very alluring to cut worms.

It is non-poisonous to birds, fowl or animals. Box $25 \mathrm{c}$. FIR TREE OIL.-Destroys red spider, mealy bugs and aphis. $1 / 21 \mathrm{~b}$. 40c.: 2 lhs. $\$$ t.oo.

GRAPE DIIST.-Kills mildew indoors and out; also mites and molds. 5 lhs. $65^{\circ} \mathrm{C}$.

HALL'S NICOTINE FUMIGATOR.-A simple, effective fumigator for plant lice thrips, etc, in the greenhouse. I $1 \mathrm{~b} . \$ 1.00 ; 2 \mathrm{t} / 2$ lbs. $\$ 2.50$; ro $1 \mathrm{bs}$. $\$ 8.50$.

HELLEBORE.-Destroys insects and worms on currants, vines, roses and shrubs. $1 / 4 \mathrm{lb}$. 20c.; $1 / 2 \mathrm{lb}$. $35 \mathrm{c}$.; I $1 \mathrm{~b} .60 \mathrm{c}$.

INSECT POWDER OR DALMATION.-For fleas,

roaches, moths and ants. $25 \mathrm{c}$. per pkg. aphis, etc. I at. - 50c.; I gal. \$1.75.

LEMON OIL. - One of the most highly recommended insecticides for home and greenhouse use. It has a pleasant odor and destroys all insects and soft scales. I pt. 50c.: I qt. ooc.: $1 / 2$ gal \$1 50

LIME SULPHUR SOLUTION (LIOUID).-The best known of scale and fungous destroyers. Good on pears and peaches. Use during dormant season. I gal. 40c.; $\$ 12.00$ per bbl. Snecial nrice on quantity

LIME SULPHUR SOI.UTION (POWDER). - Used same as above. Dissolves entirely in cold water. 20c. per 1b.: \$T4.0n ner too ths

MELROSINE.-It kills rose bugs. It is a liquid spray. Does not discolor the flower and is non-poisonous. Pint can $\$ 1.00$; quart can $\$ 1.75$; $1 / 2$ gallon can $\$ 3.25$; gallon can $\$ 6.00$.

NICO FUME.-Paper made from high-grade nicotine solution. Hang up and light and it will destroy green fly, thrips, and all insects destroyed by tobacco. 24 sheets \$1.25.; 144 sheets, \$5.00.

NICO FUME (IIOUID).-Used for spraying and fumigating. Will kill most insects and scale. $1 / 41 \mathrm{~b}$. 50c.; I lb. $\$$ T. . $0: 4$ lbs. $\$ z 50$.

NIKOTEEN-Kills aphis, thrip, rosebug, green fly, plant lice, mealy bugs, etc. Bottle $40 \mathrm{co}$; $1 / 2 \mathrm{lb}$. $\$$ i.25; I lb. $\$ 2.00 ; 4$ lhs. $\$ 6.50$

PARIS GREEN.-Used for potato bugs and other eating insects. Prices unon request.

PINOL-LYPTOL. - The very newest and quickest method of destroying weeds, grass and other growth in garden walks, gutters, tennis courts, driveways, etc. Use one part to ten or fifteen parts water and spray just before nightfall. I gal. is 50; 5 gal. can, $\$ 7.50$

RAT CORN.-It petrifies the rat and leaves no odor. It is not poisonous to fowl or beat. $25 \mathrm{c}$. to $\$ \mathrm{r} .00$ per pkg. SCALESIDE.-A very good winter spray for scale. $\$ 1.00$ per gal.: $\$ 42.00$ per bbi., delivered at your station. SLUG-SHOT. - Sure death to the cabbage worm. It destruys all other insects also. I lb. carton $15 \mathrm{c}$. $5 \mathrm{lbs}$. $50 c$.

SULPHUR, POWDERED.-Used on steam pipes in paste form or for spreading on roses for mildew. $8 \mathrm{c}$. per lb.; $\$ 6.50$ per roo lbs.

TOBACCO DUST.-Used for dusting on plants to destroy insects. Ioc. per lb. Prices upon request.

TOBACCO SOAP. - A very good insecticide for general use. $15 \mathrm{c}$. per pkg. and up.

TOBACCO STEMS.-Used for fumigating, for cover ing lawns to furnish ammonia and drive away insects and moulds. 5c. per 16 .; $\$ 3.00$ per 100.

TREE TANGLEFOOT. -A sure remedy against caterpillars, Gypsy moths and other insects which climb the runk of a tree. I lb. 50c.; 3 lbs. \$1.45; Io lbs. \$4.50.

WHALE OR FISH-OIL SOAP.-Ussed during summer as a wash: stimulating to the plant and prevents ne spread of scale. $1 / 21 \mathrm{~b}$. I $5 \mathrm{c}$.; I lb. $25 \mathrm{c}$

WEED KILLER. - (See Pinol-Lyptol.)

WORM ERADICATOR.-It eradicates worms in greenhouses or potted plants, also from lawns, tenni courts, etc. 25c. per pkg.
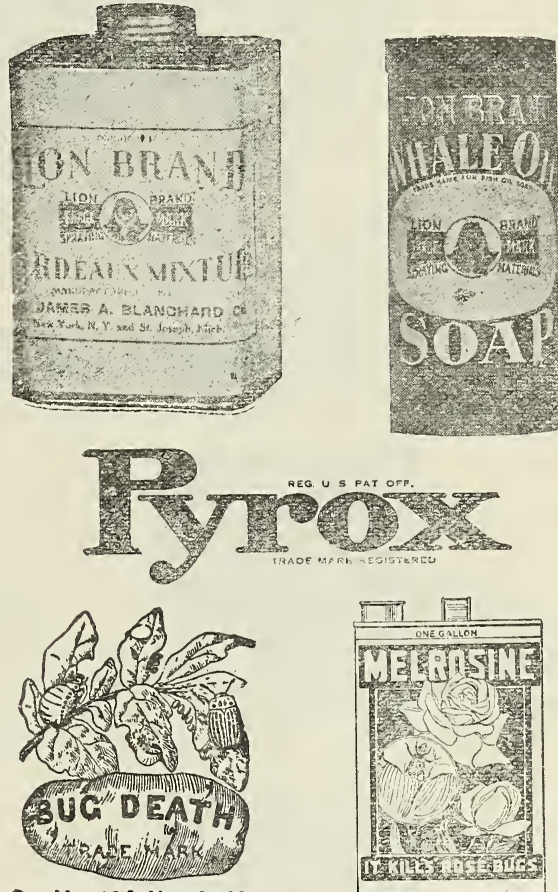

Pat. Mar. 16 \& Nov. 9,1897
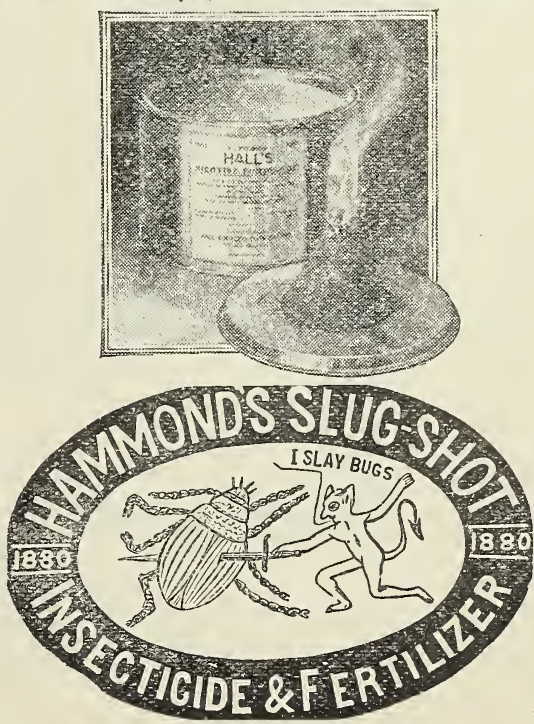


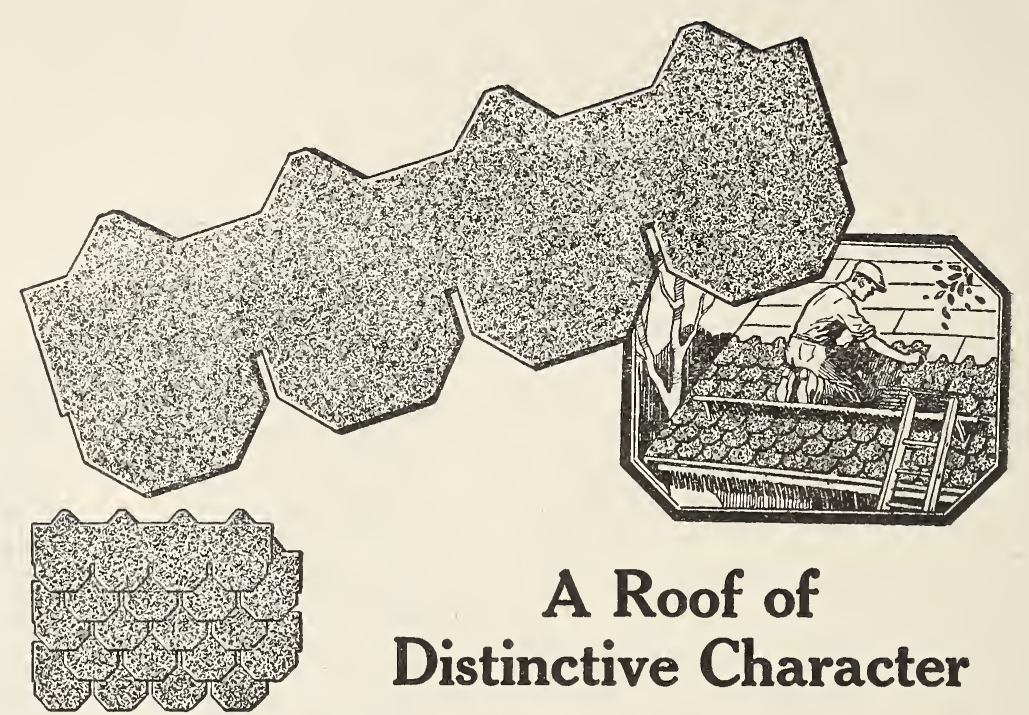

No longer need your home have a roof which looks like a thousand others. You can obtain distinctive and beautiful designs by the use of Ruberoid Strip-shingles.

We would like to have you come in to see samples of the full line of Ruberoid Stripshingles we carry. We want to show you how varied designs may be obtained.

The soft tones of rich red or cool sage green may be used alone or combined as you choose and by reversing the shingle courses the regularity of the roof lines can be broken up. Some of these designs are shown here-but lack of space and color make true reproduction impossible.

Let us show you a folder which describes this shingle fully and illustrates various designs in actual color.

course, requiring about $11 / 5$ squares (130 strips) per 100 sq.
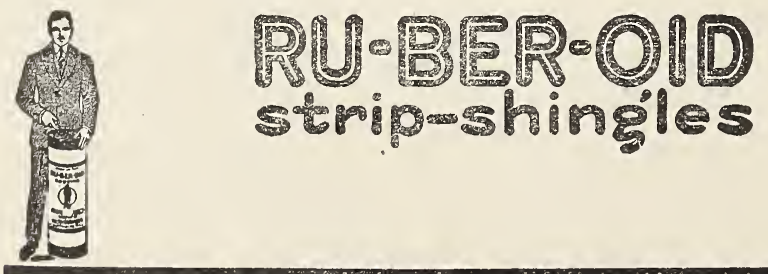


\section{ROOFING RU-BER-OID and KA-LOR-OID}

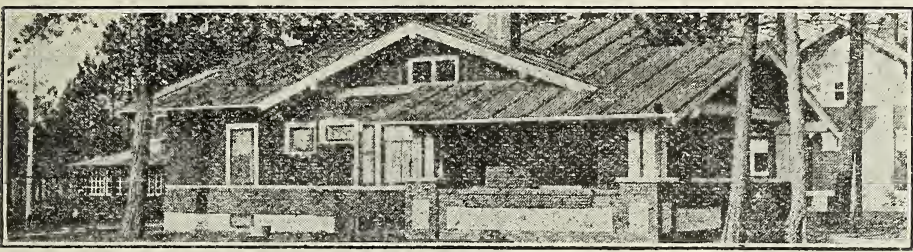

The Roofing that has stood the test for twenty years on buildings of all kinds and descriptions. Rain-Prool, Snow-Proof, Heat - Proof, Cold - Proof, Time-Proof,

\section{RU-BER-OID}

Accent on the "Ru" and always spelled with one "B." KA-LLY P PLY 2 PLY 3 PLY

A colored weather-proof roofing for homes, bungalows, etc., with the same properties as Ru-ber-oid. It will not lose its coloring, for the coloring is incorporated during the actual process of manufacturing-RED, BROWN, GREEN.

STAREX ROOFING.-A high-grade, ready-to-lay roof-

ing, suitable for all classes of buildings. \$I.25 per roll
ZYLEX ROOFING.-It is light and durable, easy to lay, inexpensive. Water and weather proof. $\$ 1.50$ per

All rolls contain 108 sq. feet. Cement and nails inside. "SLATEX".-A slate-covered Roofing in green and red. Extra heavy quaisty. Make a handsome roof for bungalow or othe1 houses. $\$ 2.50$.

Ruberoid Weatherproof Sheathing Slaters' Felt, Celery Paper, Rosin Sized Sheathing, 25, 30, 40 lbs. weights, Two and Three Ply Tar Paper, Roof Cement, Roofing Tar Paint, Nails, Etc.

Always use RU-BER-OID for your Poultry Houses, Sheds, Barns, etc., it is by far the best.

\section{Blue Hen Incubators and Brooders}

NEW PATTERNS, WITH MANY IMPROVEMENTS, ARE NOT EXCELLED. INCUBATORS.

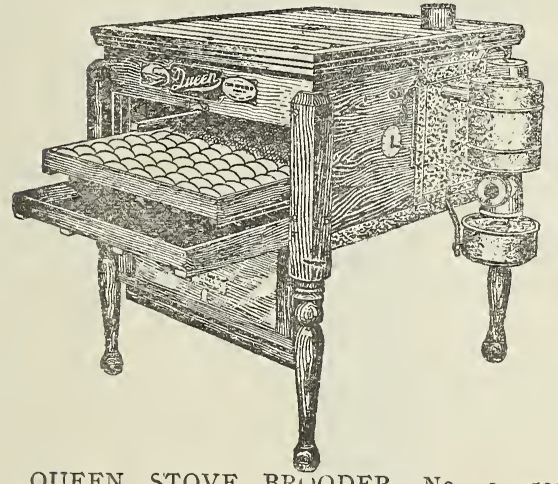

QUEEN STOVE BRUODER.-No. I, 500 chicks, $\$ 2$ I.50; No. 2, I, 000 chicks, $\$ 26.50$.

The Queen Incubator is of the "Hot-Water" type and very aptly meets the requirements of those who desire this kind. You can make no mistake in choosing this Incubator, as there is nothing that will even equal it in Ine "Hot-Water" type of Incubator. All sizes.

No. 20 , 70-egg size, $\$ 16.50$; No. I, 85-egg size, \$27.50; No. 2, I 35-egg size, $\$ 37.50$; No. 3, I80-egg size, $\$ 44.50$; No. 4,275 -egg size, $\$ 57.50$; No. 5, 40o-egg size, $\$ 68.00$. MAGIC STOVE BROODERS-200-chick size, \$22.00: 300-chick size, $\$ 27.00$.

\section{SIMPLICITY INCUBATORS AND BROODERS.}

Hot water combination incubator and brooder, very simple and efficient.-50-egg size, \$12; roo-egg size, $\$ 18$.

\section{- POULTRY SUPPLIES -}

Below we glve you as complete a list of poultry supplies and remedles as possible In thls space. We carry a much greater line, and prices will be cheerfully glven on application.

\section{POULTRY FOODS.}

Purina Chick; Perina Poultry; Oyster Shell, all sizes; Mica Grit, all sizes; Charcoal, all sizes; Beef Scraps; Alfalfa; Cracked Bone, all sizes; Kaffir Corn; Buck-

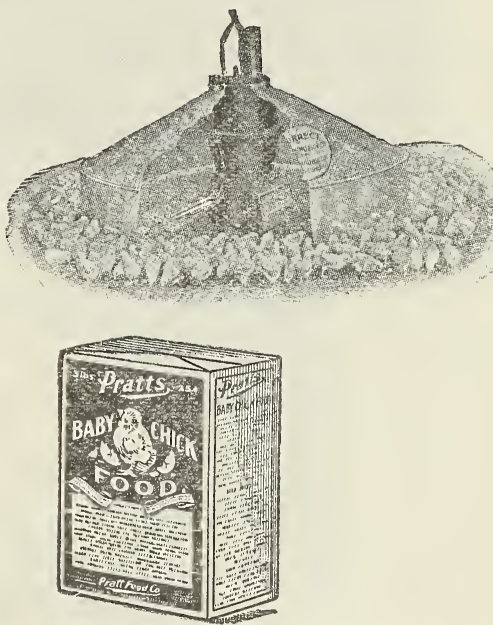

wheat; Millet; Sunflower; Hemp; Rape; Vetch Spring Feed; Poultry Mesh: Pratt's Chicorain; Canada Peas: Chick Chowder; Chick Manna; Conkey's Baby Chick Food; Pratt's Baby Chick Food.

The prices on these supplies are constantly changing; we will gladly quote you on any one of them by request. Brooder Thermometers, $35 \mathrm{c}$. to $50 \mathrm{c}$. each; Medicated Eggs, Knox, 3c. and 5c. each; 3oc. to 5oc. per doz. China Eggs, 4c. each; 4oc. per doz.

\section{Mann Green Bone Cutter.}

Frach.

Incubator and Brooder Lamps, ......75c. to \$1.00 each Standard Egg Tester, ....................25c each Banner Root Cutter, .......................... to $\$ 8.00$ Wilson \& Mountville Sheil Milis,...............\$6.00 Wilson \& Mountville Shell Mills, on stand, .........\$6.00 Perfection Corn Sheller, .....................\$2.35

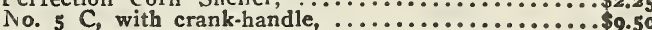
No. 5 B, with balance wheel .................. No. 7 best size for a yard of 100 hers and 07 es No. $7 / 2$, hand and power, .................. N.. 12, power only, ..........................\$5.00 


\section{POULTRY SUNDRIES.}

\section{Drinking Fountains, Hoppere, Feedere, Etc.}

Price Each.

Galvanized Wall Fountains, $\ldots \ldots \ldots \ldots \ldots$........ to $75 \mathrm{c}$. Peerless Galvanized Brooder Fountains,............ 30c. to 85c. Apex Galvanized Hinge Bottom Fountains, ..65c. to 85c. Folwel Galvanized Fountains, I qt., ...............35c. Apex Side Cups for Coops Galvanized,............... and 25c. Ribsam's Stoneware Drinking Fountains, $\ldots .18 \mathrm{c}$. to $45 \mathrm{c}$. Stoneware Drinking Fountains, ..........25c. to 65c. Norwich Automatic Air-Lock Fountain, ......... \$3.00 Galvanized Fountains, .................25c. to Goc.

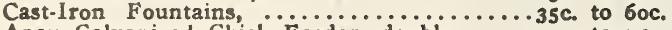
Apex Galvanized Chick Feeder, double, .....40c. to 75c. Apex Galvanized Chick Feeders, single, ......30c. to 75c. Cast.Iron Compartment Chick Feeders, ....3.3.c. to $\$ 1.25$ Apex Side.Wall Galvanized Box Feeders, ...30c. to $\$ 1.25$ Apex Side-Wall Galvanized Box Feeders, ..50c. to 75c. Folwel Sanitary Galv. Dry Mesh Feeder,..90c. and \$r.0o. Perfect Galv. Dry Mesh Feeder and Grit Box, 6oc. to $75 \mathrm{c}$. Norwich Automatic Feeder, ........... \$2.50 to $\$ 5.00$ Jersey Sanitary Dry Food Hopper,....... \$1.50 to \$2.50 Ideal Dry Mesh Feeder, ................

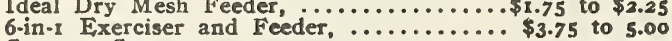
Conners Sprouters, ...................2.25 to 4.00 Aluminum Leg Bands (3 styles), 15c. per doz.; 65c. per I00.

Celluloid Leg Bands, ........20c. per doz.; 75c. per roo. Celluloid Pigeon Bands, ......I5c. per doz,; 6oc. per roo. Incubator Thermometers, ..........50c. to $\$ 1.00$ each.
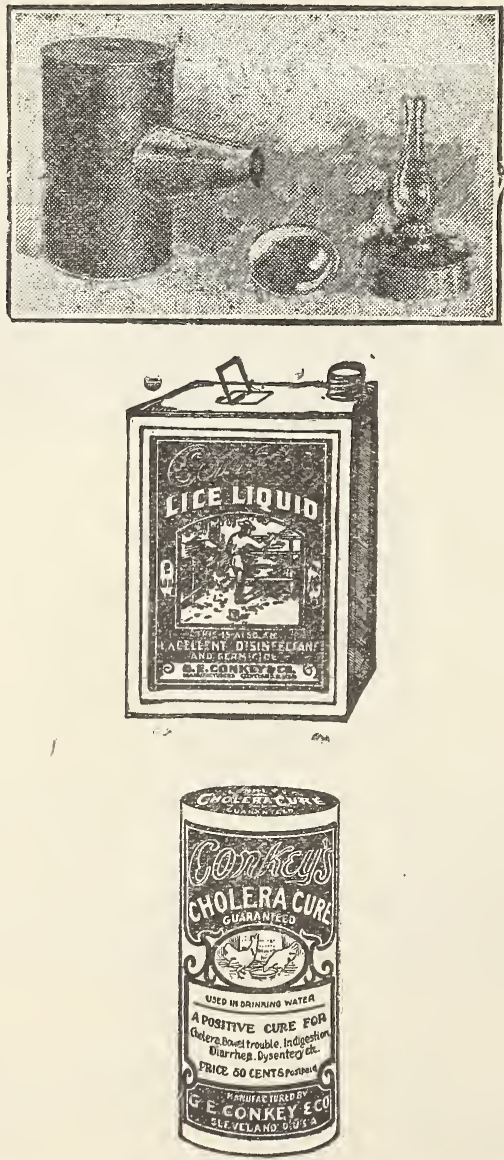

WE ALSO CARRY A COMPLETE LINE OF PRATT'S. RUST'S AND DR. HESS REMEDIES, PRICES AND CATALOGUE CHEERFULLY SENT ON APPLICATION.

\section{Pilling's Complete Line of Poultry Instruments.}

Price Pach.

Philadelphia Poultry Marker, ...................2sc.

French Poultry Killing Knife, .................50c.

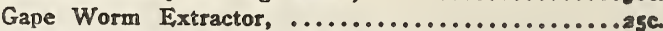

Horse-Hair Gape Worm Extractor, ...............

Pilling's Killing Knife, angular, ................ 5oc.

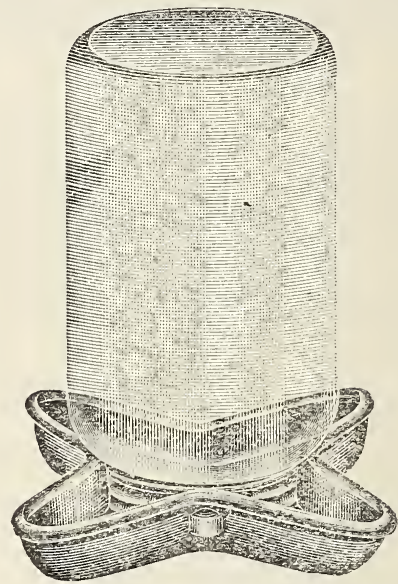

QUART FounTaIN.

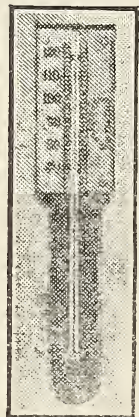

BROODER THERMOMETER.

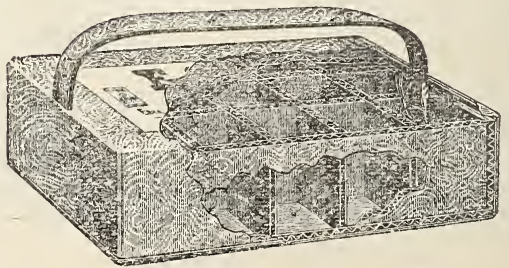

EGG BoxIS. 


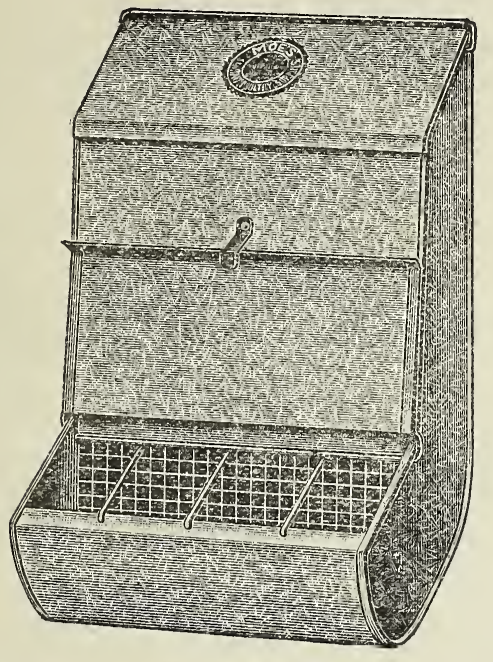

Galvanized DRY Mash FEEDERS.

\section{Dairy Supplies}

BOTTLE CARRIERS-Extra heavy material and heavily galvanized. Quarts and Pints. Price each, 85c. to $\$ 2.50$.

BOTTLES.

BOTTLE FILLERS.-Our filler is one of the best. $\$ 7.50$ to $\$ 85.00$

BOTTLE CAPS.-Skim Milk, Cream, Buttermilk and regular printed milk caps.

BOTTLE BRUSHES.-Regular and machine brushes of highest quality. 20c. to $65 \mathrm{c}$

BOTTLE-WASHING MACHINES.

BUTTER BOXES.- $\$ 2.25$ to $\$ 6.00$.

BUTTER PRESSES. - I5c. to \$10.00.

BUTTER WORKERS.-\$9.50 upward

BABCOCK'S TEST BOTTLES.-Milk, Cream and Skim Milk Bottles. 2oc. upward.

BAG BALM.-Per box, $65 \mathrm{c}$.

BARKER'S CATTLE' POWDER.-18c. per pkg.; 6 pkgs. for $85 \mathrm{c}$. Also new pkg., 25c

BLATCHFORD and RYDES CALF MEAL.-This is an excellent meal for the young stock. $25 \mathrm{lbs}$. for $\$ 1.75$. BUTTER PAPER.-In all sizes.

CHURNS.-Monumental, Improved and Babcock. \$2.25 to $\$$ I0.00.

COOLEY CANS.-Made of fine charcoal plate tin. CREAM CANS.-Made of fine charcoal plate tin. $85 \mathrm{c}$. to $\$ 2.00$

CREAM KETTLES.-For serving purposes, all sizes, blocked tin and iron clad. I5 c. to \$2.00. CREAM PANS.-Japanned, painted and plain. Price

CREAMERS. - \$1.00 to $\$ 6.00$.

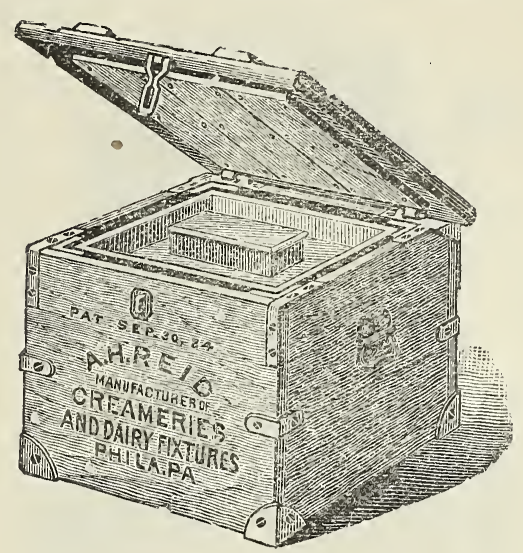

Borrat Box.

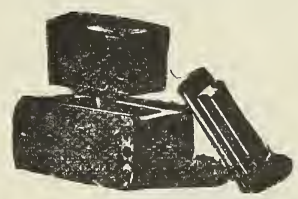

Hand Butugra Print.

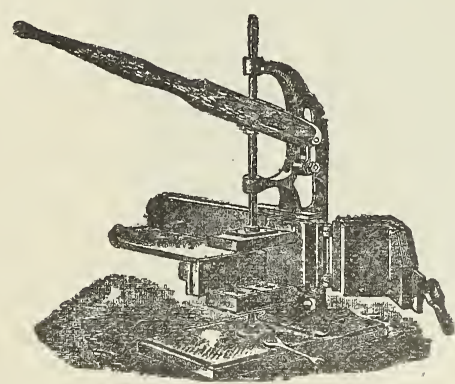

Bututer Prass,
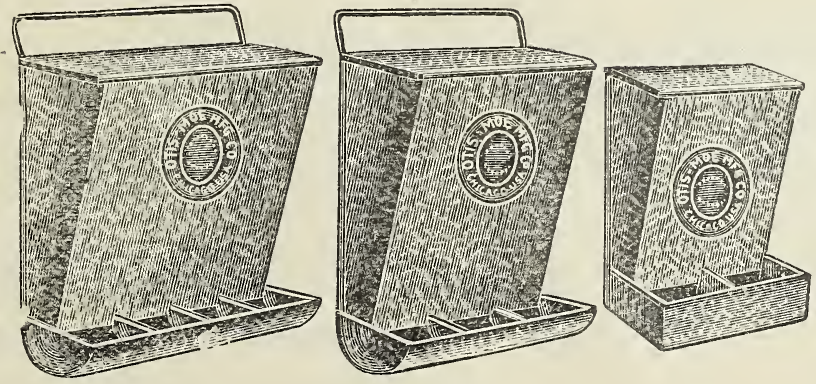

GRIT Boxriss. 


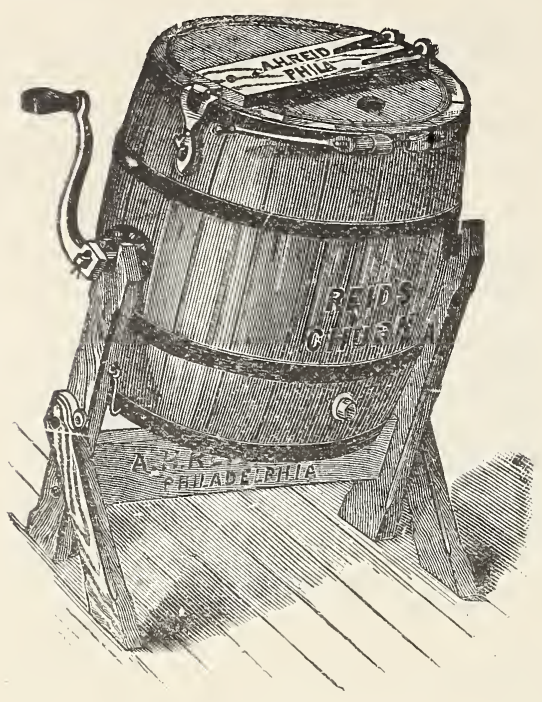

Reid's Barrel ChuRNS.

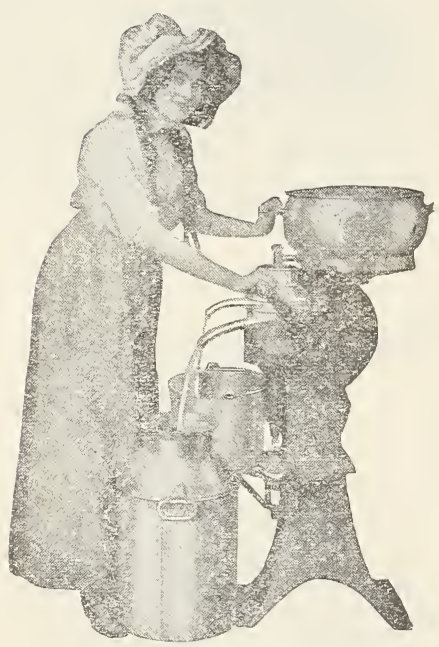

DE, Laval SEparator.

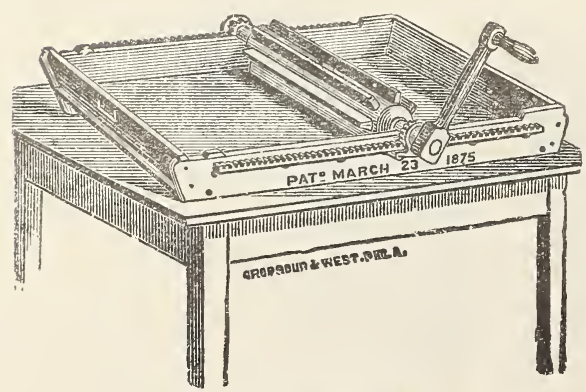

REID BUTTER WORKER.

\section{COOLERS.-Doering Root. $\$ 18.00$ to $\$ 30.00$.}

DAIRY THERMOMETERS.-All sizes and makeo thermometers and lactometers. I5c. to \$2.50.

GARGET CURE.-Per pkg., 6oc.

IRON COW STANCHIONS.-\$3.25.

WOOD COW STANCHIONS.-\$2.35.

KOW-KURE.-Two size packages. 6oc. and $\$ 1.20$.

LARD KETTLES.-35c. to \$1.00,

MEASURING KETTLES.-These are made os the best block tin, are iron clad and copper hound.

MILKING PAILS.-We have six styles of sanitary pails for you to select from. 65 c. to $\$ 4.50$.

MILK CANS (FOR SHIPPING).-Iron clad, extra heavy tin, sanitary tops, New York style. $20 \mathrm{qt}$., $\$ 7.00$; 30 qt., $\$ 8.00 ; 40$ qt., $\$ 9.00$.

MILK DIPPERS.-Various styles and sizes. r5c. to $75 \mathrm{c}$.

MEASURING STICKS.-Mention the style and size you want. $75 \mathrm{c}$. and $90 \mathrm{c}$

MILK SCALES.-Weigh $30 \mathrm{lbs}$. \$4.50.

MILKING TUBE,S. $-25 \mathrm{c}$. to 5 oc.

PHILADELPHIA STYLE LIDS (FOR LARGE CANS). -75 c. to $\$ \mathrm{r} .00$.

PAIL,S.-Heavy galvanized, ro to 16 qts. 35c. to $65 \mathrm{c}$.

PAILS.-Heavy block tin, ro to 16 qts. $45 \mathrm{c}$. to $75 \mathrm{c}$.

SANITARY LIDS (FOR LARGE CANS),-\$1.00.

SERVING KETTLES.-Block tin, iron clad, copper bound, Io qts.

SEPARATORS (DE IAVAL).-This is absolutely the best separator on the market. Do not fail to have one of these machines in your creamery.

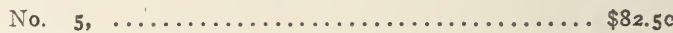

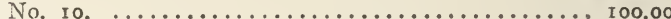

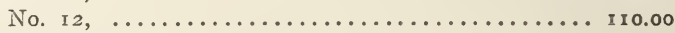

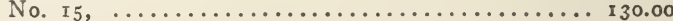

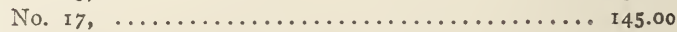

Write for catalogue.

TESTERS (THE BABCOCK MAKE),-Facile Improved Iron Frame Tester. $\$ 4.50$ to $\$ 30.00$.

We can also supply traveling outfits and all extras and supplies for above machines. Write for catalogue.

WARNER WOOD COW STANCHION.-\$2.35.

WARNER WOOD BULL, STANCHION. $-\$ 5.00$.

WATERING TROUGHS. 


\section{WASHING MACHINES The White Line Hand-Coopered Machines}

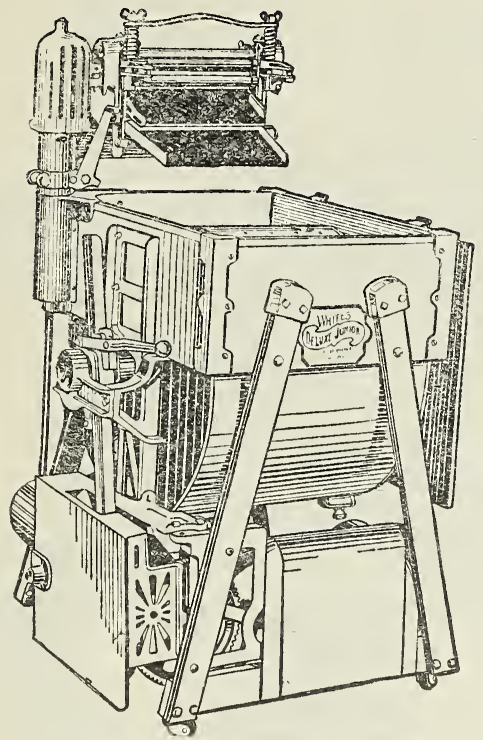

White Way Electric Washer.

iHE TWIN TUB.-This washer has two tubs wh a collapsible platform which will hold two tais or a basket. The wringer revolves over al. tubs and the working parts are all under the tubs and protected.

The White line of machines is constructed of the very best materials throughout, and when properly cared for will last many years.

WHITE WAY.-The speediest and lightest running hand-power washing machine in the world.

WHITE LILY ELECTRIC WASHER.-Operated from any electric light socket, at a cost of less than two cents per hour. Wringer and motor attached. It is a wonder.

WHITE, LILY POWER WASHER.-A machine especially built for us with an engine wringer attached; will run two ways with turn of lever. In this line we have a special outfit which it will pay you to look into.
THE WHITE WAY REVOLVING

THE WHITE WAY REVOLVING PLATFORM WASHER.-This platform revolves up to the wringer, which is reversible. This gives the use of two extra tubs. The machine does not take up much room and is very handy.

WHITE WAY PLATFORM WASHER NO. 2.-This machine consists of a large tub, which can be tipped and drained, with a platform of two extra tubs and a basket. The wringer operates over all the tubs, and can be shifted at will. It can be run in any direction, and the control is by a foot-lever. All operating parts are under the platform and easily accessible. The construction is of the finest heavy red cypress, with a minimum amount of iron or steel parts. It is absolutely the best washer on the market. Be sure to stop and see it.

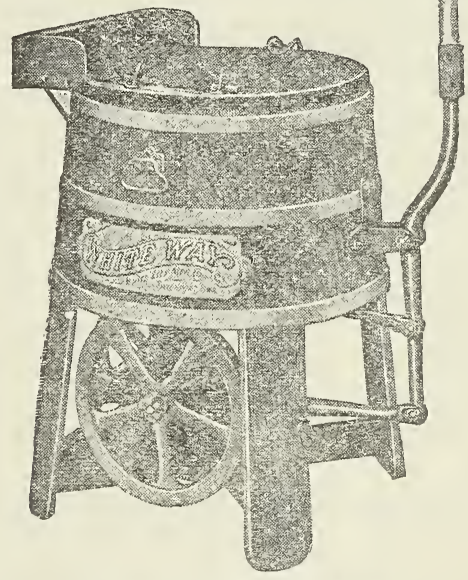

White Way Hand Washer.

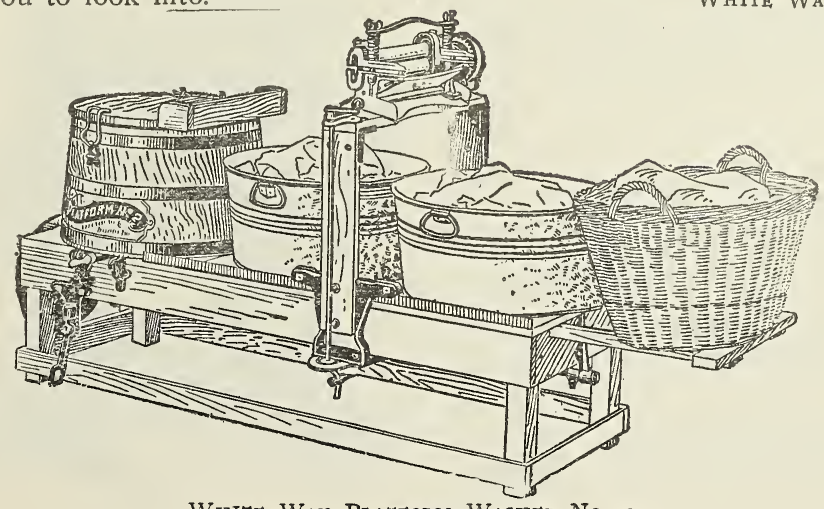

White Way Platform Washer No. 2. 


\section{General Farm Machinery LARGE TOOLS}

\section{All Large Tools are at Our Warehouse, 147 East Front Street, Directly in Rear of Store.}

No. I WHEEL BARROW.-For general farm use.

No. 3 WHEEL BARROW.-For garden use.

Ne. II STONE BARROW.-Built very strong.

No. 5 CANAL BARROW.-Fully bolted.

No. 7 CANAL, BARROW.-Fully bolted and strapped.

Nos. 16,17 and 18 BARROWS.-Steel tray for heavy and rough work around mills, furnaces, foundries, railroads and farms.

LAWN BARROW.-A large barrow for use on lawns, i mills, tanneries, livery stables, etc. Box $25^{\prime \prime} \times 32^{\prime \prime}$ $\mathrm{x} 18^{\prime \prime}$.

GREENHOUSE BARROW.-Very narrow for use in aisles. Box $4^{\prime} 8^{\prime \prime} \times 17^{\prime \prime} \times 12^{\prime \prime}$.

TUBULAR BARROW.-Dump over wheels. For ortar, coal, etc.

For any special barrow, truck or cart, write us, we can furnish it.

BINDER TWINE.-Standard make of the best material.

BROOMS.-For all purposes; house, stable, dairy, street, etc.

BOII,ERS, FARMERS'.-Cast-iron stove and caldron. Three sizes. 22 gal., $\$ 30.00 ; 30$ gal., $\$ 37.50$.

Also THE "FARMERS' FAVORITE" FEED COOKER AND AGRICULTURAL BOILER.-These oookers complete with stove, fire-box, galvanized steel boiler with four handles and cover, one length of $6^{\prime \prime}$ stovepipe and one 6" elbow; from 25 to roo gal.; $\$ 20.00$ to $\$ 30.00$.

25 Gal., $30 \mathrm{Gal}$., $40 \mathrm{Gal}$.

A fine stove for heating water for washing. Burns wood or corn cobs.

CORN SHELLERS.-No. 2, without cob separator, capacity, 125 bu. per day. No. 3, with cob separator epacity, 125 bu. per day. No. 4, with cob separator o sieve, capacity, I/5 bu. per day. No. 7, separates $c o b$ and chaff. Two hopper, hand or power, capacity, 200 to 600 bu. per day. No. 8, unexcelled, like No. 7 , for farm and warehouse use.

CIDER MILLS.-Our line of Keystone mills is unsurpassed. Made of the finest wood, all iron, braced and trapped. Ranging from No. o to Senior in size. Prices frem $\$ 4.50$ to $\$ 28.00$.

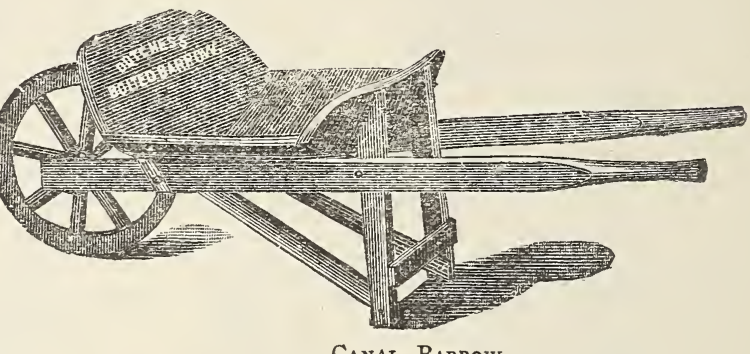

Canal, Barrow.

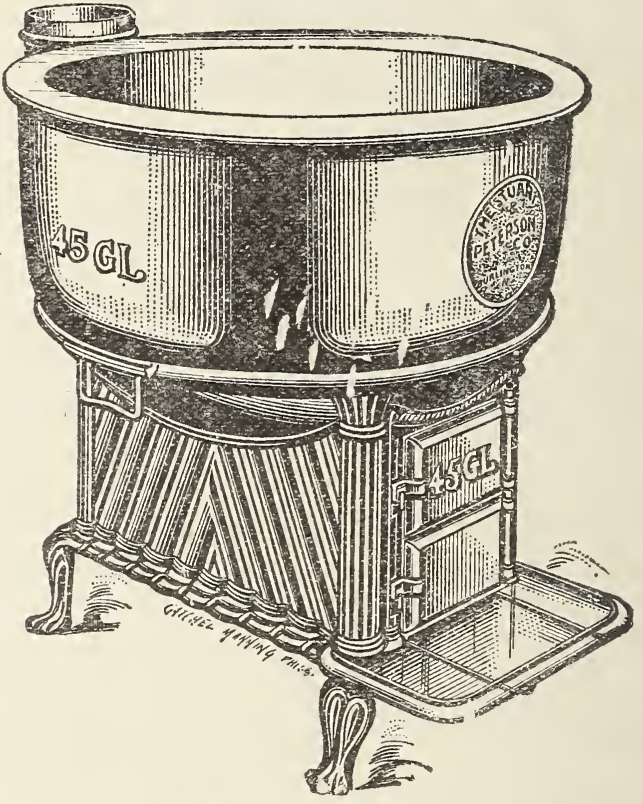

FARMER'S BOILER.

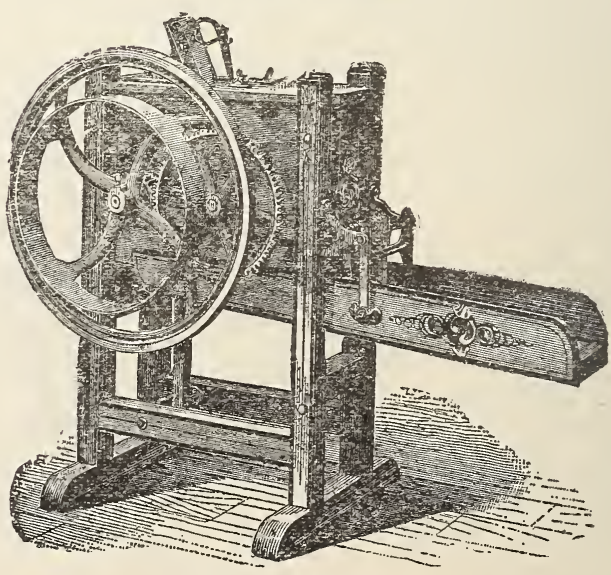

CORN S'HELLER, 


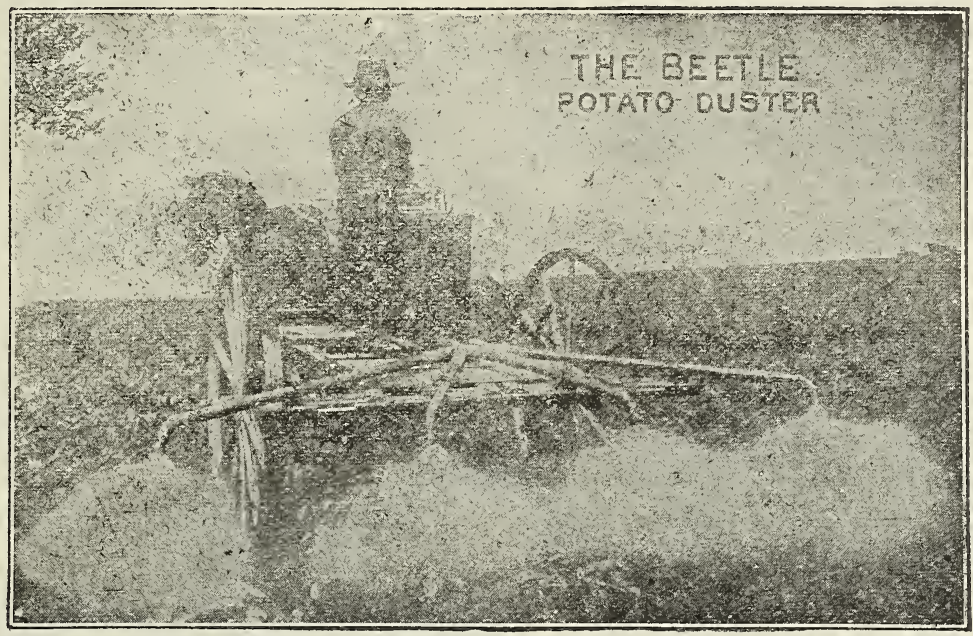

BEETLE DUSTER.

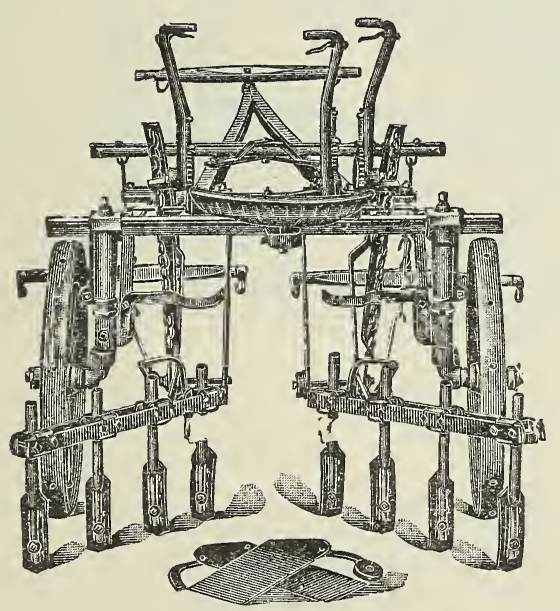

CORN PLANTERS.-The Black Hawk and C. B. \& Q. Absolutely the best planters on the market. Single or double row, one or two horse, check or drill, fertilizer attachment and high or low wheel.

The C. B. \& Q. Corn Planter has been added to the famous Ribsam line of Farm Machinery. This Planter is one of the very latest in Corn Planters. It will be worth your spending a little time in examining it at our ware rooms. Made in both styles, drill and to check in hills.

Write for catalogue.

Bil Ficks and other planters.
CORN BINDER AND HARVESTER.-The McCormick will handle corn under all conditions. Has an accurate knotter and practical bundle carrier. Will operate in almost any corn field.

CULTIVATOR, RIDING.-The "Famous Ohio" pivot axle and balance frame. No weight on horse's neck or sudden dumping. For use in any kind of vegetables. Can be narrowed to $26^{\prime \prime}$, and widened to $58^{\prime \prime}$.

"Iron Age." Fixed wheel, a very fine machine for the gardener.

CLOD CRUSHERS.-Single or double. It breaks and pulverizes hard and lumpy soil and leaves it loose in narrow ridges. A wonder for increasing crops.

DRILIS.-The "Ontario" is the simplest constructed, lightest of draft and has the best force feeds of any drill on the market. Either hoe or disc furrowers.

DUSTER BEETLE.-Always ready for use, can be operated by an inexperienced person. Furnished with cart and covers four rows.

DIRT OR DRAG SCOOPS.-Made of high carbon special scraper steel, securely riveted; it works perfectly. Equipped with heavy steel bail, hooks, sockets and perfectly working swivel. Our line of scoops unsurpassed. 
HAY CARS.-The Ney car is the lighteat draft for carrier ever made. Carries pulley close to track and travelers cover large track surface.

HAY RACKS.-Corner and side-racks, cast-iron, steel and wire, mangers and stall partitions.

HIAY FORKS.-We carry the Harris and Nellis single barpoon forks, Farrel grapple fork and Ney Slings. We can supply your every want.

HAY IOADERS.-The Emerson is the best. We stand back of it.

ENGINES.-The International engine is the very best value for money paid. One of the highest grade and most durable engines in existence.

The United engine leads in low price and high quality. It has no equal as a chore engine.

Do not fail to consult us before placing your order.

FANNING MILLS.-Our mill is above re proach. It will clean any kind of seed, small or large.

FODDER CUTTERS.-The "Ohio" line is the best in existence. Frames made of the best of hard wood, securely constructed. Knives of the best steel, finely tempered. We carry all styles of cutters, blowers and shredders.

Our "Peerless" shredder is a revelation. This machine does wonderful work. Let us demonstrate it to you.

FURROWING SLEDS.-Used by truckers for marking out corn, potato and other vegetable patches.

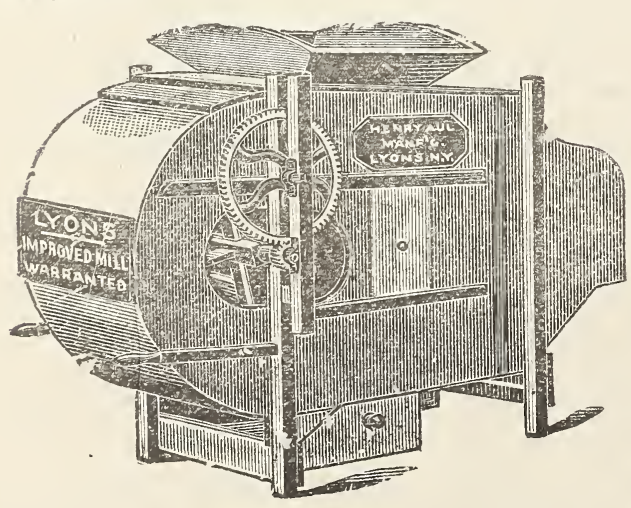

FARMING MILI.
FEED CUTTERS.-The Handy, Triumph and Ohio feed cutters, from $\$ 4.50$ upward.

\section{GREEN BONE CUTTERS.-When you buy a}

"Mann" New Model, you buy a machine which you will keep. You can try it before you buy it.

GRIND STONES.-Our line is the best in the market. Hand and power machines from 2 to $240 \mathrm{lbs}$. Stones are movable on frames to suit operator. Journals are ballbearing, making easy running and frictionless machinea.

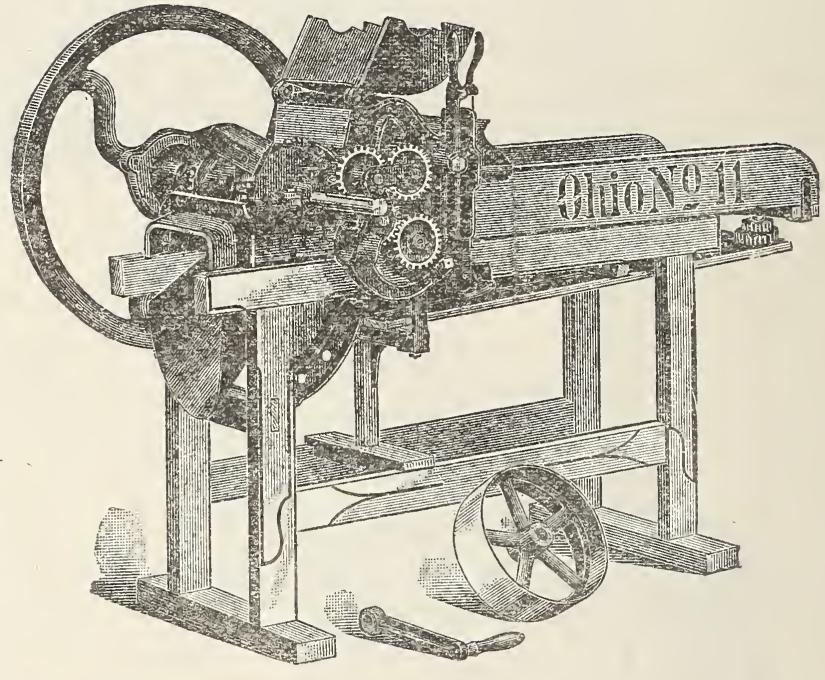

OHIO FODDER CUTTER.

FEED MILLS.-The "Peerless Mill" grinds corn on the cob and grain. It is fitted with wooden pin breaks, sectional plates, quick release and needs no friction clutch to start it. It is the latest addition in the feed mill family.

The "Peerless" Feed Mills are, without exception, the "Best" mills made. They are built with cast-steel "cut" plates and are the only mills that will grind cob meal or other grains in any condition, wet or dry. They are the most successful mills for grinding oat for chicken feeding. Made in all sizes, suitable for $1 \% / 2$ to 20 horsepower engines. 
HARROWS.-Double and single disc, star and orchard disc harrows, spike tooth harrows in steel and wood, with closed and open frame, also spring tooth and Acme harrows. Ask for particulars and catalogue.

Our light draft orchard extension harrows are the newest thing for the orchard. Call and see them.

HOG TROUGHS.-Cast-iron and steel hog, horse and poultry troughs, combining strength, cleanliness, utility and long-lasting qualities. You should have one.

HOISTS.-The Farrell double-drum hoist, the best hoist for the farmer.

HOG SCALDERS.-Made of the best galvanized iron with steel fire-box. Have improved swinging rack, with ratchets to hold it where desired. $\$ 45.00$ to $\$ 60.00$.

HITCHING POSTS.-Our line consists of wood, iron, galvanized and steel posts.

LADDERS.-Straight and extension ladders. Step ladders and adjustable scaffolding jacks. Extensions fitted up with bale or locks. Fruit and window ladders. All ladders made of the best materials, with wood free of knots.

LIME SPREADERS.-The Ontario is positively the best. It has unmistakably made good. The Ontario Broadcaster and Rower is without an equal. It is the only force-feed machine of its kind made.

MANURE SPREADERS.-The Emerson-Brantingham, No Wide Spread Manure Spreader we believe is the best and lightest diaft spreader made.

MOWERS.-The McCormick new 4-mower is the simplest mower made, has less parts than any other mower. It is light in draft and very durable and has direct stroke pitman.

MANGERS.-All kinds of steel and cast-iron corner and side mangers.

NAILS.-In any quantity, style or size, by the pound or keg. Staples and caps of all kinds. Also flat head roofing nails.

OAT FORKS.-The handiest thing for handling oats. Made of the best of wood.

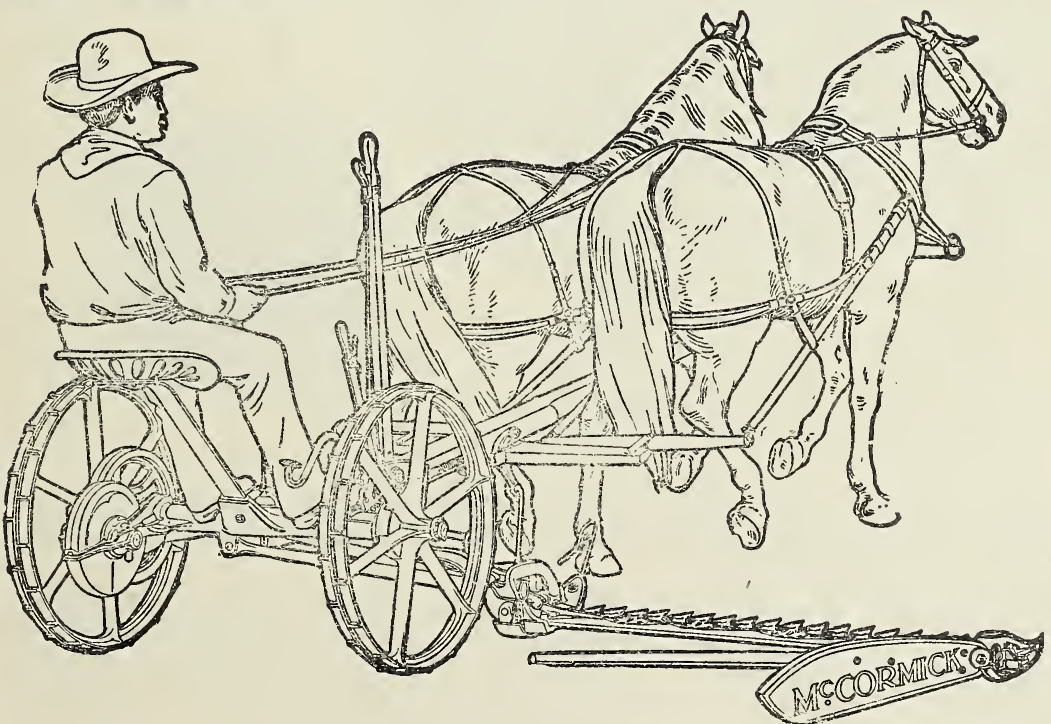

POTATO CUTTER.-The Eureka has the greatest capacity; cuts uniform size, prevents waste, reduces cost It will cut a bushel of seed in five minutes.

PUSH CARTS.- Of the best construction, in all sizes. Heavily braced and riveted, with wood or steel wheela Ask for catalogue.

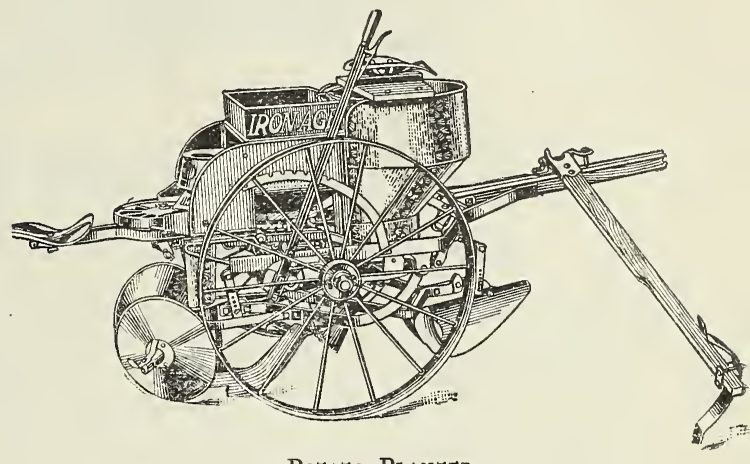

Potato Planter.

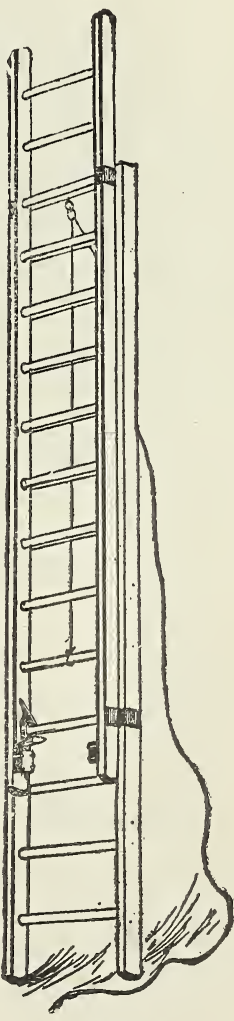

Laddeı 


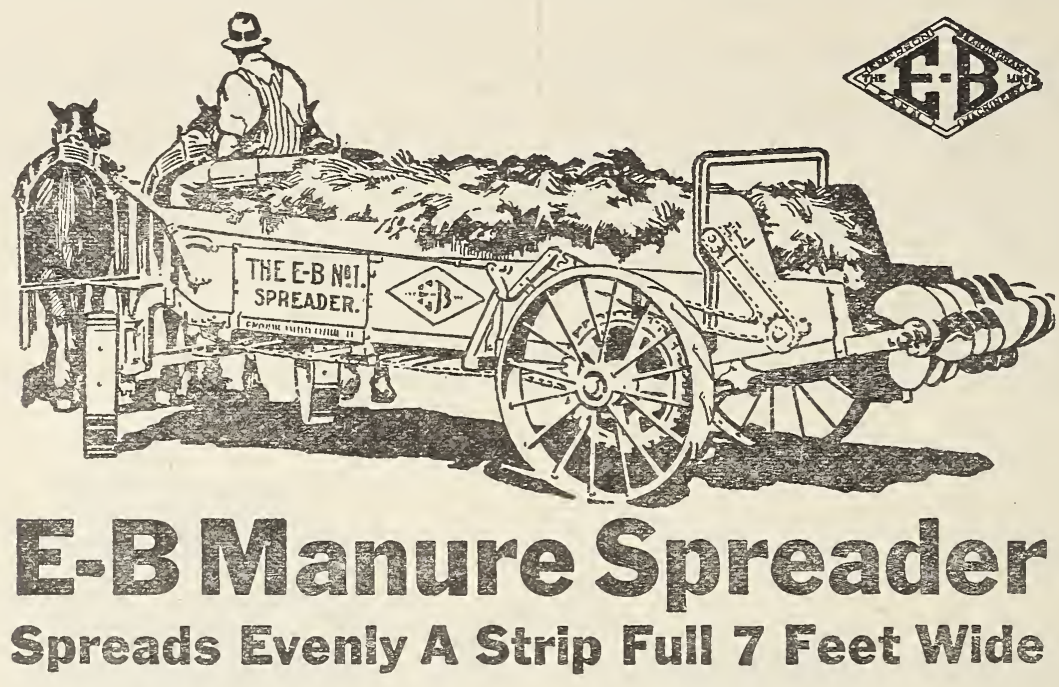
TWO tons of manure applied with this spreader 1 has the efficiency of three tons spread with a fork. Every farmer in this locality will be interested in this machine. The E-B Spreader is built low down-easy to load-easy to pull. Water-tight bed holds liquid in manure. Drives through a $6 \mathrm{ft}$. door. Double steel beater with 102 chisel pointed steel teeth and 18 wide spread steel blades thoroughly shred and evenily spread in most available plant food form. Wheels track. Turns square corner. Weight only 1800 pounds. 55 to 70 bushels capacity-only $3 \mathrm{ft} .5$ in. from ground to ton of box. Glad to talk spreaders with you. Come in and see us.

\section{PITTSBURO PERFECT ELECTRICALLY WELDED FENCES THE WELD THAT HELD}
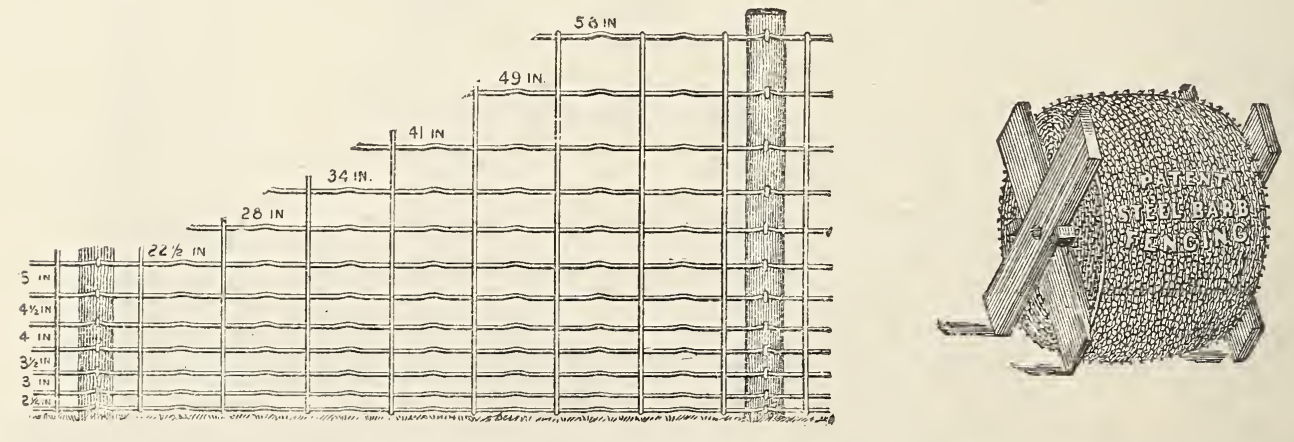

\section{FARM FENCE JUMBO FENCE CHICKEN FENCE LAWN FENCE SHEEP FENCE HOG FENCE GARDEN FENCE BARBANDPLAIN CATTLE FENCE RABBIT FENCE WIRE}

Remember that all "PITTSBURG PERFECT" Fences are now made of the new "DOUBLE GALVANIZED" wire, which adds YEARS OF LIFE to them.

Remember that all "PITTSBURG PERFECT" fences have stay wires as heavy as intermediate line wires. A fence is only as strong as its lightest wire.

No wire projects to injure stock or pull wool of sheep.

Possesses the strongest fence joint in the world. Where wires are welded together by electricity, the fence is twice as strong as the wire itself.

Guaranteed stronger and more durable than any other. Guaranteed that the wire is not injured at the joints. wire.

We can supply you with any style or size fence from Our Warehouse,

MARTIN C. RIBSAM. 


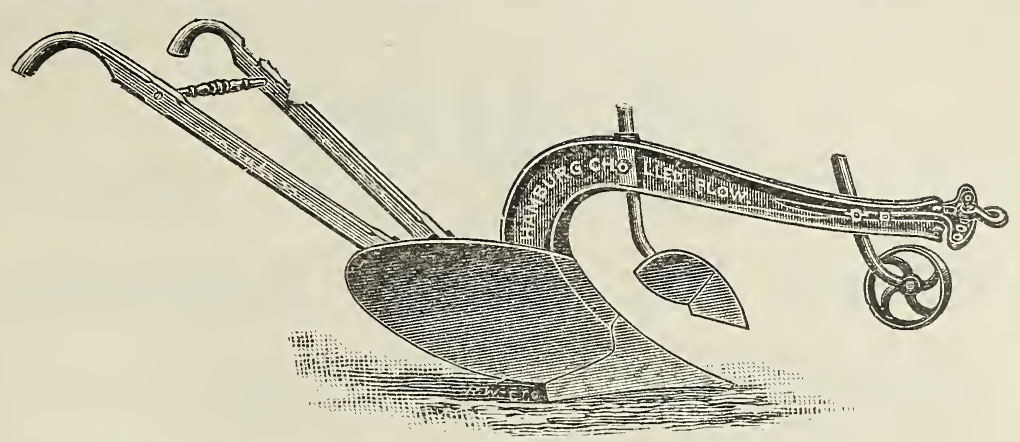

PLOWS.-You cannot help being satisfied when you examine our line. The different makes can be seen at our warehouse, on East Front Street, in all styles.

Syracuse, South Bend, Wiard, Bissel and Boss. Vineyard, and Rooter plows. Pilot and New Casaday Sulky plows. South Bend and Chicopee Two-way plow's. Spaulding Deep Tilling plow, Subsoil and Chicopee Two-way plow's. Spaulding Deep Tilling plow, Subsoil
plows, also subsoil attachments and sweet potato plows. We carry in
stock extras for any plow.

POTATO PLANTERS.- "Eureka," with or without fertilizer at. tachment. The most perfect planter on the market. Light weight and draft. Main frame all steel; one-man control.

"Aspinwall." The planter for you. A one-man machine doing easy, perfect and profitable work. Also Robbin planters.

POTATO SORTERS. - In several makes. We can satisfy you. Aspinwall, Snook, etc.

POTATO DIGGERS. - Our line consists of a selection from a collection of the best. The Hoover, Little Giant. Iron Age, Hallock and Planet, Jr.

ROLIERS.-The "Fa. mous Ohio" and "Buchs" makes in steel and wood, two or three sections. Do not miss seeing our new all steel flexible frame roller, it's a dandy.

REA PER S AND BINDERS.-The "McCormick" is simple, dependable, light of draft and easy to operate. It cannot be beat. Let us demonstrate it to you.

RAKES.-We can sell you an Emerson, Osborne or Champion Rake, with self, foot and hand dump. They are durable and easy to operate.

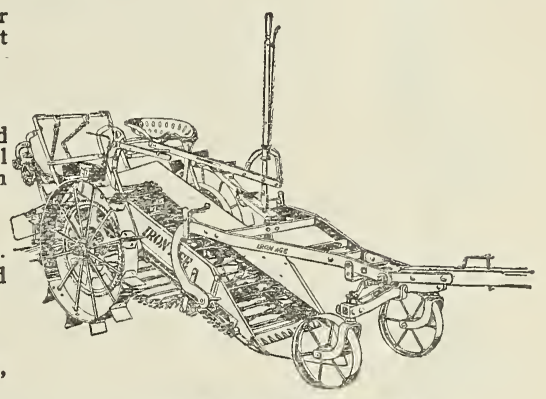

Hoover Porato Digerar.

The Emerson Side Delivery is unsurpassed. Look it over.

ROOT CUTTERS.-Our "Banner" line is complete. Machines for hand and power. These machines are of the highest value to the stock raiser. Our No. 30 will cut the root 1,800 times and cut out from $I \frac{1}{2}$ to 2 bushels of cut feed per minute by hand.

The "Buchs" cutter is an excellent machine, feeds itself and cannot choke or clog.

ROPE.-In all sizes in cotton, jute, manilla and hemp. Garden line, twine and tape

TRUCKS.-For bags, barrels and all purposes, with any style foot. We can supply your every want.

WIRE STRETCHERS.-The "Veribest," Wilcox, Ney and Hall stretchers.
Ontario Grain Drili.

SAWS.-Saws mounted or unmounted, with or with. out frames.

No. 4 , Cross-cut Circular Saw, Blade $18^{\prime \prime}$ to $34^{\prime \prime}$.

No. 5 , Cross-cut Circular Saw, Blade $22^{\prime \prime}$ to $30^{\prime \prime}$.

No. 3 , Cross-cut Circular Saw, Blade $22^{\prime \prime}$ to $30^{\prime \prime}$.

One and two-man cross-cut and log saws.

STRAWBERRY BOXES.-Quart and pint standard boxes, made of the best material with tight corners.

SPRINGS.-For wagons and all purposes, single and double, with or without braces.

SEEDERS. - "The Thompson." The original and only successful wheelbarrow grass seeder. It will sow any kind of grass seed. Cahoon and other hand seeders.

STUB CUTTERS.-Our Newkirk cutter is the only cutter on the market which will do satisfactory work. 


\section{PUMPS}

\section{Pumps for Every Purpose}

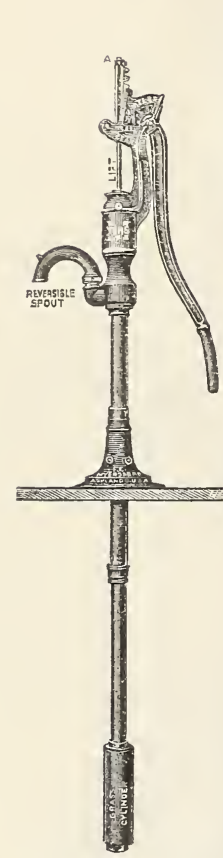

PUMPS.-A full line of Myers' Well Pumps. Tank and suction pumps, including pumping jacks of various styles. Leathers and cylinders.

Pitcher Pumps, Iron and Brass Lined, ...............\$2.00 to \$5.00

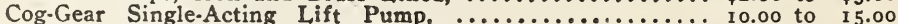

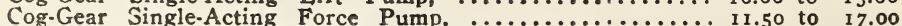

Pneumatic cog-gear double-acting anti-freezing force pump,...

Myers' Cog Tank Pump, according to capacity, ........... 10.00 to 20.00

Myers' Eingle-Acting Three-Way Force Pump, Anti-freezing, I 5.00 to 20.00

Extra heavy pump stands with stop cock spout, .......... I0.00 to 15.00

Cucumber pumps, plain and porcelain lined.

Pumps for Pneumatic Air Compression Water Systems. All styles for any purpose. A full line of well points for.driven wells, caps, couplings and pipe.

All kinds of Pumps for Spraying and Spraying Apparatus. When in need of a water system for the Home or Stable

\section{Consult RIBSAM}

Water systems and all necessities for the home or stable. Hydro=Pneu= matic Pumps and Pressure Pumps

DEEP WEIT PUY P.

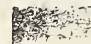

DO NOT FAIL TO ASK W: FOR ESTIMATES

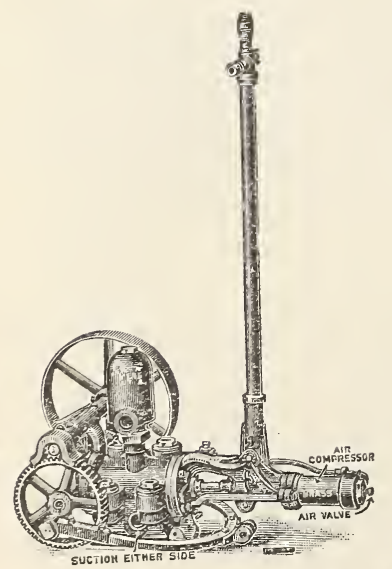

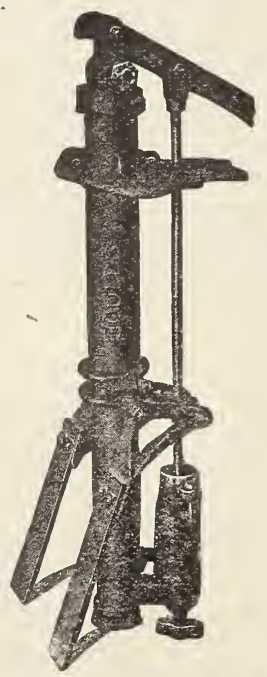
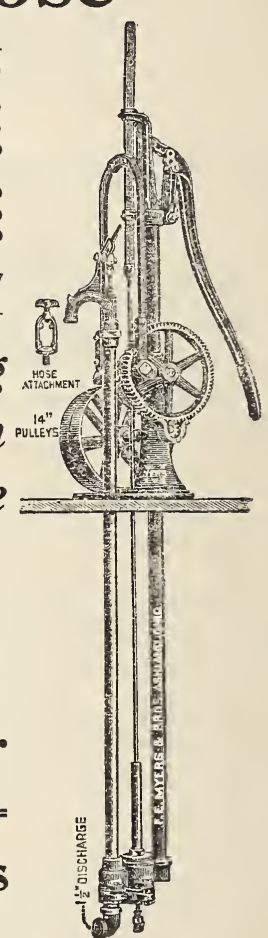

THREE-WAY PUMP AND JACK.

\section{Martin C. Ribsam}

Warehouse-147 E. Front St.

Store-S. Broad and Front Sts.

TRENTON, NEW JERSEY 


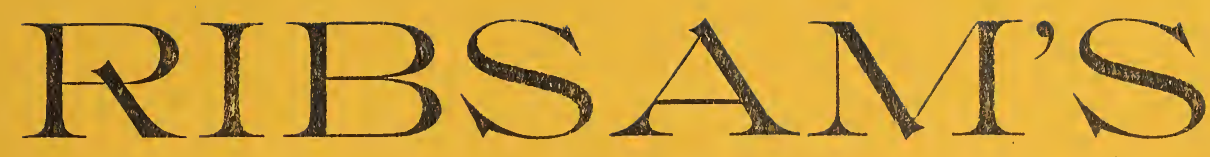

\section{High-(irade FERTILIZERS}

Special Prices on Application on Two=Ton Lots and Upward

Prices subject to market variations.

PURE GROUND BONE.-This is strictly a bone fertilizer. 6c. per lb.; 25 lbs. $\$ 1.00 ; \$ 3.75$ per roo $1 \mathrm{bs}$; $\$ 57.50$ per ton. $4-(23)$.

HIGH-GRADE TRUCK AND CABBAGE FERTILIZER.-Especially for rushing a vegetable crop. $6 \mathrm{c}$. per $1 \mathrm{~b}$.; 25 lbs. $\$ 1.00 ;$ I 00 lbs. $\$ 3.75 ; \$ 63.50$ per ton. 8-8.5.

TOP DRESS'ING FOR ASPARAGUS AND GRASS.-Especially for rushing a hay crop. 6c. per lb.; 25 lbs. $\$ 1.00 ; \$ 3.75$ per roo lbs.; $\$ 47.00$ per ton.

FARMERS' HIGH-GRADE POTATO FERTILIZER.-Very highly endorsed by potato growers. 6c. per Ib. 25 lbs. \$I,00; $\$ 3.75$ per roo lbs.; \$49.00 per ton. 4-8-6.

CORN AND SWEET POTATO FERTILIZER.-6c. per 1b.; 25 lbs. \$1.00; \$3.0o per roo lbs.; \$38.50 per ton. 2-8-5.

SPECIAL CORN MIXTURE.-6c. per 1b.; 25 1bs., \$1.00; \$3.00 per Ioo lbs.; \$37.50 per ton. 2-10-2.

SPECIAL GRAIN FERTILIZER.-6c. per lb.; 25 lbs., \$1.00; \$3.00 per Ioo lbs.; \$33.00 per ton. I-8-3.

STEAM BONE.-A good, quick-acting fertilizer with long duration in soil. 6c. per lb.; $251 \mathrm{lbs}$. $\$ 1.00 ; \$ 3.50$ per I 00 lbs.; $\$ 52.50$ per ton. $3-(23)$.

GRANULATED BONE.-This is moderately fine and adapted for high fertilizing purposes. This bone is of very fine quality. 8c. per lb.; $\$ 4.50$ per roo lbs.; $\$ 65.00$ per ton.

FOOD FOR FLOWERS.-A fertilizer made especially for flowers. It is almost free from odor and clean to handle. It produces a healthy luxurious growth and induces early and profuse flowering. A book on Treatment of Plants and Directions for use of Food given with every box of food. Small pkg., 2oc.; large pkg., $35 \mathrm{c}$; ; sufficient for 15 plants per year.

LIME.-Pure ground stone lime. Especially adapted for lawn dressing, it takes the sourness out of the soil and makes a beautiful green sward. Io lb. bag $25 \mathrm{c}$.; 25 lbs. $40 \mathrm{c}$; ; 50 lbs. $65 \mathrm{c}$; ; $100 \mathrm{lbs}$. $\$ 1.00$.

LIMOID HYDRATED.-For vegetable garden and lawn. 1o lbs. spread 10 x 10; 10o lbs. $20 \times 50$. Prices, Io $1 \mathrm{~b}$ bag $25 \mathrm{c}$; $25 \mathrm{lb}$. bag 50c.; $50 \mathrm{lb}$. bag $75 \mathrm{c}$; ; $100 \mathrm{lb}$. bag, $\$ 1.25$.

WOOD ASHES.-Pure ashes; fine for top dressing for clover lawn; no adulteration. \$2.75 per I00 $1 \mathrm{bs}$.; $\$ 35.00$ per ton.

SHEEP MANURE.-One of the best fertilizers for aiding the growth of plants. $6 \mathrm{c}$. per $1 \mathrm{~b} . ; 251 \mathrm{bs}$. \$1.00; $\$ 3.25$ per roo lbs.; $\$ 50.00$ per ton.

Inoculate Your Alfalfa, Clovers, Cow Peas, Soy Beans, Vetches and all other legume crops with

\section{Mulford}

Small Cost

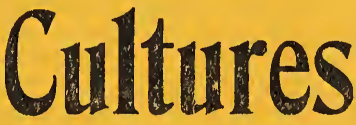

Easy to Use

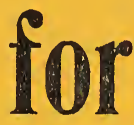

Legumes

MULFORD CULTURES contain pure, tested strains of active, vigorous nitrogen-fixing bacteria, for inoculating seeds of legumes or soil.

MULFORD CULTURES are scientifically prepared and tested with the utmost care and skill. Enormous numbers of these very valuable and desirable bacteria are thus available to you in every package of Mulford Culture and may readily be applied to your seed. The sealed bottle insures purity.

LEGUMES OFFER THE BEST-KNOWN MEANS of maintaining soil fertility and rejuvenating overcropped and worn-out fields. They add both humus and nitrogen to your soil and thus increase your yield of wheat, cotton, corn and other non-legume crops.

THE U. S. DEPARTMENT OF AGRICULTURE and many State Agricultural Experiment Stations reoommend inoculation of legumes with nitrogen-fixing bacteria to induce a prompt "catch" and increase yous yield.

MULFORD CULTURES are prepared for:

$\begin{array}{ll}\text { ALFALFA } & \text { ALSIKE CLOVER } \\ \text { CRIMSON CLOVER } & \text { BURR CLOVER } \\ \text { SWEET CLOVER } & \text { COW PEAS } \\ \text { RED CLOVER } & \text { SOY BEANS } \\ & \text { PEANUTS }\end{array}$

\section{VETCH \\ VELVET BEANS \\ SWEET PEAS}

GARDEN PEAS

\section{IIMA BEANS \\ LESPEDEZA \\ BEGGAR WEED \\ and others}

Always specify on your order what crop you want to inoculate, as there is a different strain of bacteria for each legume.

PRICES-5-Acre Size, \$5.00 (Dollar per Acre); I-Acre Size, \$1.50; 1/4-Acre Size, \$0.75. Small size (supplied only in four varieties, for Garden Peas, Garden Beans, Lima Beans and Sweet Peas), \$0.35.

These Prices include delivery on freight shipments. Free Descriptive Folder Sent Upon Request.

\section{MARTIN C. RIBSAM, Trenton, N. J.}




\section{Say It With Flowers}

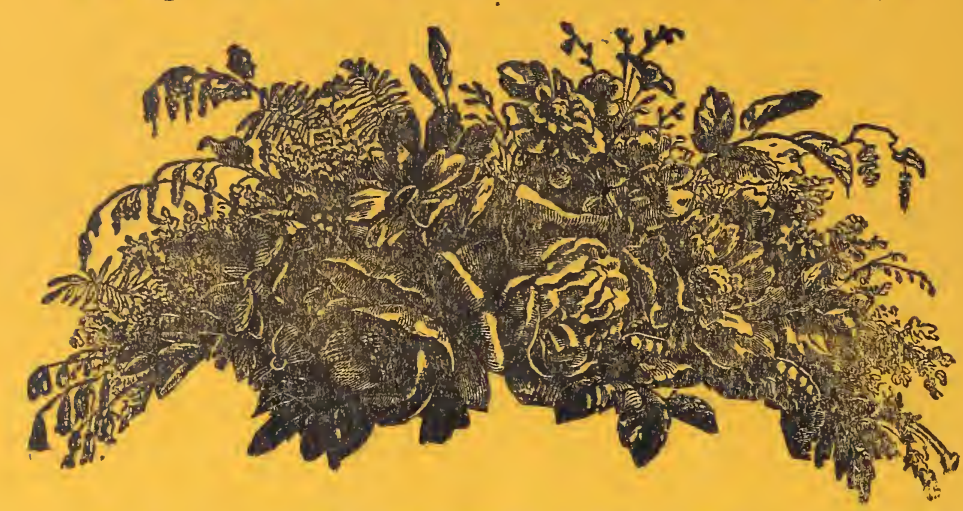

Flowers will dellver your message anywhere in the world for any occasion. They carry the message so beautifully that they tell the story themselves.

FLOWERS DELIVERED TO ANY PART OF THE WORLD THROUGH OUR FLORIST TELEPHONE AND TELEGRAPH SYSTEM.

\section{MY CUT FLOWER SERVICE}

is growing, which is evidence that others think it is good. I am trying to do all that is pos slble to make this part of my business more satisfactory, If that can be done.

My facilltles for securing the finest flowers which grow in this part of the country are unsurpassed. I draw from many sources, from each securing those blooms whlch seem to be the best grown there.

\section{FLOWERS FOR SOCIAL FUNCTIONS.}

receive my personal attention, as do also funeral designs, of which my establishment shows a satisfactory variety. When anything special is needed, I can get that, too, and very promptly.

Speclal deslgns can be secured here for every possible occasion, and the service ls as accommodating as it is complete.

\section{AS TO CHARGES}

In larger cities no florlst thinks of asking as little as I do. I make the charges as moderate as it is posslble to make them. A falr profit is all that is desired, and a fair compensation for labor. It also.

Prices depend entirely upon what is wanted; the time of the year has much to do with

YOUR ORDERS ARE SOLICITED upon the broad basis of merit, and I respectfully ask their continuance, pledging continued attention to your wants and my best efforts to please.
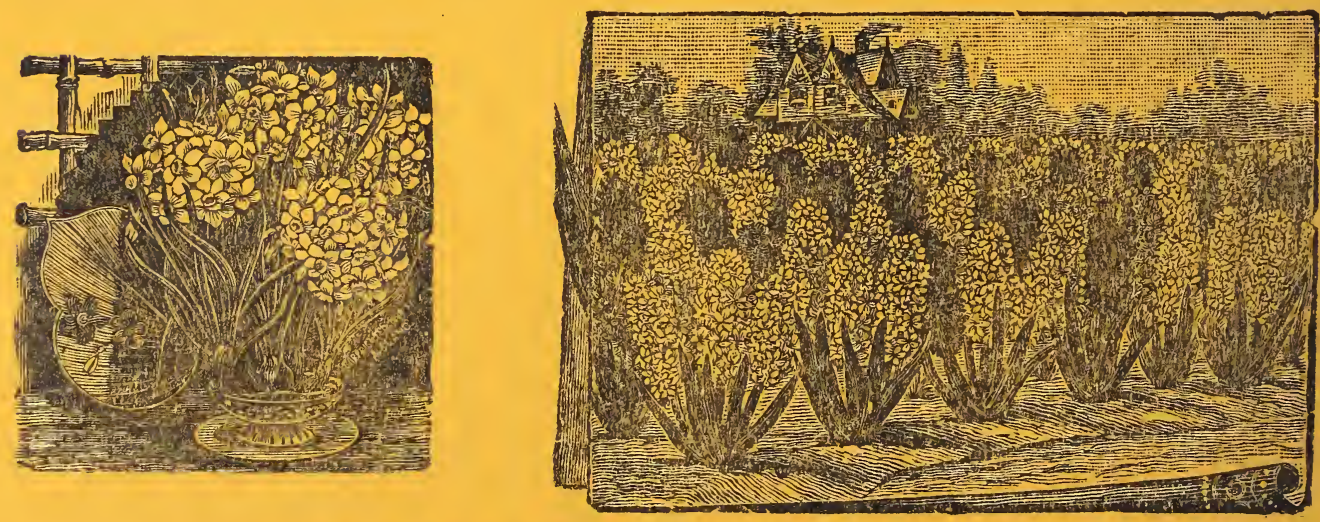

\section{MARTIN C. RIBSAM}

Corner Broad and Front Streets, Trenton, N. J. 